\title{
Peningkatan Hasil Belajar Akuntansi Keuangan Melalui Model Cooperative Learning Tipe Jigsaw
}

\begin{abstract}
Warneri*
Abstract: This research aimed is toimproving the students' learning achievement and activities through improving accounting learning process by implementing jigsaw type cooperative learning model.Using action research method, this research was done through planning, implementation, observation and reflection. This action research was conducted in two cycles. Every cycle was done in eight metings. The data of learning achievement were collected through materials comprehension test before the action, after the first cycle action, after the second cycle action, and after all actions had been completed. The data of the students' activities were collected through observations during the teaching and learning processes were administered. The research resulted in the improvement of learning achievement and activities in the process of learning accounting through the implementation of jigsaw type cooperative learning model.
\end{abstract}

Keywords: Learning Achievement,Financial Accounting,Cooperative Learning, Jigsaw Type

Abstrak: Tujuan penelitian ini adalah untuk meningkatkan hasil belajar dan aktivitas belajar siswa dengan cara memperbaiki proses pembelajaran akuntansi dengan menerapkan model pembelajaran kooperatif tipe jigsaw di kelas XI IPS SMA Negeri 1 Bengkayang Kalimantan Barat.Metode penelitian yang digunakan adalah penelitian tindakan dengan alur perencanaan, pelaksanaan, observasi dan refleksi. Penelitian tindakan ini dilaksanakan 2 siklus, setiap siklus dilaksanakan 8 kali pertemuan.Data hasil belajar diperoleh melalui tes pemahaman materi sebelum pelaksanaan tindakan, setelah tindakan siklus 1, setelah tindakan siklus 2 dan setelah pelaksanaan tindakan berakhir. Data keaktifan belajar siswa diperoleh melalui pengamatan pada saat proses belajar mengajar berlangsung. Hasil penelitian diperoleh bahwa terjadi peningkatan hasil belajar dan aktivitas belajar siswa dalam proses pembelajaran akuntansi dengan menerapkan model pembelajaran kooperatif tipe jigsaw.

Kata kunci: Hasil Belajar Akuntansi Keuangan dan Model Pembelajaran Kooperatif Tipe Jigsaw

\section{PENDAHULUAN}

Hasil wawancara dan observasi terhadap guru dan peserta didik diperoleh informasi bahwa masih terdapat guru akuntansi dalam melaksanakan proses pembelajaran selalu menggunakan pendekatan konvensional, guru masih berperan sebagai pusat proses belajar, guru mengetahui ragam metode, model dan strategi dalam pembelajaran tapi tidak mempunyai keberanian untuk memulai dengan hal tersebut. Demikian pula dengan sumber pendukung dalam pembelajaran akuntansi seperti media,bahan ajardan lembar kerja siswa belum dimanfaatkan secara optimal. Di samping hal tersebut pada dasarnya guru juga kurang memperhatikan aspek sosial dalam proses pembelajaran, karena masalah waktu yang terbatas dan penilaian hasil belajar sebagian besar hanya dinilai berdasarkan kemampuan peserta didik menyelesaikan soal-soal yang diberikan. Sebagian besar peserta didik beranggapan bahwa mata pelajaran akuntansi keuangan adalah pelajaran yang tergolong sulit dan susah untuk dipahami, rumit dalam arti kata

* Warneri, FKIP Universitas Tanjungpura Pontianak, Jalan Prof. Dr. Hadari Nawawi Pontianak Telepon 081345440189,Email :warner.6369@yahoo.co,id 
wacana bagi dosen pengampu mata kuliah dapat menyusun bahan ajar yang lebih inovatif dan kreatif.

Bagi peneliti lain, hasil penelitian ini diharapkan menjadi acuan untuk mengadakan penelitian lebih lanjut dengan memperbaiki kelemahan yang ada agar lebih baik lagi terhadap hasil penelitian.

\section{KESIMPULAN}

Modul yang dikembangkan sesuai dengan kebutuhan mahasiswa Sekolah Tinggi Ilmu Tarbiyah dalam mempelajari mata kuliah Sejarah Pendidikan Islam dilihat dari segi isi, Penyajian, Bahasa dan Kegrafikan hal ini dibuktikan dengan penilaian yang rata-rata sangat baik.

Diperoleh kesimpulan hasil uji validitas bahwa penggunaan modul Sejarah Pendidikan Islam mampu meningkatkan hasil belajar pada mata kuliah Sejarah Pendidikan Islam atau dapat dikatakan terdapat hubungan yang signifikan terhadap hasil belajar sebelum menggunakan modul dan sesudah menggunakan modul baik dengan model mandiri maupun konvensional.

Modul yang dikembangkan memiliki kelebihan diantaranya bahwa modul yang dirancang tidak hanya digunakan secara mandiri tetapi juga secara konvensional atau dengan kehadiran dosen yang membimbingnya. Hal ini berdampak pada pola belajar mahasiswa, yaitu mahasiswa dapat belajar menurut kecepatan masing-masing tidak terpaku pada apa yang disampaikan oleh dosen pengampu.

Hasil penelitian ini menghasilkan modul cetak yang dirancang sesuai kebutuhan mahasiswa, tetapi memiliki kelemahan diantaranya karena bentuknya cetak yang terbuat dari kertas maka modul ini tidak tahan pada air menjadikan mudah rusak.

\section{DAFTAR RUJUKAN}

Harlock, Elizabeth. Psikologi Perkembangan Suatu Pendekatan Sepanjang Rentang kehidupan edisi V. Jakarta: Erlangga, 2006.

Majid, Abdul., (Perencanaan Pembelajaran Mengembangkan standar Kompetensi Guru, Bandung : Remaja Rosdakarya, 2011.

Miarso, Yusufhadi. Menyemai Benih Teknologi Pendidikan. Jakarta: Prenada Media Group, 2011.

Muslich, Masnur.Text Book Writing Dasar- dasar Pemahaman, Penulisan dan Pemakaian Buku
Teks, Jogjakarta : AR Ruzz Media, 2010.

Nasution, Berbagai pendekatan dalam proses belajar mengajar. Jakarta: Bumi Aksara, 2008.

Prastowo, Andi, Panduan Kreatif Membuat Bahan Ajar Inovatif. Yogyakarta: Diva Press, 2011.

Purwanto, Aristo Rahadi, Suharto Lasmono. Pengembangan Modul. Jakarta: Pustekkom, 2007.

Sitepu, B.P. Penyusunan Buku Pelajaran. Jakarta : Verbum Publising,2006.

Sitepu, B.P. Penulisan Buku Teks Pelajaran,Bandung: Remaja Rosdakarya,2012.

Smaldino, Sharon E.,Deborah L. Lowther, dan James D. Russell. Instructional Technology \& Media for learning"Teknologi Pembelajaran dan Media untuk Belajar", terjemahan Arif Rahman.Jakarta : Prenada Media Group.2011.

Suparman, M. Atwi. Desain Instruksional. Jakarta: Universitas Terbuka, 2004

Desain Instruksional Modern

(Jakarta: Erlangga,2012) 
pengetahuan, dapat membantu mahasiswa dalam perkuliahan, mengenal bentuk modul sebagai sumber belajar yang dapat memotivasi belajar mahasiswa, menjadi acuan bagi dosen lain untuk mengembangkan sumber belajar yang lain. Uji coba selanjutnya adalah uji coba kelompok besar dilakukan terhadap 30 mahasiswa.

Dari hasil penilaian modul pada kelompok besar dapat disimpulkan bahwa modul yang dikembangkan diperoleh rata-rata dari masing-masing aspek sebagai berikut: Aspek Metode rata-rata skor 85,57\% dengan kategori Sangat Baik, Aspek Bahasa diperoleh skor $84,31 \%$ dengan kategori sangat baik, sedang aspek Grafika diperoleh skor 86,73\% dengan kategori Sangat Baik

Dari data diatas dapat dibaca bahwa produk yang dikembangkan $100 \%$ dengan kategori sangat baik. Dengan ini dapat disimpulkan bahwa produk yang dikembangkan layak untuk digunakan dalam kelas. Selain penilaian diatas, mahasiswa uji coba kelompok besar memberikan masukan, saran, komentar untuk perbaikan kualitas produk. Dengan melakukan perbaikan atau revisi produk diharapkan dapat lebih meningkatkan kualitas produk yang sedang dikembangkan. Revisi telah dilakukan sesuai saran saran yang relevan. Adapun kesan dari mahasiswa adalah Belajar dengan modul menyenangkan karena dapat mengatur cara belajar sesuai kemampuan mahasiswa Sudah baik dan menyenangkan.

Setelah produk diujikan pada kelompok besar, kemudian dilakukan langkah penyebaran produk atau penggunaan produk. Dan untuk mengetahui hasil belajar setelah menggunakan modul, maka dilakukan Evaluasi sumatif .

Evaluasi ini dilakukan untuk menentukan hasil belajar mahasiswa setelah menggunakan modul. Hal ini dilakukan dengan cara pre test dan Post Test. Soal untuk pre test diberikan sebelum menggunakan modul dan soal post test diberikan setelah modul digunakan. Pada Pembelajaran Mandiri Berdasarkan evaluasi belajar yang dilakukan pada pre test dan post test maka diperoleh data

T tabel $\alpha 2,04$ dan $\mathrm{t}$ hitung 7,0445, t hitung $>$ $\mathrm{t}$ table yaitu 7,0445 $>2,04$ maka terdapat signifikan antara sebelum menggunakan modul dengan sesudah menggunakan modul dengan pembelajaran mandiri.

Pembelajaran Konvensional Berdasarkan evaluasi belajar yang dilakukan pada pre test dan post test maka diperoleh data:
$\mathrm{T}$ tabel $\alpha 2,04 \mathrm{t}$ hitung $>\mathrm{t}$ table yaitu 3,987 $>$ 2,04 maka terdapat signifikansi antara sebelum menggunakan modul dengan sesudah menggunakan modul dengan pembelajaran konvensional

Dengan kata lain bahwa Penggunaan modul Sejarah Pendidikan Islam terbukti signifikan terhadap peningkatan hasil belajar Sejarah Pendidikan Islam pada mahasiswa Sekolah Tinggi Ilmu Tarbiyah Pemalang. Hal tersebut dibuktikan dengan rata-rata hasil belajar yang lebih tinggi setelah menggunakan modul dibandingkan dengan sebelum menggunakan modul baik dengan model pembelajaran secara mandiri maupun konvensional.

Implikasi hasil penelitian diharapkan dapat meningkatkan mutu bagi Perguruan Tinggi yaitu Sekolah Tinggi Ilmu Tarbiyah Pemalang baik bagi dosen, mahasiswa dan Ketua serta pejabat dilingkungan Sekolah Tinggi Ilmu Tarbiyah Pemalang . Bagi dosen pengampu mata kuliah sejarah pendidikan islam, pengembangan bahan pembelajaran ini yang berupa modul Sejarah Pendidikan Islam dapat meningkatkan efektifitas pembelajaranya, sehingga pembelajaran akan lebih menarik, mendorong semangat belajar mahasiswa, meningkatkan hasil belajar siswa dan meningkatkan profesionalitas dosen serta memunculkan pemikiran bahwa mengajar tidak hanya transfer pengetahuan saja tapi harus memahami karakteristik mahasiswa yang diajar sehinga berdampak pada proses pembelajaran yang menyenangkan dan hasil yang memuaskan sesuai dengan tujuan yang diharapkan. Bagi Mahasiswa, penerapan pengembangan bahan pembelajaran sejarah pendidikan islam membuat pembelajaran lebih menarik karena mahasiswa dapat belajar sesuai dengan kemampuan dan gaya belajar masing-masing mahasiswa sehingga antusias untuk mempelajarinya sehingga akan berpengaruh pada hasil belajar yang meningkat.

Bagi Ketua Sekolah Tinggi Ilmu Tarbiyah Pemalang dan para pejabat dilingkungan, hasil penelitian ini menjadi masukan sebagai salah satu bahan pertimbangan dan kebijakan, terutama yang berkaitan dengan pembelajaran diperguruan Tinggi, dengan melihat hasil dari efektifitas penggunaan modul Sejarah Pendidikan Islam maka menjadi acuan untuk meningkatkan mutu dosen dalam menyampaikan pembelajaran. Hal ini dapat dilakukan dengan diberikan pelatihan tentang penyusunan modul dengan mengundang tutorial agar terbuka 
Tabel 3. Skor Prosentase penilaian Ahli Materi modul Sejarah Pendidikan Islam

\begin{tabular}{|c|l|c|c|}
\hline No. & \multicolumn{1}{|c|}{ Indikator } & $\begin{array}{c}\text { Prosenta } \\
\text { se Skor }\end{array}$ & Kriteria \\
\hline 1. & $\begin{array}{l}\text { Kesesuaian Uraian Materi } \\
\text { Dengan SK dan KD }\end{array}$ & $79,16 \%$ & Sangat Baik \\
\hline 2 & Keakuratan Materi & $91,67 \%$ & Sangat Baik \\
\hline 3 & $\begin{array}{l}\text { Materi Pendukung } \\
\text { Pembelajaran }\end{array}$ & $79,16 \%$ & Sangat Baik \\
\hline 4 & Teknik Penyajian & $95,83 \%$ & Sangat Baik \\
\hline 5 & Penyajian Pembelajaran & $91,66 \%$ & Sangat Baik \\
\hline 6 & $\begin{array}{l}\text { Materi Pendukung } \\
\text { Pembelajaran }\end{array}$ & $89,06 \%$ & Sangat Baik \\
\hline 7 & Jenis Huruf & $91,67 \%$ & Sangat Baik \\
\hline 8 & Letak isi teks & $87,50 \%$ & Sangat Baik \\
\hline 9 & Isi Teks & $91,66 \%$ & Sangat Baik \\
\hline 10 & $\begin{array}{l}\text { Kesesuaian dengan } \\
\text { tingkat perkembangan } \\
\text { mahasiswa }\end{array}$ & $93,75 \%$ & Sangat Baik \\
\hline 11 & Bahasa komunikatif & $93,75 \%$ & Sangat Baik \\
\hline 12 & $\begin{array}{l}\text { Keruntutan dan kesatuan } \\
\text { gagasan }\end{array}$ & $93,75 \%$ & Sangat Baik \\
\hline
\end{tabular}

Dari tabel tersebut dapat dibaca bahwa oleh ahli materi dari 12 indikator dengan butir pertanyaan 35 butir , 100\% penilaian mereka pada kategori sangat baik.Selanjutnya dapat dilanjutkan untuk uji coba produk. Selain penilaian diatas, ahli materi juga memberi masukan, saran dan komentar untuk memperbaiki kualitas produk.

Tabel 4. Saran perbaikan dari ahli materi dan Revisi

\begin{tabular}{|c|l|c|}
\hline No & \multicolumn{1}{|c|}{ Saran } & Revisi \\
\hline 1 & $\begin{array}{l}\text { Kegiatan belajar 4 belum ada } \\
\text { deskripsi kuttab, karena kuttab } \\
\text { masa itu sudah ada dan mata } \\
\text { kuliah sejarah pendidikan islam } \\
\text { salah satu kajian intinya adalah } \\
\text { lembaga pendidikan islam } \\
\text { (Kuttab) }\end{array}$ & Dilaksanakan \\
\hline 2 & $\begin{array}{l}\text { Materi Khulafaur Rosyidin } \\
\text { deskripsinya kurang detail dan } \\
\text { kritis }\end{array}$ & Dilaksanakan \\
\hline 3 & $\begin{array}{l}\text { Referensi kurang representatif } \\
\text { maka perlu diperdalam dengan } \\
\text { referensi yang lebih bagus }\end{array}$ & Dilaksanakan \\
\hline 4 & $\begin{array}{l}\text { Tata tulis diperbaiki seperti kata } \\
\text { islam }\end{array}$ & Dilaksanakan \\
\hline 5 & $\begin{array}{l}\text { Kegiatan belajar 12 ditambahi } \\
\text { materi tentang pendidikan islam } \\
\text { pada masa orde lama, orde baru } \\
\text { dan reformasi }\end{array}$ & Dilaksanakan \\
\hline
\end{tabular}

Penilaian selanjutnya adalah teman sejawat yaitu orang yang secara praktis mengajarkan materi mata kuliah sejarah pendidikan islam,mereka adalah Dosen Sekolah Tinggi Ilmu Tarbiyah Pemalang, beliau adalah Yuliana Habibi M.SI dan Purnama Rozak M.SI. Dari penilaian teman sejawat terhadap 21 indikator dengan 74 butir pertanyaan didapati hasil $100 \%$ mendapat penilaian sangat baik. Selanjutnya dapat dilanjutkan untuk ujicoba produk. Selain memberikan penilaian, teman sejawat memberikan masukan, saran, komentar untuk perbaikan kualitas produk. Hasil Kesimpulannya layak untuk uji coba lapangan dengan revisi sesuai masukan.

Uji coba selanjutnya Uji Coba One to One (Satu lawan satu) pada 3 orang mahasiswa sebagai calon pengguna. Berikut data yang diperoleh pada pelaksanaan uji coba satu lawan satu. Hasil uji coba dari 23 indikator dengan 76 butir pertanyaan adalah $22 \%$ termasuk kategori Baik, $78 \%$ termasuk kategori sangat baik. Sehingga kesimpulannya produk dalam kategori sangat baik. Selanjutnya bisa dilanjutkan pada kelompok kecil setelah memperbaiki dari saran dan masukan dari mahasiswa. Selain penilaian diatas, mahasiswa uji coba satu lawan satu juga memberikan masukan, saran, komentar untuk perbaikan kualitas produk. Revisi telah dilakukan sesuai saran-saran yang relevan. Adapun saran dari responden adalah Tata letak penulis kurang proporsional pada cover modul ,tulisan modul sejarah pendidikan islam pada cover modul kurang jelas, tulisan penerbit pada cover modul terlalu kecil semua saran dari responden dilaksanakan sesuai dengan masukan yang diterima.

Dari saran uji coba one to one pada mahasiswa peneliti melakukan tindak lanjut dari uji coba one to one. Adapun hasil dari tindak lanjut one to one adalah dari 23 indikator dengan 76 butir pertanyaan adalah $100 \%$ termasuk kategori sangat baik, Sehingga kesimpulannya produk dalam kategori sangat baik. Selanjutnya bisa dilanjutkan pada kelompok kecil .Uji Coba Kelompok Kecil

Uji coba kelompok kecil atau small group dilakukan pada responden dengan jumlah 15 Mahasiswa diperoleh hasil terhadap item-item yang dinilai dari 23 indikator dengan 83 butir pertanyaan adalah 91,30\% termasuk kategori sangat baik, dan 8,70\% termasuk kategori baik. Sehingga kesimpulannya produk dalam kategori sangat baik. Selanjutnya bisa dilanjutkan pada kelompok besar. Selain itu, dalam uji coba kelompok kecil mendapatkan saran bahwa Penelitian ini/informasi ini sangat menarik untuk menambah wawasan dan 
mahasiswa benar-benar baru mengenal mata kuliah Sejarah Pendidikan Islam.

Karakteristik Awal Mahasiswa bahwa Mahasiswa semester 2 rata- rata mereka berusia antara 18-25 tahun. Masa ini masuk kedalam masa dewasa dini. (Istilah adult berasal dari kata kerja latin, seperti juga istilah adolescene-adolescere yang berarti "tumbuh menjadi kedewasaan" Orang dewasa adalah individu yang telah menyelesaikan pertumbuhannya dan siap menerima kedudukan dalam masyarakat bersama dengan orang dewasa lainnya. (Elizabeth Harlock, 2006: 246)

Asumsi Mahasiswa yang pernah mengikuti mata kuliah Sejarah Pendidikan islam memiliki mind set atau pola pikir bahwa mata kuliah sejarah pendidikan islam lebih banyak bersifat kognitif atau pengetahuan saja, dan dalam pembelajarannya lebih didominasi oleh dosen, sehingga mahasiswa kurang memiliki ruang gerak dalam proses pembelajarannya.

Langkah keempat yaitu Menulis Tujuan Instruksional Khusus ( TIK). Tujuan Instruksional khusus harus mengandung unsur-unsur yang dapat memberikan petunjuk kepada penyusun tes agar dapat mengembangkan tes yang benar-benar dapat mengukur perilaku yang terdapat didalamnya. Unsur-unsur itu dikenal dengan ABCD yang berasal dari empat kata sebagai berikut: $\mathrm{A}=$ Audience adalah mahasiswa yang akan belajar, yaitu mahasiswa S1 Program Studi Pendidikan Agama Islam semester 2; $\mathrm{B}=$ Behavior adalah perilaku yang spesifik yang akan dimunculkan oleh mahasiswa setelah selesai proses belajarnya dalam pelajaran tersebut; $\mathrm{C}=$ Condition. Komponen ketiga dalam TIK adalah C (Condition). C adalah kondisi yang berarti batasan yang dikenakan kepada mahasiswa atau alat yang digunakan mahasiswa saat ia dites; $\mathrm{D}=$ Degree adalah tingkat keberhasilan mahasiswa dalam mencapai perilaku tersebut.

Langkah kelima yaitu Menulis Tes Acuan Patokan pada tahap ini peneliti melakukan langkahlangkah seperti berikut:

Tahap pertama, menentukan maksud tes, tes yang akan disusun oleh pengembang instruksional akan digunakan untuk dua maksud utama yaitu sebagai berikut: (1) Memberikan umpan balik bagi mahasiswa tentang hasil belajar mahasiswa dalam setiap tahap proses belajarnya; (2) Menilai efektifitas sistem instruksional secara keseluruhan. Untuk ini pengembang instruksional menyusun Tes
Acuan Patokan yang dapat mengukur hasil belajar mahasiswa dalam menguasai seluruh perilaku dalam Tujuan Instruksional Umum dan sampel perilaku dalam Tujuan Instruksional Khusus. Tahap kedua; Membuat tabel spesifikasi untuk setiap tes untuk butir 1a dan 1 b yang terdiri atas empat kolom, yaitu : daftar perilaku, persentase jenis tes, dan jumlah butir tes.

Langkah ke enam : Mengembangkan Strategi Instruksional Strategi Instruksional berkenaan dengan pendekatan pengajaran dalam mengelola kegiatan instruksional untuk menyampaikan materi atau isi pelajaran secara sistematis, sehingga kemampuan yang diharapkan dapat dikuasai oleh mahasiswa secara efektif dan efisien. Langkah ke Tujuh: mengembangkan bahan instruksional . Pada tahap ini peneliti mengembangkan bahan yang dibutuhkan mulai dari mengumpulkan referensi berkaitan dengan materi yang akan dimuat dalam modul; Menelaah referensi yang sudah ada; Membuat kerangka naskah; Mengembangkan kerangka naskah ; Membuat pola naskah yang akan dimuat dalam modul ; Melengkapi ilustrasi ; Mengoreksi kerangka naskah ; Mendesain cover modul depan; punggung dan belakang ; Bekerjasama dengan ahli materi untuk memberikan masukan dan menilai hasil dari naskah yang disusun; Bekerjasama dengan teman sejawat untuk memberikan masukan berkaitan dengan penyajian dan metode yang digunakan dalam modul tersebut; Melakukan revisi terhadap naskah dari hasil penilaian ahli materi dan teman sejawat.

Langkah ke Delapan : Menyusun desain dan melaksanakan evaluasi formatif (Atwi Suparman, 2004:276). Setelah naskah berhasil disusun maka dilakukan uji coba adapun tahapan uji coba sebagai berikut: Telaah pakar yang meliputi Ahli materi dan Teman sejawat.

Ahli Materi terdiri dari 2 orang yang ahli dan kompeten dalam menguasai sejarah pendidikan islam mereka adalah dosen Sekolah Tinggi Agama Islam (STAIN ) Pekalongan yang memiliki disiplin ilmu dalam bidang sejarah pendidikan islam serta memiliki pengalaman mengajar sejarah pendidikan islam.Ahli materi yang menjadi validator adalah Drs.H. Ahmad Zaeni, M.Ag. dan Dwi Istiya, M.Ag. 
karena akan berpengaruh pada tata letak bagian isi dan jumlah halaman buku. Indikator ini mendapatkan penilaian 93,75 \% yang termasuk dalam kategori sangat baik sesuai dengan indikator yang dinilai.

Desain kulit buku meliputi (a) tata letak; (b) Tipografi Kulit Buku; (c) Penggunaan huruf. Tata letak meliputi: Penampilan unsur tata letak pada kulit muka, belakang, dan punggung secara harmonis memiliki irama dan kesatuan serta konsisten; elemen warna, ilustrasi dan tipografi ditampilkan secara harmonis dan saling terkait satu dan lainnya; Ukuran huruf yang lazim untuk buku teks pelajaran adalah 10, 11, dan 12 point. Untuk catatan-catatan tertentu kadang-kadang dipakai huruf dengan ukuran 6 atau 8 point yang terlalu kecil untuk dapat dibaca dengan mudah.

Ukuran huruf 24 point biasanya dipakai untuk judul, ukuran 22 point untuk subjudul.Ukuran huruf yang sama dengan jenis huruf yang berbeda dapat memberikan tampilan yang berbeda. Dalam memilih ukuran huruf yang perlu diperhatikan adalah dapat memuat banyak kata dalam satu baris tanpa melanggar ketentuan jumlah huruf dalam satu baris. Kemudian memperhatikan keseimbangan antara spasi kata dengan spasi baris. Modul yang dirancang dalam penelitian ini isi teks menggunakan huruf book antiqua dengan ukuran font 11. Indikator ini mendapatkan penilaian 84,38 \% yang termasuk dalam kategori sangat baik sesuai dengan indikator yang dinilai.

Tipografi Kulit Buku meliputi: Huruf yang digunakan menarik dan mudah dibaca; Ukuran huruf judul buku lebih dominan dan proporsional dibandingkan (ukuran buku, nama pengarang dan penerbit); Warna judul buku kontras dengan warna latar belakang. Penggunaan huruf meliputi: Huruf yang digunakan mudah dibaca, huruf yang digunakan tidak melelahkan mata, huruf yang digunakan menarik untuk dibaca. Indikator ini mendapatkan penilaian $100 \%$ yang termasuk dalam kategori sangat baik sesuai dengan indikator yang dinilai. Desain isi buku Indikator pemakaian bahasa yang komunikatif diarahkan pada hal-hal seperti pencerminan isi buku yang meliputi: Menggambarkan isi/materi ajar dan mengungkapkan karakter obyek; Bentuk, warna, ukuran, proporsi obyek sesuai realita sehingga tidak menimbulkan salah penafsiran maupun pengertian siswa. Untuk menghasilkan modul, peneliti melakukan langkah-langkah pengembangan dengan
Model Pengembangan Instruksional dengan langkah sebagai berikut:

Langkah Pertama yaitu Identifikasi kebutuhan instruksional dan menulis tujuan instruksional umum ( TIU). Identifikasi kebutuhan instruksional bertujuan untuk mengetahui kebutuhan mahasiswa dalam proses belajar mengajar. Dalam penelitian ini yang akan diteliti adalah dalam proses pembelajaran mata kuliah Sejarah Pendidikan Islam, mata kuliah ini menjadi sorotan karena dianggap mata kuliah yang membosankan, mudah dipelajari tetapi dari segi afektif atau sikap mahasiswa kurang dapat menerapkan. Selanjutnya menulis tujuan instruksional umum (TIU). Dari kegiatan mengidentifikasi kebutuhan instruksional diperoleh jenis pengetahuan, ketrampilan, dan sikap yang tidak pernah dipelajari atau belum dilakukan dengan baik oleh mahasiswa. Jenis pengetahuan, ketrampilan, dan sikap tersebut masih bersifat umum atau garis besar. Ia merupakan hasil belajar yang diharapkan dikuasai mahasiswa setelah menyelesaikan program pendidikan. Hasil belajar ini disebut tujuan instruksional.

Modul sejarah pendidikan islam yang dirancang memiliki tujuan instruksional umum yaitu menerapkan system pendidikan islam dari masa lalu sampai masa sekarang dalam rancang bangun sistem pendidikan islam.

Langkah kedua yaitu melakukan analisis Instruksional yaitu proses menjabarkan perilaku umum menjadi perilaku khusus yang tercantum secara logis dan sistematis. Kegiatan tersebut untuk dimaksudkan untuk mengidentifikasi perilakuperilaku khusus yang menggambarkan perilaku umum secara lebih terperinci. Langkah ketiga yaitu mengidentifikasi perilaku dan karakteristik awal mahasiswa. Mahasiswa yang mengikuti mata kuliah Sejarah Pendidikan Islam disediakan bagi mahasiswa dengan syarat sebagai berikut: Terdaftar sebagai mahasiswa Sekolah Tinggi Ilmu Tarbiyah( STIT ) Pemalang pada semester ini di jurusan S1 Pendidikan Agama Islam semester II, Mata kuliah ini sebagai mata kuliah prasyarat untuk mengikuti mata kuliah Ilmu Pendidikan islam, mahasiswa sudah lulus mata kuliah umum ( MKU) dengan nilai minimal $\mathrm{B}+$. Mahasiswa yang akan mengikuti mata kuliah ini belum pernah mengikuti mata kuliah sejarah pendidikan islam, karena mata kuliah ini merupakan mata kuliah khusus setelah mereka sudah lulus mengikuti mata kuliah umum (MKU). Sehingga 
mahasiswa menghasilkan 62,5 \% membutuhkan modul dan 37,5 \% tidak membutuhkan modul. Lalu peneliti melakukan analisis bahwa modul yang cocok untuk mahasiswa Sekolah Tinggi Ilmu Tarbiyah Pemalang adalah sebuah modul dengan metode pembelajaran secara mandiri dan konvensional karena perkuliahan yang dilakukan selama ini bersifat monoton dan pembelajaran diperlukan sebuah sumber belajar berupa modul yang dapat membantu pemahaman mahasiswa terhadap mata kuliah Sejarah Pendidikan Islam.

Sebelum merancang modul peneliti melakukan analisis kurikulum yaitu bahwa mata kuliah Sejarah Pendidikan Islam adalah mata kuliah prasyarat sebelum mengikuti mata kuliah Ilmu Pendidikan Islam dan harus lulus mata kuliah umum dengan berat 2 sks, mata kuliah Sejarah Pendidikan Islam diberikan pada mahasiswa semester 2 atau genap. Perkuliahan Sejarah Pendidikan Islam ditempuh dengan 12 materi atau pokok bahasan.

Desain dan rancangan modul Sejarah Pendidikan Islam yang dikembangkan sudah sesuai dengan kebutuhan dan karakteristik mahasiswa Sekolah Tinggi Ilmu Tarbiyah Pemalang, yaitu dilihat dari isi, Penyajian, Bahasa dan Grafika. Dari segi isi Modul yang dikembangkan sudah sesuai yaitu: (1) kesesuaian uraian materi dengan standar kompetensi atau SK dari kompetensi dasar atau KD yang terdapat dalam kurikulum mata kuliah yang bersangkutan; (2)Keakuratan materi; dan (3) materi pendukung pembelajaran (Masnur Muslich, 2010 :292). Dari indikator tersebut didapati hasil penilaiannya bahwa modul yang dikembangkan dari segi isi dalam kategori sangat baik dengan prosentase skor rata-rata $84,72 \%$.

Dari segi penyajian ada tiga indikator dalam penilaian kelayakan penyajian: (1)Teknik penyajian; (2)Penyajian Pembelajaran; dan (3)Kelengkapan Penyajian. Teknik penyajian meliputi: Sistematika penyajian, keruntutan penyajian, keseimbangan antar bab, indikator ini mendapatkan penilaian 95,83\% yang termasuk dalam kategori sangat baik sesuai dengan indikator yang dinilai. Penyajian pembelajaran meliputi: berpusat pada siswa, mengembangkan ketrampilan proses, memperhatikan aspek keselamatan kerja, indikator ini mendapatkan penilaian 91,66\% yang termasuk dalam kategori sangat baik sesuai dengan indikator yang dinilai. Kelengkapan penyajian meliputi : (a) Bagian pendahuluan memuat prakata, petunjuk penggunaan dan daftar isi;(b)Bagian isi memuat Gambar, ilustrasi, tabel, rujukan/sumber acuan, soal latihan atau rangkuman setiap bab.(c) Bagian penutup/ penyudah memuat daftar pustaka, daftar istilah (Glosarium) atau petunjuk pengerjaan jawaban soal latihan terpilih.Indikator ini mendapatkan penilaian $89,06 \%$ yang termasuk dalam kategori sangat baik sesuai dengan indikator yang dinilai.

Dari segi bahasa dalam penilaian uji kelayakan bahasa ada tiga indikator yang dinilai; (1) Kesesuaian pemakaian bahasa dengan tingkat perkembangan siswa indikator ini mendapatkan penilaian 93,75\% yang termasuk dalam kategori sangat baik sesuai dengan indikator yang dinilai. (2) Pemakaiaan bahasa yang komunikatif indikatornya meliputi : (a) Keterbacaan pesan ;(b) Ketepatan kaidah bahasa indikator ini mendapatkan penilaian 93,75 \% yang termasuk dalam kategori sangat baik sesuai dengan indikator yang dinilai.; (3) Pemakaian bahasa memenuhi syarat keruntutan dan keterpaduan alur berpikir meliputi (a) keruntutan dan keterpaduan antar bab; (b) keruntutan dan keterpaduan antar paragraf.Indikator ini mendapatkan penilaian 93,75 $\%$ yang termasuk dalam kategori sangat baik sesuai dengan indikator yang dinilai. Dilihat segi kegrafikan ada 3 indikator yang dinilai yaitu (1) Ukuran buku; (2) Desain kulit buku; dan (3) Desain isi buku.

Menentukan ukuran buku harus memperhatikan faktor kepraktisan penggunaannya dan juga faktor lain yang harus diperhatikan seperti jenis informasi yang disampaikan, sasaran pembaca, kesukaan pembaca, biaya produksi dan pemasaran, ukuran kertas yang standar dan efisiensi penggunaan bahan produksi,seperti kertas dan tinta cetak. (BP.Sitepu, 2012:128). Agar kertas tidak banyak terbuang, ukuran buku mengacu pada standar ukuran kertas yang ditetapkan oleh International Organization for Standardization (ISO). Ukuran buku dibedakan antara yang berbentuk vertikal/potret/tegak, horizontal/landscape/baring, dan oblong/simetris. Ukuran buku bergantung pada jenis/isi buku serta sasaran pembaca.

Ukuran modul yang dirancang dalam penelitian ini yaitu sesuai standar ISO berukuran B5 (176 x 250) (mm) dengan toleransi perbedaan ukuran antara 0-20 mm dengan ketebalan 157 halaman dengan bentuk Vertikal/potret/tegak (BP. Sitepu, 2006:102) dan ukuran buku sesuai dengan materi isi buku 
proses pembelajaran yang dapat diterapkan oleh para dosen dan meningkatkan efektifitas pembelajaran sejarah pendidikan islam.

\section{METODE PENELITIAN}

Penelitian ini berupa penelitian pengembangan atau (development research) yaitu suatu proses atau langkah-langkah untuk mengembangkan suatu produk baru atau menyempurnakan produk yang telah ada, yang dapat dipertanggungjawabkan. Penelitian ini menghasilkan modul pembelajaran untuk mempelajari mata kuliah sejarah pendidikan islam. Modul ini ditujukan agar memberikan kesempatan kepada mahasiswa untuk dapat mempelajari modul ini secara mandiri dan konvensional.

Untuk menghasilkan modul pembelajaran peneliti melakukan prosedur pengembangan dengan menggunakan Model Pengembangan Instruksional(MPI) yaitu: (1)Mengidentifikasi kebutuhan instruksional dan menulis tujuan instruksional umum; (2)Melakukan analisis instruksional; (3)Mengidentifikasi perilaku dan karakteristik awal peserta didik; (4)Menulis Tujuan Instruksional Khusus ( TIK); (5)Menulis Tes Acuan Patokan; (6)Mengembangkan Strategi Instruksional; (7)Mengembangkan Bahan Instruksional; Menyusun desain dan melaksanakan evaluasi formatif yang termasuk dalamnya kegiatan merevisi. (M.Atwi Suparman, 2012:116). Instrumen pengumpulan data adalah bahan ajar berupa modul Sejarah Pendidikan Islam, kuesioner/angket dan tes pengukuran tingkat kognitif hasil produk.

\section{Validasi, Evaluasi dan Revisi}

Setelah modul selesai dibuat dan sebelum diuji-cobakan ke kelas, maka dilakukan evaluasi terlebih dahulu dengan melibatkan evaluasi ahli yang kompeten di bidang Sejarah Pendidikan Islam. Para ahli tersebut adalah yang kompeten di bidangnya yaitu, ahli materi sejarah pendidikan islam, dan teman sejawat.

Ahli materi adalah orang yang berkompeten dalam menguasai konsep materi Sejarah Pendidikan Islam terdiri dari 2 orang yang memiliki disiplin ilmu dalam bidang Sejarah Pendidikan Islam. Pada tahapan ini ahli pakar materi memberikan penilaian dengan menggunakan instrument yang telah dibuat. Teman Sejawat adalah orang yang berkompeten menguasai secara praktis teori dalam proses belajar mengajar.
Evaluasi selanjutnya evaluasi satu-satu(one to one), evaluasi kelompok kecil dan uji coba lapangan pada kelompok besar.

Skala penilaian yang digunakan pada masing-masing instrumen untuk menguji bahan ajar pembelajaran terdiri dari empat kategori yang telah diatur oleh peneliti berdasarkan pada kriteria interpretasi skor untuk skala Likert yaitu : Skor 4=Sangat Setuju; Skor 3=Setuju; Skor 2= Kurang Setuju; Skor 1=Tidak Setuju, Batas baik dan tidaknya kualitas modul pembelajaran sejarah pendidikan islam dapat dijadikan sebagai alternatif sumber pendukung pembelajaran. Adapun kriteria interpretasi skornya adalah $0 \%-25 \%=$ Sangat kurang baik; $26 \%-50 \%=$ Kurang baik; $51 \%-75 \%=$ Baik; $76 \%-100 \%=$ Sangat Baik.

Sebelum instrumen test hasil belajar Sejarah Pendidikan Islam digunakan sebagai alat pengumpul data pada evaluasi sumatif, maka terlebih dahulu diketahui validitas dan Reliabilitas untuk mengetahui sejauhmana ketepatan dan kecermatan suatu alat ukur. Uji validitas instrumen tes hasil belajar dilakukan dengan menggunakan rumus korelasi point biserial. Untuk menguji reliabilitas menggunakan KR-20. Untuk menilai kwalitas produk modul yang dengan menggunakan angket, angket tersebut berbentuk pilihan yang harus di check list (v) dengan empat pilihan jawaban. Untuk validitas instrumen penilaian modul dalam bentuk skala likert maka digunakan rumus korelasi product moment dan untuk menghitung reliabilitas digunakan rumus Alpha Cronbach. Selanjutnya dilakukan Uji t -tes untuk uji signifikansi antara pre test dan Post test untuk mengetahui taraf signifikansi terhadap hasil belajar antara sebelum menggunakan modul dan sesudah menggunakan modul.

\section{HASIL PENELITIAN DAN PEMBAHASAN}

Penelitian ini menghasilkan modul Sejarah Pendidikan Islam dengan harapan modul ini membantu mahasiswa dalam mempelajari mata kuliah Sejarah Pendidikan Islam. Sebelum menghasilkan modul, peneliti melakukan penelitian pendahuluan untuk mengetahui tingkat kebutuhan mahasiswa dan kesulitan yang dialami mahasiswa ketika mempelajari mata kuliah Sejarah Pendidikan Islam dilakukan dengan menyebarkan angket atau kuesioner. Quesioner disebarkan kepada 32 mahasiswa hasil kuesioner pada penelitian pendahuluan pada 32 
dan teknologi; (4) Akrab dengan pemakainya yaitu media yang digunakan mudah dioperasikan, intruksikan yang disampaikan mudah dimengerti dan mudah ditanggapi oleh pembelajar, bahasa yang digunakan adalah besifat umum, sederhana dan mudah dimengerti oleh pembelajar. Media, penyajian bahan pelajaran dan bahasa yang dipergunakan membuat pembelajar merasa akrab dengan modul serta termotivasi untuk mempelajarinya.

Modul sebagai bahan pembelajaran untuk keperluan bahan ajar secara konvensional memiliki ciri-ciri ; (1) Berisi pesan.Pesan yang dimaksud ialah bahan pembelajaran yang harus dipelajari oleh peserta didik;(2) Sistematis, Urutan konsep atau materi ditata berdasarkan struktur pengetahuan atau ketrampilan tertentu dengan urutan yang memudahkan pembelajar memperoleh kompetensi yang diharapkan;(3) Menggunakan prinsip-prinsip didaktik metodik, Dalam penyusunan modul dikemas bedasarkan teori belajar dan pembelajaran yang sesuai dengan sifat pengetahuan atau ketrampilan tertentu, sesuai karakteristik pembelajar; (4) Relevansi, Disusun sesuai untuk mencapai tujuan pembelajaran;(5) Bersifat khusus, artinya dirancang khusus untuk tujuan tertentu untuk pembelajar dengan ciri tertentu serta dalam lingkungan dan waktu belajar dan pembelajaran tertentu pula. (Sitepu, 2006:1) Dari ciri tersebut dapat disimpulkan bahwa dalam penelitian ini akan disusun modul atau bahan pembelajaran secara mandiri dan secara konvensional dalam mempelajari mata kuliah sejarah pendidikan islam di Sekolah Tinggi Ilmu Tarbiyah.

Sistematika modul terdiri dari tiga bagian utama yaitu Bagian awal modul berisi pendahuluan, bagian inti berisi bahan pelajaran, dan bagian akhir modul berisi tes sumatif;(1) Bagian awal memberikan informasi umum tentang bahan pelajaran, kegunaan, tujuan pembelajaran umum, susunan dan keterkaitan antar judul modul, bahan pendukung lainnya dan petunjuk untuk mempelajari modul;(2) Bagian inti terdiri atas unit-unit pelajaran. Masing-masing unit terdiri atas pendahuluan, kegiatan belajar, dan daftar pustaka. Pendahuluan berisi cakupan materi (Deskripsi singkat), tujuan pembelajaran khusus, perilaku/kemampuan awal, manfaat dan urutan pokok bahasan secara logis dan petunjuk belajar/ cara mempelajari modul, Kegiatan belajar mencakup uraian bahan ajar contoh-contoh, latihan, rangkuman, tes formatif dan kunci jawaban, Daftar Pustaka berisi daftar sumber dan bacaan yang dapat dipergunakan pembelajar untuk memperkaya isi pokok bahasan. Bagian akhir berisi penutup modul,glosarium, dan lampiran-lampiran yang terkait dengan modul

Modul sebagai salah satu bahan atau media cetak dalam proses belajar mengajar memiliki kelebihan dan keterbatasan modul. Modul memiliki kelebihan sebagai berikut: (1)Menentukan kecepatan sendiri. Para siswa bisa menyelesaikan materi berdasarkan kecepatan mereka sendiri; (2) Tervalidasi. Modulmodul diuji dan divalidasi sebelum disebarkan. (Smaldino,2011:280);(3) Bentuk fisiknya mudah dibawa-bawa, memudahkan pengguna untuk membacanya sewaktu-waktu kapan saja dan dimana saja.; (4) Ekonomis, mudah pendistribusiannya, serta mudah untuk dipindah-pindah; (5)Pembaca diberi kesempatan untuk mencerna isi informasi yang terkandung didalamnya; (6)Memungkinkan pembaca mengulang-ulang bacaannya oleh karena itu pembaca bisa mengulang hal-hal penting yang sebelumnya terlewati; (7) Mampu menghasilkan kesamaan pengertian terhadap informasi yang terkandung didalamnya (Benny A. Pribadi \& Yuni Katrin, 2009:8). Keterbatasan Modul : (1) Kualitas modul,kualitas modul bervariasi; beberapa diantaranya merupakan modul latihan dan praktik yang tidak menginspirasi dan berkualitas rendah; (2) Tidak dapat menampilkan gerak dan suara, penulis sudah berusaha menggambarkan dalam tulisan; (3) Modul dengan bahan cetak terbuat dari kertas, apabila kualitasnya jelek maka cepat rusak dan tidak tahan air.

Merujuk pada analisis tersebut rumusan masalah dalam penelitian ini adalah modul seperti apakah yang sesuai untuk mempelajari mata kuliah sejarah pendidikan islam untuk meningkatkan mutu hasil belajar mahasiswa Sekolah Tinggi Ilmu Tarbiyah Pemalang?

Berdasarkan latar belakang diatas, maka Tujuan penelitian pengembangan ini adalah untuk mengembangkan modul yang sesuai untuk mempelajari mata kuliah sejarah pendidikan islam dalam meningkatkan mutu hasil belajar mata kuliah sejarah pendidikan islam. Secara teoritis, temuan dalam penelitian ini diharapkan dapat memberikan masukan dalam pengembangan bahan pembelajaran, agar proses pembelajaran dapat tercapai sesuai dengan tujuan yang diinginkan. Secara praktis, hasil penelitian ini diharapkan dapat menjadi acuan dalam 
dirumuskan secara khusus dan jelas. (S. Nasution, 2008:205)

Dalam buku lain menyebutkan modul dapat diartikan sebagai satuan program pembelajaran terkecil yang dapat dipelajari oleh peserta didik secara perseorangan (self instuction) (Andi Prastowo, 2011:105); Modul dapat juga diartikan sebagai bahan belajar yang dirancang secara sistematis berdasarkan kurikulum tertentu dan dikemas dalam bentuk satuan pembelajaran terkecil dan memungkinkan dipelajari secara mandiri dalam satuan waktu tertentu (Purwanto, dkk., 2007: 9). Modul adalah sebuah buku yang ditulis dengan tujuan agar peserta didik dapat belajar secara mandiri tanpa atau dengan bimbingan guru.(Abdul Majid, 2011:176). Dari beberapa pengertian modul diatas dapat disimpulkan bahwa modul dapat digunakan secara mandiri dan juga dengan bimbingan dosen atau konvensional.

Bahan pembelajaran ini menjadi sangat penting karena merupakan satu kesatuan program yang dapat mengukur tujuan. Tujuan utama sistem modul adalah untuk meningkatkan efisiensi dan efektifitas pembelajaran di sekolah, baik waktu, dana, fasilitas, maupun tenaga guna mencapai tujuan secara optimal. Selain itu sebagaimana dirumuskan oleh Purwanto dkk Tujuan disusunnya modul ialah agar peserta didik dapat menguasai kompetensi yang diajarkan dalam diklat atau kegiatan pembelajaran dengan sebaik-baiknya. (Purwanto dkk, 2007:10)

Modul juga dapat disusun untuk keperluan belajar mandiri, yaitu suatu sistem yang dapat dipandang sebagai struktur, proses maupun produk. Sebagai suatu struktur maksudnya adalah suatu susunan dengan hierarki tertentu.(Yusuf Hadi Miarso, 2011:251)

Modul memiliki beberapa fungsi diantaranya: (1) Bahan ajar mandiri. Penggunaan modul dalam proses pembelajaran berfungsi meningkatkan kemampuan peserta didik untuk belajar sendiri tanpa tergantung kepada kehadiran pendidik; (2) Pengganti fungsi pendidik. Modul sebagai bahan ajar yang harus mampu menjelaskan materi pembelajaran dengan baik dan mudah dipahami oleh peserta didik sesuai tingkat pengetahuan dan usia mereka; (3) Sebagai alat evaluasi. Modul menuntut peserta didik untuk dapat mengukur dan menilai sendiri tingkat penguasaannya terhadap materi yang telah dipelajari; (4) Sebagai bahan rujukan bagi peserta didik. Modul mengandung berbagai materi yang harus dipelajari oleh peserta didik. (Andi Prastowo,2011: 107-108) . Modul dapat dibedakan berdasarkan jenisnya yang dapat dilihat dari penggunaanya dan penyusunannya. Pertama menurut penggunaanya, modul terbagi menjadi dua macam yaitu modul untuk peserta didik dan modul untuk pendidik. Modul untuk peserta didik berisi kegiatan belajar yang dilakukan oleh peserta didik, sedangkan modul untuk pendidik berisi petunjuk pendidik, tes akhir modul dan kunci jawaban tes akhir modul.

Kedua Menurut Tujuan penyusunannya, Modul dapat dibedakan menjadi dua jenis yaitu modul inti (modul dasar) dan modul pengayaan. Modul inti adalah modul yang disusun dari kurikulum dasar, yang merupakan tuntutan dari pendidikan dasar umum yang diperlukan oleh seluruh warga indonesia. Modul pengajaran ini merupakan hasil penyusunan dari unit-unit program yang disusun menurut tingkat (kelas) dan bidang studi (mata pelajaran). Sedangkan modul pengayaan disusun sebagai bagian dari usaha untuk mengakomodasi peserta didik yang telah menyelesaikan dengan baik program pendidikan dasarnya mendahului teman-temannya. Dalam penelitian ini secara khusus modul yang akan dikembangkan adalah modul yang digunakan untuk peserta didik atau mahasiswa di Sekolah Tinggi Ilmu Tarbiyah Pemalang semester 2 dalam mempelajari mata kuliah Sejarah Pendidikan Islam.

Modul sebagai bahan pelajaran mandiri memiliki ciri-ciri sebagai berikut: 1) belajar mandiri, bahan pelajaran disusun sedemikian rupa sehingga pembelajar dapat memahaminya tanpa atau sedikit mungkin bantuan orang lain. (Sitepu, 2006:109) Agar pembelajar dapat belajar mandiri dengan menggunakan modul, maka disamping selengkap dan sejelas mungkin,modul disertai bahan evaluasi yang memungkinkan pembelajar dapat mengukur sendiri hasil belajarnya; 2) tuh yaitu Bahan masing-masing unit pelajaran disusun secara utuh untuk mencapai suatu kompetensi dasar atau indikator kompetensi. Dengan demikian pemelajar mempelajari bahan pelajaran dari suatu modul secara lengkap dan tuntas;(3) Berdiri sendiri artinya disamping memuat bahan pelajaran yang lengkap untuk setiap unit, modul merupakan paket belajar yang berdiri sendiri dan tidak tergantung pada media lain;(3) Dapat disesuaikan isi (perangkat lunak) dan media (perangkat keras) yang dapat digunakan dapat segera disesuaikan dengan perkembangan ilmu pengetahuan 


\title{
Pengembangan Modul Mata Kuliah Sejarah Pendidikan Islam Di Sekolah Tinggi Ilmu Tarbiyah Pemalang
}

\begin{abstract}
Nisrokhah*
Abstract: This research is the development of research is a study to produce a product in the form of modules History of Islamic Education. The purpose of this research is to develop a module that is suitable for studying the subjects history of Islamic education in improving the quality of learning outcomes. The module is designed to be able to learn independently and conventional. In developing this module uses Instructional Development Model in starting to identify instructional needs in preparing the design and carry out formative evaluation and summative evaluation to determine learning outcomes in using the module . Results of this study found that the modules developed fit the needs of students of the School of Pemalang
\end{abstract}

Keywords: conventional,self of contained, modules, development.

Abstrak: Penelitian ini berupa penelitian pengembangan yaitu suatu penelitian untuk menghasilkan suatu produk dalam bentuk modul Sejarah Pendidikan Islam. Tujuan penelitian ini adalah mengembangkan modul yang sesuai untuk mempelajari mata kuliah sejarah pendidikan islam dalam meningkatkan mutu hasil belajar. Modul dirancang untuk dapat mempelajarinya secara mandiri dan konvensional. Dalam mengembangkan modul ini menggunakan Model Pengembangan Instruksional di mulai dari Mengidentifikasi kebutuhan instruksional sampai pada menyusun desain dan melaksanakan evaluasi formatif serta dilakukan evaluasi sumatif untuk mengetahui hasil belajar dalam menggunakan modul . Dari penelitian ini didapati hasil bahwa modul yang dikembangkan cocok atau sesuai dengan kebutuhan mahasiswa Sekolah Tinggi Ilmu Tarbiyah Pemalang.

Kata kunci: Konvensional, Mandiri, Modul, Pengembangan.

\section{PENDAHULUAN}

Mata kuliah sejarah pendidikan islam merupakan mata kuliah yang membahas secara komprehensif mengenai perkembangan pendidikan islam dari masa lalu hingga masa sekarang serta dampak aplikasinya dalam pendidikan dan pembelajaran. Agar proses pembelajaran tersebut menarik dan menyenangkan diperlukan strategi dalam penyampaian mata kuliah karena mata kuliah ini dianggap mata kuliah yang monoton yang hanya terbatas pada penyampaian materi yang hanya berisi cerita tentang sejarah pendidikan islam. Sehingga berdampak pada hasil belajar, sebagian dari mereka rata-rata nilai pada mata kuliah sejarah pendidikan islam hasilnya minimal $\mathrm{B}+$ dan sebagian besar mereka mendapat A, karena ketika ujian mereka lebih ditekankan pada aspek kognitif saja atau lebih banyak hafalan yang sifatnya teoritis. Dari hasil studi pendahuluan yang dilakukan peneliti ditemukan salah satu faktor yang mempengaruhi hasil belajar tersebut adalah faktor minimnya fasilitas pendukung seperti terbatasnya bahan pembelajaran salah satunya adalah modul. terhadap 32 mahasiswa didapati hasil 62, $5 \%$ membutuhkan modul dan 37,5 $\%$ tidak membutuhkan modul. Modul merupakan unit yang lengkap yang berdiri sendiri dan terdiri atas suatu rangkaian kegiatan belajar yang disusun untuk membantu siswa mencapai sejumlah tujuan yang

* Nisrokhah Dosen di Sekolah Tinggi Ilmu Tarbiyah Pemalang, Klegen Comal, Pemalang 52363, Telepon: 085742807459Email: nisrokhaabduh@yahoo.co.id 
orang lain, tetapi juga mampu menilai orang lain, sehingga dituntut menjadi sosok yang objektif. Tidak melihat kepada "siapa" yang memberikan jawaban, tetapi jawaban "apa" yang mampu diberikan.

Kedua, langkah-langkah Dick \& Carey yang digunakan dalam pengembangan bahan ajar berbasis Pepro Kreasi ini telah memberikan sumbangan pemikiran terhadap pengembangan desain model pembelajaran dan proses pengembangan bahan ajar yang digunakan dalam kegiatan pembelajaran di kelas. Untuk merancang dan mengembangkan sebuah buku sumber belajar berbasis Pepro Kreasi sangat diperlukan bagi peningkatan kemampuan siswa dan guru dalam melaksanakan kegiatan belajar mengajar. Sehingga bahan ajar yang sudah melalui berbagai proses uji dan revisi, dapat mempermudah dan menjadi acuan dalam melaksanakan pembelajaran.

Ketiga, implikasi positif terhadap dampak uji coba buku pengayaan berbasis Pepro Kreasi ini tidak hanya terlihat dari minat dan motivasi, tetapi juga tergambar dari peningkatan hasil belajar siswa yang sudah dilakukan subjek uji coba. Jika sebelum menggunakan buku pengayaan berbasis Pepro Kreasi guru hanya terbatas pada RPP dan metode pembelajaran yang bersifat monoton, maka setelah penggunaan buku pengayaan guru bisa memberikan pembelajaran kepada siswa dengan menggunakan metode aktif dan kreatif sehingga tidak menjadi pembelajaran yang membosankan. Metode pembelajaran dikelas tidak terpaku pada ceramah, namun diterapkan model diskusi agar proses pembelajaran menjadi lebih interaktif, kelas diskusi juga terlihat lebih variatif. Implikasi bagi siswa secara keseluruhan yaitu pembelajaran menjadi lebih menarik, munculnya berbagai kreativitas dan perubahan perilaku siswa khususnya dalam pembelajaran matematika menjadi lebih baik.

\section{DAFTAR RUJUKAN}

Chambers, P. Teaching Mathematics: Developing as a Reflective Secondary Teacher. (Thousand Oaks : Corwin Press : 2008).h.88

Gultom, Syawal. "Hasil Uji Kompetensi Guru Masih di Bawah Harapan", www.tempo.co/ read/news/2012/08/03/079421057/Hasil-UjiKompetensi-Guru-Masih-di-Bawah-Harapan (diakses, 3 Juli 2014)
Gall, Damien M., dan Walter R. Borg. Educational Research: An Introduction. New York: Longman, Inc.

Joyce, B. And Weil, M. Models of Teaching. (New Jersey: Prantice Hall, 2002).

Kementerian Pendidikan Nasional, Laporan Hasil Studi BERMUTU 2010 Dampak DBL KKG/ MGMP (Jakarta, Badan Penelitian dan Pengembangan Pusat Penilaian Pendidikan, 2010).

Kunandar, Dr. Penilaian Autentik. Suatu Pendekatan Praktis (Jakarta: Raja Grafindo Persada, 2013)

Miarso, Yusufhadi. Menyemai Benih Teknologi Pendidikan. Jakarta: Kencana 2008.

Peraturan Pemerintah Nomor 19 Tahun 2005 Tentang Standar Nasional Pendidikan, Pasal 28, Ayat 3.

Suparman,Atwi. Desain Instruksional. Jakarta: Universitas Terbuka, 2010.

Yager, R.E. Science/Technology/Society as reform in science education. (New York: State University of New York,2 
kalangan terbatas.

Pencapaian kompetensi peserta didik tidak hanya dibandingkan dengan kompetensi peserta didik lainnya, tetapi dibandingkan juga dengan standar kriteria ketuntasan minimal (KKM), yang ditetapkan berdasarkan; (1) tingkat kompleksitas materi, (2) kemampuan sumber daya pendukung dalam penyelenggaraan pembelajaran, dan (3) tingkat kemampuan (intake) rata-rata peserta didik di sekolah yang bersangkutan.

Penelitian ini memiliki keterbatasan, yaitu: Dalam pelaksanaannya, mulai dari proses penelitian pendahuluan, pengembangan produk, dan evaluasi formatif disadari sepenuhnya masih dtemukan keterbatasan-keterbatasan yang menjadi catatan, baik oleh peneliti maupun peneliti berikutnya. Hal pertama yang menjadi catatan sebagai keterbatasan hasil pengembangan ini adalah, bahwa bahan ajar yang dihasilkan masih bersifat sebagai pelengkap yang di desain untuk meningkatkan minat belajar siswa dan menambah wawasan keilmuwan. Jadi guru harus tetap membutuhkan bahan ajar lain.

Dalam kegiatan pembelajaran menggunakan penilaian Pepro Kreasi, maka dituntut profesionalisme guru dalam melakukan pengamatan dan penilaian agar diperoleh berbagai data yang dapat memberikan gambaran perkembangan belajar siswa.

Ditinjau dari sisi dukungan teori model yang digunakan, bahwa model pengembangan ini menggunakan model Dick \& Carey. Dari sepuluh langkah pengembangan yang ada, penelitian pengembangan ini hanya sampai pada langkah kedelapan, yakni evaluasi formatif.

Pengembangan model pembelajaran harus disesuaikan dengan perkembangan kurikulum yang digunakan, sedangkan kurikulum yang digunakan selalu berubah sesuai dengan perkembangan zaman. Sehingga diperlukan model pembelajaran terbaru dan upgrading secara terus-menerus untuk menyelaraskan dengan perkembangan tersebut.

\section{KESIMPULAN}

Kesimpulan dalam penelitian ini adalah: pertama, strategi penggunaan pendekatan realistik yang berdampak langsung pada domain Pepro Kreasi adalah dengan memberikan contoh soal konkrit yang dekat dengan kehidupan sehari-hari siswa. Kedua, tahapan untuk merancang dan implementasi perangkat pembelajaran matematika agar dapat digunakan dalam model pembelajaran matematika berbasis Pepro Kreasi adalah dengan melakukan evaluasi formatif secara bertahap. Ketiga, Desain model pembelajaran matematika berbasis Pepro Kreasi terbukti dapat meningkatkan penguasaan kompetensi siswa, yang bukan hanya kompetensi kognitif (yang di dalamnya terdapat ranah pengetahuan dan sikap) saja, tapi lebih jauh meningkatkan kompetensi afektif (di dalamnya terdapat ranah aplikasi) dan psikomotorik (di dalamnya terdapat ranah keterampilan). Sehingga dapat disimpulkan bahwa pengembangan model pembelajaran matematika berbasis Pepro Kreasi dapat meningkatkan kompetensi, minat dan hasil belajar matematika siswa.

Pengembangan model pembelajaran matematika berupa bahan ajar berbasis Pepro Kreasi memberikan dampak dalam peningkatan kompetensi siswa dan kemampuan guru yang sebelumnya tidak berkembang secara optimal. Selain itu hasil temuan juga berdampak pada guru agar mempersiapkan kurikulum 2013 dengan mempersiapkan sumber belajar yang relevan dengan kebutuhan di lapangan, perlu kerjasama antar antar pihak dalam mendesain dan melaksanakan pembelajaran bagi peningkatan kompetensi siswa. Implikasi positif juga diberikan bagi guru dalam menerapkan kurikulum 2013 yang berbasis penilaian autentik. Oleh sebab itu, penting untuk dijadikan perhatian oleh pemerintah daerah tentang adanya kebijakan bahwa buku sumber belajar yang telah dikembangkan ini dapat dipergunakan di sekolah.

Pertama, pendekatan realistik yang digunakan dalam model pembelajaran Pepro Kreasi terbukti memudahkan dan membantu siswa memahami materi yang diberikan, karena materi diberikan dengan didekatkan pada kehidupan sehari-hari siswa. Hal ini disebabkan bahwa sebenarnya siswa sudah memiliki pengetahuan dan pengalaman yang berbeda satu dengan lainnya, selain itu jenjang pendidikan yang mengharuskan model dan pendekatan pembelajaran yang sesuai dengan tingkat kemampuan dan perkembangan peserta didik. Sehingga dengan pendekatan ini pelaksanaan proses pembelajaran menjadi lebih menarik karena di desain dengan kegiatan pembelajaran yang menuntut siswa aktif dan kreatif. Belajar menjadi manusia yang tidak hanya bisa dinilai 
model pembelajaran berbasis Pepro Kreasi ini merupakan penelitian yang dilaksanakan dengan menitikberatkan pada penilaian autentik, yaitu kegiatan menilai peserta didik yang menekankan pada apa yang seharusnya dinilai, baik proses maupun hasil dengan berbagai instrumen penilaian yang disesuaikan dengan tuntutan kompetensi yang ada di Standar Kompetensi (SK) dan Kompetensi Dasar (KD). Penilain yang dilakukan dalam model ini adalah penilaian untuk mendapatkan nilai pengetahuan, proses, kreativitas, aplikasi, dan sikap peserta didik. Baik sikap dalam kehidupan sehari-hari maupun sikap terhadap pembelajaran matematika. Pelaksanaan penilaian tidak hanya dilimpahkan pada guru, tetapi dengan melibatkan peserta didik. Peserta didik diberikan penjelasan tentang aspek-aspek penilaian yang sudah dipaparkan guru dalam lembar penilaian. Hasil penilaian siswa selanjutnya diverifikasi oleh guru, karena siswa belum bisa sepenuhnya menilai temannya secara objektif. Pelaksanaan penilaian tersebut disesuaikan dengan perkembangan karakteristik peserta didik sesuai dengan jenjangnya.

Penelitian yang dilakukan menghasilkan temuan dalam hal kemampuan guru dalam melaksanakan evaluasi pembelajaran matematika di madrasah Tsanawiyah Al-Ishlahuddiny. Model pembelajaran ini dapat diterapkan sesuai dengan kurikulum nasional 2013, karena terdapat domain penilaian yang tidak jauh beda dengan standar penilaian yang ada pada kurikulum 2013.

Berdasarkan temuan penelitian maka pembahasan hasil penelitian ini akan dijabarkan di bawah ini:

Desain pengembangan model dalam pembelajaran matematika berbasis Pepro Kreasi mengacu pada dua desain, yaitu desain model pembelajaran, yang didalamnya berisi desain penilain Pepro Kreasi dan desain buku pengayaan. Desain penilaian dalam model pembelajaran Pepro Kreasi diantaranya; (1) penilaian domain pengetahuan dan aplikasi, diperoleh dari nilai ulangan harian, ulangan tengah semester (UTS) dan ulangan akhir semester (UAS), (2) penilaian domain sikap, diperoleh dari nilai diskusi dan presentasi dengan format penilaian teman sejawat, (3) penilaian domain proses, diperoleh dari proses penyelesaian masalah matematika yang berupa tahap persiapan, tahap pelaksanaan, dan tahap hasil pengamatan, dengan format penilaian teman sejawat, dan(4) penilaian domain kreativitas, yang diperoleh dari pemberian tugas mandiri yang dipresentasikan di depan kelas, penilaian domain ini diberikan oleh guru.

Berdasarkan kemampuan pedagogi guru matematika secara umum, maka dilakukan analisis kebutuhan di lapangan yaitu perlu di kembangkan suatu model pembelajaran dengan serangkaian kegiatan yang sesuai disertai dengan bahan ajar yang dapat digunakan oleh guru dan siswa dalam melaksanakan pembelajaran secara lebih baik lagi. Agar model pembelajaran ini dapat diterapkan sesuai dengan karakteristik siswa yang lebih memahami masalah berdasarkan apa yang ditemukan dalam kehidupan seharihari. Pendekatan yang dipilih dan peneliti anggap sesuai dengan kondisi, kebutuhan dan karakteristik siswa adalah pendekatan realistik.

Jadi, proses belajar matematika harus ditekankan pada konsep yang dikenal siswa. Setiap siswa mempunyai seperangkat pengetahuan yang telah dimilikinya sebagai akibat dari interaksi dengan lingkungan atau proses belajar sebelumnya. Setelah siswa terlibat dalam proses belajar yang bermakna, siswa mengembangkan lebih lanjut pengetahuan tersebut ke tingkat yang lebih tinggi. Dalam proses tersebut, siswa secara aktif memperoleh pengetahuan baru. Pembentukan pengetahuan adalah proses perubahan yang bergerak secara perlahan dari tingkat pertama ke tingkat kedua, kemudian ke tingkat ketiga. Dalam proses tersebut siswa bertanggung jawab terhadap aktivitas belajar yang dilaksanakannya.

Implementasi pembelajaran berbasis Pepro Kreasi dan dianalisis terhadap nilai ulangan siswa untuk setiap edisi (standar kompetensi), maka diperoleh nilai siswa yang berpatokan pada nilai diatas kriteria ketuntasan minimal (KKM). Nilai sikap, nilai proses, dan nilai kreativitas dikalkulasi untuk masing-masing siswa dan digabungkan menjadi sebuah nilai komposit untuk mendapatkan kategori untuk tiap domain. Maka dapat ditarik kesimpulan bahwa bahan ajar tersebut adalah layak dan efektif untuk diimplementasikan di sekitar lingkungan madrasah Tsanawiyah Al-Ishlahuddiny untuk 
dan gaya bahasa sederhana serta tidak kaku, solusi yang berisi kumpulan permasalahan yang berkaitan dengan materi yang sedang di bahas, eksplorasi yang berisi informasi tambahan yang sayang untuk dilewatkan, histori yang berisi asal-usul atau sejarah yang berkaitan dengan materi, deskripsi yang berisi informasi yang menyuguhkan manfaat yang dapat diperoleh dari materi, cerpen, dan game.

Pengembangan model pembelajaran matematika berbasis Pepro Kreasi, meliputi tiga bentuk, yaitu:

(1) Model konseptual merupakan perwujudan dari konseptualisasi teori-teori dan prinsipprinsip yang terintegrasi sedemikian rupa membentuk bahan ajar matematika berbasis Pepro Kreasi.

(2) Model prosedural merupakan perwujudan tahapan-tahapan pembentukan model pembelajaran matematika berbasis Pepro Kreasi.

(3) Model fisikal adalah hasil nyata berupa desain pembelajaran, 3buku pengayaan, dan pada materi geometri.

Model pembelajaran Matematika berbasis Pepro Kreasi dengan produk buku pengayaan, memiliki beberapa kelebihan dan kelemahan, yaitu:

\section{Kelebihan}

a. Buku pengayaan dibuat dalam ukuran A4 dan bentuk tidak terlalu tebal sehingga memudahkan untuk dibawa

b. Lay-out buku pengayaan pada bagian sampul dibuat dengan angka yang berbeda sehingga memberikan kemudahan bagi pengguna buku pengayaan dalam membedakan antara pokok bahasan satu dengan pokok bahasan yang lainnya.

c. Buku pengayaan dibuat dengan menggunakan bahasa yang sederhana dan setiap edisi memuat inspirasi (kisah tokoh-tokoh penting yang memberi inspirasi), Histori (asal-usul atau sejarah yang berkaitan dengan materi), simulasi (aksi seru sebagai pengantar materi yang akan di bahas), konsepsi (materi matematika yang disajikan dengan konsep dan gaya bahasa sederhana, serta tidak kaku), solusi (kumpulan permasalahan yang berkaitan dengan materi yang sedang dibahas), eksplorasi (informasi tambahan), deskripsi (informasi yang menyuguhkan manfaat yng dapat diperoleh dari materi), cerpen dan game.

d. Materi dalam buku pengayaan menggunakan pendekatan realistik, maksudnya setiap materi dikaitkan dengan contoh benda konkrit yang ada pada lingkungan sekitar atau masalah pada kehidupan sehari-hari.

e. Setiap edisi dalam buku pengayaan dilengkapi dengan tugas mandiri yang harus di paparkan atau di presentasikan di depan kelas.

f. Memberikan motivasi diri peserta didik dalam hal penilaian kegiatan, agar lebih aktif dan berpartisipasi dalam proses pembelajaran.

\section{Kelemahan}

a. Buku pengayaan yang dihasilkan merupakan buku penunjang untuk menambah wawasan peserta didik, jadi masih harus dilengkapi dengan bahan ajar lainnya, karena buku pengayaan ini didesain dengan aturan yang tidak baku yang berisi inspirasi, simulasi, konsepsi, solusi, eksplorasi, histori, deskripsi, cerpen dan game, serta gambar-gambar yang mendukung untuk meningkatkan minat siswa mempelajari materi matematika.

b. Dalam penilaiannya yang berbasis Pepro Kreasi, perlu persiapan yang lengkap, karena terlalu banyak format yang digunakan.

c. Menuntut profesionalisme guru karena mengamati peserta didik yang bervariasi, meskipun dalam penilaian dibantu siswa sebagai penilai, tetapi guru tetap harus memantau dan memverfikasi hasil penilaian siswa.

d. Sulit menyamakan persepsi karena latar belakang yang berbeda.

e. Hasil Penilaian sangat tergantung situasi yang sedang dialami peserta didik sehingga hasilnya berpeluang berbeda.

Pengembangan model pembelajaran matematika berbasis Pepro Kreasiini merupakan upaya dalam memfasilitasi pembelajaran agar tercipta pembelajaran yang efektif, efisien, dan menarik sehingga meningkatkan kompetensi, minat, dan hasil belajar matematika siswa.

\section{PEMBAHASAN}

Penelitian mengenai pengembangan 
$75 \%$. Dari penilaian kelima domain dalam Pepro Kreasi tersebut (domain pengetahuan dan aplikasi, domain sikap, domain proses, dan domain kreativitas) diperoleh nilai di atas standar, hanya terdapat $10 \%$ dalam domain pengetahuan dan aplikasi yang dinyatakan tidak tuntas.

Hasil pengembangan dari penelitian ini berupa "buku pengayaan untuk Pembelajaran matematika kelas VII semester genap" yang disebut sebagai produk. Sedangkan isi model pembelajaran ini meliputi:

1. Desain model konseptual, dan model prosedural pembelajaran matematika berbasis Pepro Kreasi.

2. Buku pengayaan yang terdiri dari buku 1 sampai buku 3 sesuai dengan Standar Kompetensi (SK) yang ada pada kelas VII semester genap, namun materi yang perkaya adalah materi geometri.
Desain bahan ajar dengan format tampilan penulisan yang tidak baku dan isi sesuai dengan kebutuhan kurikulum sekolah yang ingin diperkaya, di dalamnya disisipi gambar yang mendukung materi yang sedang dibahas dan menggunakan bahasa yang tidak kaku. Desain buku pengayaan dibagi menjadi tiga edisi; (1) edisi pertama, siswa diajak untuk memahami hubungan garis, garis dengan garis, garis dengan sudut, serta menentukan ukurannya, (2) edisi kedua, siswa diajak untuk memaham konsep segiempat yang meliputi sifat-sifatnya, kelilingnya, dan luasnya, dan (3) edisi ketiga, siswa diajak untuk memahami konsep segitiga dan cara melukis garisgaris pada segitiga.

Adapun dalam setiap edisi masing-masing dilengkapi dengan tema; inspirasi yang berisi kisah tokoh-tokoh penting yang memberi inspirasi, simulasi yang berisi aksi seru sebagai pengantar materi yang akan dibahas, konsepsi yang berisi materi matematika yang disajikan dengan konsep

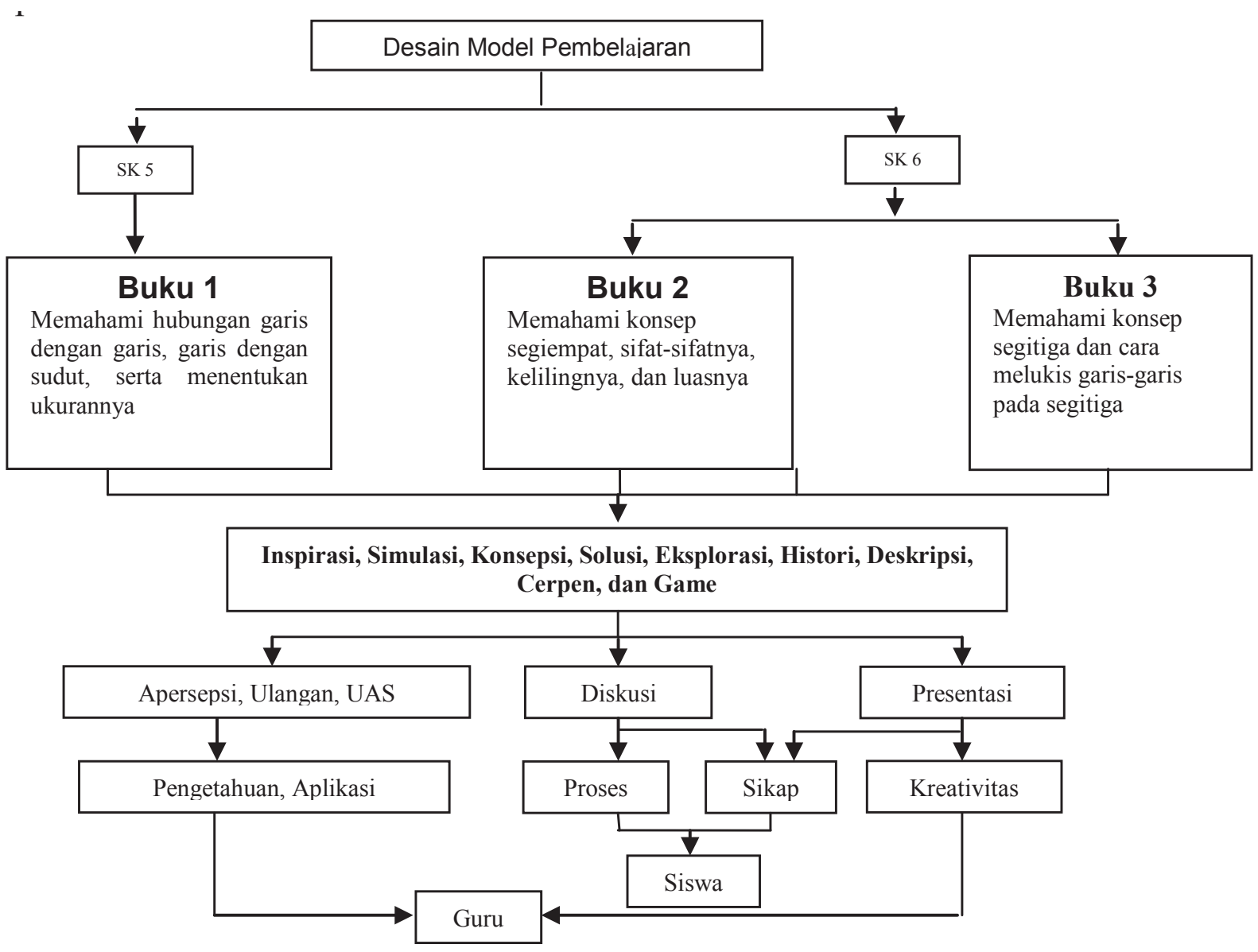

Gambar 1. Desain Model Pembelajaran 
dan melaksanakan evaluasi sumatif.

Hasil pengembangan produk dilakukan melalui uji formatif, yaitu: uji ahli, uji one to one, uji kelompok kecil, dan uji lapangan. Selanjutnya, masukan dari hasil uji coba lapangan menjadi dasar terakhir bagi perbaikan dan penyempurnaan produk. Setelah diperbaiki sesuai masukan dari lapangan, maka produk dianggap final dan siapuntuk disebarkan atau digunakan secara massal. Untuk mengetahui keberhasilan implementasi kalau model akan dilaksanakan, maka perlu dilakukan sebuah evaluasi sumatif yaitu setelah pemanfaatan produk berjalan selama periode tertentu, untuk menilai efektif dan efisien suatu produk, untuk menilai apakah produk efektif dan efisien atau tidak. Hal ini berkaitan dengan pengambilan keputusan untuk menentukan apakah pengembangan model tersebut diteruskan atau tidak. Evaluasi pada tahap ini disebut dengan evaluasi sumatif. Tetapi dalam penelitian ini evaluasi sumatif tidak dilakukan disebabkan keterbatasan waktu penelitian.

Penelitian ini dilakukan selamasatu semester, yakni mulai bulan januari 2013 sampai bulan Mei 2013.Untuk mengetahui efektivitas produk dilakukan uji ahli yaitu ahli materi, ahli media pembelajaran, dan ahli desain instruksional, uji one to one kepada 6 orang yang memiliki yang memiliki kemampuan sedang, tinggi, dan rendah, yang dilihat dari nilai raport semester ganjil, uji kelompok kecil kepada 10 orang siswa yang dipilih secara acak, dan uji lapangan kepada 30 orang siswa kelas VII madrasah Tsanawiyah Putra Al-Ishlahuddiny.

\section{HASIL PENELITIAN}

Penelitian yang dilakukan menghasilkan temuan dalam hal kemampuan guru dalam melaksanakan evaluasi pembelajaran matematika di madrasah Tsanawiyah Al-Ishlahuddiny. Guru memiliki pengetahuan yang minim mengenai konsep dasar penilaian hasil belajar. Penilaian hasil belajar peserta didik merupakan sesuatu yang sangat penting dan strategis dalam kegiatan belajar mengajar.

Dengan penilaian hasil belajar maka dapat diketahui seberapa besar keberhasilan peserta didik telah menguasai kompetensi atau materi yang telah diajarkan oleh guru. Melalui penilaian juga dapat dijadikan acuan untuk melihat tingkat keberhasilan atau efektivitas guru dalam pembelajaran. Oleh karena itu, penilaian hasil belajar harus dilakukan dengan baik mulai dari penentuan instrumen, penyusunan instrumen, telaah instrumen, pelaksanaan penilaian, analisis hasil penilaian dan program tindak lanjut hasil penilaian.

Penilaian hasil belajar yang baik akan memberikan informasi yang bermanfaat dalam perbaikan kualitas proses belajar mengajar. Sebaliknya, kalau terjadi kesalahan dalam penilaian hasil belajar, maka akan terjadi salah informasi tentang kualitas proses belajar mengajar dan pada akhirnya tujuan pendidikan yang sesungguhnya tidak akan tercapai.

Kedua, nilai yang diberikan seorang guru kepada peserta didik tidak dapat diperbandingkan dengan nilai yang diperoleh dari guru lainnya. Artinya penilaian yang diberikan oleh guru kepada peserta didik seringkali memiliki perbedaan antara guru yang satu dengan guru yang lainnya.

Ketiga, hasil penilaian yang dilakukan oleh guru terkadang belum sepenuhnya menggambarkan pencapaian kompetensi riil dari peserta didik, sehingga peserta didik yang sudah dinyatakan menguasai kompetensi, misalnya kompetensi dasar (KD) tertentu, ternyata sesungguhnya belum menguasai kompetensi dasar tersebut. Hal ini bisa dilihat dari fakta bahwa ketika peserta didik sudah dikatakan tuntas dari suatu KD dalam ulangan harian (formatif), tetapi ketika diuji lagi untuk KD tersebut dalam Ujian Tengah Semester (UTS) atau ujian lainnya, peserta didik mengalami kesulitan dalam menguasai KD tersebut. Hal ini berarti informasi hasil penilaian oleh guru melalui kegiatan penialain adalah informasi yang kurang valid dan kurang akurat. Dampak dari kurang akuratnya hasil penilaian, maka yang dirugikan adalah peserta didik.

Hasil gabungan penilaian domain proses, sikap, dan kreativitas diperoleh 10 siswa yang mendapat nilai dengan kategori A atau Amat baik, jika dipersentasikan maka terdapat 3,33\% siswa yang mendapat nilai dengan kategori sangat baik. Sedangkan 20 siswa atau sebanyak $66,7 \%$ siswa mendapat nilai dengan kategori baik.

Selanjutnya jika nilai komposit tersebut di sesuaikan dengan penetapan standar nilai Kriteria Ketuntasan Minimal (KKM) yaitu 70, maka semua siswa termasuk dalam kategori tuntas.

Jadi, berdasarkan teori yang telah dipaparkan pada bab III bahwa pembelajaran itu dikatakan berhasil jika memenuhi kriteria ketuntasan sebanyak 
(majalah Ar-Rhiyadhiyat, atau majalah Matematika). Konten dari Mardhi berbeda dengan buku sumber belajar lainnya. Dari segi tampilan, Mardhi di desain sederhana dengan berbagai ilustrasi yang menggambarkan materi. Dari segi bahasa, Mardhi menggunakan bahasa sederhana, familiar, dan tidak kaku, yaitu bahasa yang sering digunakan siswa dalam kehidupan sehari-hari.

Dalam konteks teknologi pembelajaran menurut Miarso (2009: 8), bahwa sumber belajar merupakan segala sesuatu yang dapat digunakan anak didik untuk belajar, baik yang secara khusus dirancang untuk itu maupun yang secara alamiah tersedia di lingkungan setempat untuk dipakai. Sumber ini tidak hanya merupakan sesuatu yang disediakan oleh Departemen Pendidikan dan Kebudayaan saja, apalagi oleh guru kelas saja, melainkan juga sumber yang ada dan dapat digali dari masyarakat. Dengan kata lain, sumber belajar merupakan komponen sistem pembelajaran yang merupakan sumber-sumber belajar yang dirancang terlebih dahulu dalam proses desain atau pemilihan dan pemanfaatan, dan dikombinasikan menjadi sistem pembelajaran yang lengkap untuk mewujudkan terlaksananya proses belajar yang bertujuan dan terkontrol. Teknologi pembelajaran berupaya untuk merancang, mengembangkan, engorganisasikan dan memanfaatkan aneka sumber belajar sehingga dapat memudahkan atau menfasilitasi seseorang untuk belajar.

Artikel ini membahas hasil penelitian pengembangan sebagai upaya untuk meningkatkan hasil belajar siswa dengan pendekatan penilaian Pepro Kreasi Adapun tujuan penelitian ini adalah menghasilkan produk bahan ajar dan instrumen penilaian berbasis Pepro Kreasi bagi siswa kelas VII semester genap, khususnya di madrasah Tsanawiyah Putra Al-Ishlahuddiny.

\section{METODE PENELITIAN}

Joyce dan Weil (2002: 104) mengemukakan bahwa, model pembelajaran adalah suatu rencana atau suatu pola yang digunakan untuk merancang pembelajaran setiap tatap muka di kelas atau dalam tutorial, dan untuk menentukan perangkat pembelajaran termasuk buku, film tape (rekaman), program yang dimediasi komputer dan kurikulum. Setiap model mengarahkan kita untuk mendesain pembelajaran guna membantu siswa sehingga tujuan pembelajaran tercapai. Selanjutnya Joyce dan Weil mengemukakan bahwa model pembelajaran mempunyai unsur: (1) sintaks; (2) sistem sosial; (3) prinsip-prinsip reaksi; (4) sistem pendukung; (5) dampak instruksional; dan (6) dampak pengiring.

Penelitian ini bertujuan untuk mengembangkan sesuatu yang baru dan diharapkan dapat meningkatkan kualitas hasil belajar matematika siswa. Keterampilan yang akan dikembangkan dalam penelitian ini adalah kemampuan untuk menyelesaikan masalah dalam kehidupan sehari-hari yang dituangkan dalam model matematika sehingga hasilnya dapat di presentasikan di depan kelas.

Penelitian ini menggunakan metode penelitian dan pengembangan yang dikolaborasikan dari model pengembangan yang dikemukakan oleh Gall \& Borg (2007:589) dan model pengembangan Dick \& Carey. Diawali dengan penelitian pendahuluan yang pengumpulan datanya dilakukan melalui wawancara, dan angket. Wawancara dilakukan terhadap 5 orang guru, konteks wawancara berhubungan dengan kegiatan pembelajaran di kelas, kemampuan dan minat siswa terhadap pelajaran matematika, dan kelengkapan administrasi guru. Pengisian angket dilakukan oleh 7 orang guru yang mengajar matematika di madrasah Tsanawiyah AlIshlahuddiny.

Berdasarkan analisis kebutuhan dari temuan penelitian pendahuluan, kemudian dikembangkan model pembelajaran matematika berbasis Pepro Kreasi yang ditunjang dengan produk berupa buku pengayaan. Desain pembelajaran dalam pengembangan model ini mengikuti langkah-langkah dalam Model Dick \& Carey. Dalam model Dick \& Carey menurut Suparman (2000: 132) dibagi atas tiga tahapan. Adapun tahapan-tahapan tersebut adalah sebagai berikut: (a) Tahap mengidentifikasi, terdiri dari; 1) mengidentifikasi kebutuhan pembelajaran dan menulis tujuan pembelajaran umum, 2) melakukan analisis pembelajaran, dan 3) mengidentifikasi perilaku dan karakteristik siswa. (b) Tahap mengembangkan, terdiri dari; 1) menulis tujuan pembelajaran khusus, 2) menulis tes acuan patokan, 3) menyusun strategi pembelajaran, dan 4) mengembangkan bahan pembelajaran. (c) Tahap mengevaluasi atau merevisi, yang terdiri dari; 1) Mendesain dan melaksanakan evaluasi formatif yang termasuk didalamnya kegiatan merevisi, 2) merevisi kegiatan pembelajaran, dan 3) mendesain 
dipaparkan disebabkan oleh beberapa faktor, salah satu diantaranya adalah kurang tersedianya bahan ajar yang dapat dijadikan pedoman. Kalaupun tersedia, bahan ajar tersebut belum disertai dengan contoh nyata dalam pembelajaran sebagaimana dikehendaki para guru, dengan kata lain minimnya ketersediaan bahan ajar yang praktis dan aplikatif sebagaimana dibutuhkan guru. Oleh karena itu, bahan ajar yang tersedia nampaknya belum dapat digunakan secara maksimal.

Upaya peningkatan kualitas pembelajaran harus dilakukan secara komprehensif, tidak hanya ditinjau faktor guru, siswa, bahan ajar, tetapi juga dari kurikulum. Baik buruknya kualitas pendidikan juga dipengaruhi oleh kurikulum. Kurikulum perlu ditinjau agar dapat menyesuaikan dengan kebutuhan masyarakat. Hal ini perlu dilakukan mengingat perkembangan masyarakat yang semakin cepat, sementara tinjauan kurikulum dilakukan tidak secepat perkembangan masyarakat.

Sarana dan prasarana dalam hal ini menjadi penunjang pendidikan yang juga perlu mendapat perhatian. Sarana dan prasarana yang menunjang pendidikan belum dirasakan oleh semua sekolah, khususnya sekolah swasta. Masih banyak sekolah yang mengalami kekurangan sarana dan prasarana untuk memperlancar proses pendidikan dan pembelajaran.

Penelitian yang relevan dengan menerapkan domain dalam sains telah dilakukan oleh Moh. Ali Maghfuri dengan melihat pengaruh model pembelajaran sains dan kemampuan memori siswa terhadap prestasi belajar kimia. Hasil penelitian yang diperoleh dikelompokkan dalam dua ranah, yaitu kognitif dan afektif. Prestasi belajar kimia siswa yang dilihat dari kedua ranah tersebut, menunjukkan bahwa model pembelajaran yang menerapkan domain sains memberikan pengaruh yang signifikan jika dibandingkan dengan pembelajaran konvensional.

Perubahan kurikulum mungkin dapat dibuat secara paralel dengan pembelajaran yang tepat untuk siswa dan guru tentang pengetahuan mengenai sistem penilaian dalam pembelajaran. Kesulitan-kesulitan yang terjadi dalam melaksanakan pembelajaran dan penilaian, perlu dikembangkan sistem pendidikan tepat untuk mengatasi semua karakteristikkarakteristik dan perbedaan individual yang ada pada siswa.

Uraian tentang beberapa faktor yang mempengaruhi rendahnya kualitas pembelajaran semakin lengkap dengan penggunaan metode pembelajaran yang tidak efektif dan efisien pada suatu materi atau pelajaran tertentu. Menurut Yager (2002: 58) bahwa metode pembelajaran yang dilakukan saat ini dalam pembelajaran matematika belum memiliki model pembelajaran yang efektif dan efisien. oleh karena itu lebih lanjut Yager menyatakan bahwa melalui model pembelajaran matematika berbasis "Pepro Kreasi" yaitu pembelajaran dengan menerapkan lima domain dalam sains yang terdiri dari Pengetahuan (knowledge), Proses (processes), Kreativitas (creativity), Aplikasi (application), dan Sikap (attitude), maka sekaligus dapat diterapkan konsep-konsep psikologi perkembangan dan optimalisasi otak kanan (brain theory) yang menghendaki siswa untuk belajar secara kongkret dan mengembangkan kemampuan berpikir divergen (berpikir menyelesaikan masalah dengan banyak alternatif untuk menumbuhkan kreativitas, inovasi, dan imajinasi konstruktif), sehingga siswa diharapkan memiliki pemahaman konsep dasar matematika yang baik agar mampu mengaitkan dengan materi yang akan dibahas selanjutnya.

Orientasi dari perumusan kurikulum 2013 bahwa semua mata pelajaran harus berkontribusi terhadap pembentukan sikap, keterampilan, dan pengetahuan. Perumusan kurikulum tersebut menurut Kunandar (2003: 30) merupakan penyempurnaan pola pikir dari kurikulum KTSP yang memberikan pemisahan antara mata pelajaran pembentuk sikap, pembentuk keterampilan, dan pembentuk pengetahuan. Sedangkan penilaian dalam model pengembangan berbasis Pepro Kreasi lebih luas menilik pada penilaian proses yang dilaksanakan selama pembelajaran berlangsung, dan bagaimana siswa mengembangkan kreativitas dari beberapa konsep yang telah dimiliki.

Pengembangan model pembelajaran matematika berbasis Pepro Kreasi menggunakan kurikulum KTSP, dimana kompetensi lulusan diturunkan dari standar isi, namum lebih luas menerapkan penilaian autentik sesuai dengan perumusan kurikulum 2013, khususnya mata pelajaran matematika berkontribusi bukan saja terhadap pembentukan sikap, keterampilan, dan pengetahuan, tetapi juga terhadap proses, aplikasi, dan kreativitas.

Produk yang dihasilkan berupa bahan ajar yang didesain berbentuk majalah, dan diberi nama Mardhi 
belajar matematika, hasil pembelajaran yang rendah juga dipengaruhi oleh faktor waktu, kurikulum, bahkan juga sumber daya manusia (guru). Siswa pada sebuah madrasah memiliki kegiatan informal di luar sekolah yang cukup padat, diantaranya kegatan diniyah. Semua mata pelajaran dan kegiatan menuntut siswa untuk memperoleh hasil maksimal yang diharapkan guru. Sementara jika ditinjau dari tingkat usia, anak pada tahap perkembangan ini masih membutuhkan waktu bermain dengan teman sebayanya. Sehingga siswa merasa kesulitan dalam mengatur waktu yang tersedia.

Faktor lain yang tidak kalah pentingnya untuk diperhatikan adalah sumber daya manusia, khususnya guru yang langsung terjun dalam dunia pendidikan. Bagaimana profesionalitas guru dalam menyelenggarakan pendidikan dan pembelajaran perlu dikaji. Hal ini mengingat salah satu kemungkinan penyebab kegagalan pendidikan adalah faktor guru sebagai pemegang peran utama dalam penyelenggaraan pendidikan dan pembelajaran di sekolah.

Profesionalitas guru diperkuat oleh data yang dipeoleh dari hasil sharing dengan teman sejawat dilakukan untuk memperoleh model pembelajaran matematika yang sesuai dengan kondisi guru dan siswa. Hasil sharing dengan teman sejawat/guru diperoleh masukan bahwa materi matematika hanya dipahami siswa secara prosedural. Hal ini disebabkan banyaknya rumus yang harus dikuasai oleh siswa. Selain itu dalam pembelajaran di kelas, guru mengalami kesulitan dalam memberikan contoh yang sesuai dengan masalah yang dihadapi siswa dalam kehidupan sehari-harinya. Menurut guru, berdasarkan hasil belajar selama ini yang dapat dilihat dari nilai raport semester sebelumnya, kemampuan belajar matematika siswa berada pada kategori rendah dengan rata-rata nilai klasikal 6 .

Fakta bahwa profesionalisme yang diukur dari kualitas kinerja guru tergambar dari hasil kajian yang dilakukan oleh Kementerian Pendidikan dan Kebudayaan RI tentang uji kompetensi guru. Hasil uji kompetensi terhadap guru yang telah bersertifikat, faktanya ternyata masih di bawah standar kompetensi yang diharapkan. Menurut Gultom (2012) bahwa nilai rata-rata nasional hasil perhitungan uji kompetensi per 1 Juli 2012 adalah 47,84. Berdasarkan hasil studi BERMUTU (2012: 23) dengan skala nilai 5,0 - 95,0, maka hasil uji kompetensi guru tersebut terindikasi masih berada di bawah rata-rata nasional. Hal ini menunjukkan, bahwa angka tersebut masih belum memperlihatkan posisi kualitas penguasaan standar kompetensi guru sebagaimana diharapkan. Padahal, sertifikasi guru sudah berjalan enam tahun saat dilakukan uji kompetensi. Sebagaimana diketahui, berdasarkan Peraturan Pemerintah nomor 19 (2005: 13) bahwa standar yang harus dimiliki guru sebagai agen pembelajaran pada jenjang pendidikan dasar dan menengah serta pendidikan anak usia dini meliputi: a) kompetensi pedagogik; b) kompetensi kepribadian; c) kompetensi profesional; dan d) kompetensi sosial. Dapat diasumsikan, masih rendahnya kualitas standar kompetensi yang dimiliki guru berdampak kepada rendahnya kualitas perencanaan, pelaksanaan, dan pengevaluasian hasil pembelajaran yang dilakukan guru.

Hasil wawancara dengan siswa Madrasah Tsanawiyah Al-Ishlahuddiny Kediri diketahui bahwa model pembelajaran matematika yang ada belum dapat memberikan pengetahuan konseptual secara optimal.Strategi dan metode yang digunakan belum menimbulkan ketertarikan siswa untuk lebih memahami matematika. Pembelajaran matematika hanya berisi materi yang disusun secara monoton untuk tiap kali pertemuan di kelas formal sehingga membosankan bagi siswa. Dengan kata lain bahwa proses belajar mengajar yang diterapkan guru belum mengacu pada standar pembelajaran yang jelas.

Kalau kita bertanya kepada siswa di sekolah tentang mata pelajaran yang paling tidak disukai, 75\% menjawab mata pelajaran matematika. Penjelasan yang diberikan guru hanya dapat di mengerti pada saat penjelasan tersebut diberikan di kelas, tetapi ketika siswa sampai di rumah mereka sudah lupa. Hal ini menunjukkan mereka belum mengerti dengan pengetahuan konseptual. Mereka hanya mengerti pengetahuan prosedural.

Ada $60 \%$ siswa mengatakan bahwa guru mengajar matematika (khususnya di Madrasah Tsanawiyah Al-Ishlahuddiny) umumnya menggunakan metode teacher oriented. Siswa kurang diberi contoh mengenai aplikasi dan manfaat materi, sehingga materi matematika akhirnya hanya diserap siswa secara abstrak. Seharusnya guru mampu menghidupkan suasana belajar, sehingga siswa tidak hanya diam sebagai pendengar saja.

Kekurangmampuan guru dalam meningkatkan minat siswa belajar matematika sebagaimana 


\title{
Pengembangan Model Pembelajaran Matematika Berbasis Pepro Kreasi Di Madrasah Tsanawiyah
}

\begin{abstract}
Mutmainnah*
Abstract: The development of mathematical learning models based on Pepro Kreasi at junior high boarding school. This study aims to develop instructional mathematics models based on Pepro Kreasi (Knowledge, Processes, Creativity, Activity, and Attitude)that can increase the competencies, interest, and student learning outcomes. In edition to using lesson matter book, as well as using assessment instrument.Development of instructional models followed the Dick \& Carey model.this study result the design of instructional, learning resources book that we call Mardhi (mathematics magazine), and the user guide for teacher and student that .Formative test that involved expert testing, one-to-one, small group, and field test, were carried out and resulted in conceptual, procedural, and physical models for the development of viable and effective instructional mathematics models to be used in AlIshlahuddiny junior boarding high school.
\end{abstract}

Keywords: mathematic instructional, models, lesson matter, assessment instrument, and pepro kreasi.

Abstrak: Tujuan penelitian ini menghasilkan model pembelajaran matematika berbasis Pepro Kreasi (Pengetahuan, Proses, Kreativitas, Aplikasi, dan Sikap) yang dapat meningkatkan kompetensi, minat dan hasil belajar siswa. Selain menggunakan bahan ajar, digunakan juga instrumen penilaian dalam kegiatan pembelajaran. Metode yang digunakan dalam Research and Development adalah model pengembangan Dick \& Carey. Hasil penelitian ini adalah desain pembelajaran, bahan ajar yang disebut sebagai Mardhi (majalah Ar-Riyadhiyat), dan buku panduan penggunaan untuk guru dan siswa. Uji coba formatif berupa uji ahli, uji One-to-one, uji kelompok kecil, dan uji lapangan. Penelitian ini menghasilkan model konseptual, prosedural, dan fisikal, yang telah teruji efektivitas, efisiensi dan kelayakannya untuk pembelajaran matematika yang digunakan di madrasah Tsanawiyah Al-Ishlahuddiny.

Kata kunci: pembelajaran matematika, model, bahan ajar, instrumen penilaian, pepro kreasi.

\section{PENDAHULUAN}

Kurikulum tentang belajar matematika menurut Chambers (2008: 88) lebih menekankan untuk memanfaatkan konteks cerita dan kebiasaan siswa, sehingga dalam pembelajaran matematika, penggunaan konteks kehidupan sehari-hari juga dianjurkan untuk diterapkan pada lingkungan belajar siswa.

Matematika yang merupakan bagian dari sains adalah suatu sistem yang kompleks yang terdiri dari banyak domain yang saling berkaitan namun memiliki karakter yang berbeda-beda. Oleh karena itu, tidak ada suatu metode, pendekatan, model ataupun strategi pembelajaran yang paling baik untuk pembelajaran matematika. Suatu pendekatan ataupun metode mungkin hanya bermanfaat untuk pembelajaran suatu konsep tertentu pada level yang tertentu juga.

Selain faktor kurangnya minat siswa dalam

* Mutmainah, Program Studi Teknologi Pendidikan, Jalan Rawamangun Muka Gd.M, Program Pascasarjana, Universitas Negeri Jakarta, Jakarta Timur.muti250281@yahoo.com 


\section{DAFTAR PUSTAKA}

Blanchad, P. Nick \& James W. Thacker. Effective Training: Systems, Strategies, and Practices, Third Edition. New Jersey: Pearson Prentice Hall. 2007.

Flamholtz, Eric and Yvonne Randle. Leading Strategic Change: Bridging Theory and Practice. Newyork: Cambridge University Press. 2008.

Gagne, Robert M., et al. Principles of Instructional Design, Fifth Edition. Belmont: Thomson Wadsworth. 2005.

Heifz, Ronald, A. Grashow, and M. Linsky. The Practice of Adaptive Leadership. Massachusetts: Harvard Business School Publishing. 2009.

Kirkpatrick, D. L \& Kirkpatrick, J.D., Evaluating Training Program, (San Francisco, USA: Berret-Koehler Publisher, Inc. 2005.

,Transfering Learning to Behaviour: Using the Four Level to Improve Performance. Sanfrancisco:: Berret-Koehler Publisher Inc, 2005.

Laird, Dugan. Approaches to Training and Development: New Perspectives in Organizational Learning, Performance, and Change, Cambridge: Perseus Publishing. 2003.

Miles, Matthew B. \& A. Michael Huberman. Analisis Data Kualitatif. terjemahan Tjetjep Rohendi Rohidi. Jakarta: UI-Press. 2009.

Mujiman, Haris. Manajemen Pelatihan Berbasis Belajar Mandiri. Yogyakarta: Pustaka Pelajar. 2011.

Patton, Michael Quinn. Metode Evaluasi Kualitatif, terjemahan Budi Puspo Priyadi. Yogyakarta: Pustaka Pelajar 2009.

Pribadi, Benny P. Desain dan Pengembangan Program Pelatihan Berbasis Kompetensi: Implementasi Model ADDIE. Jakarta: Prenada Media Group. 2014.

Sedarmayanti. Manajemen Sumber Daya Manusia: Reformasi Birokrasi dan Manajemen Pegawai Negeri Sipil. Bandung: Refika Aditama.2013

Sitepu. Penulisan Buku Teks Pelajaran. Bandung: Remaja Rosdakarya. 2012.
Subrahmanian, Mu. "Evaluating Training Programmes in India Post", Researchers World: Journal of Arts Sciences \& Commerce, Vol-I, Issue-1, October 2010.

Suparman, M. Atwi. Desain Instruksional Modern: Panduan Para Pengajar dan Inovator Pendidikan. Jakarta: Erlangga. 2012.

Supranto. Pengukuran Tingkat Kepuasan Pelanggan: untuk Menaikkan Pangsa Pasar. Jakarta: Rineka Cipta. 2011.

Sukardi. Evaluasi Program Pendidikan dan Kepelatihan. Jakarta: Bumi aksara. 2014.

Thoha, M. Chabib. Teknik Evaluasi Pendidikan. Jakarta: PT. RadjaGrafindo Persada. 2003.

Thoha, Miftah, Manajemen Kepegawaian Sipil di Indonesia, Jakarta: Kencana Prenada Media Group, 2005.

Wang, Victor C. X. Assessing and Evaluating Adult Learning in Career and Technical Education. Hershey: Zhejiang University Press. 2011.

Widoyoko, S. Eko Putro. Evaluasi Program Pembelajaran: Panduan Praktis bagi Pendidik dan Calon Pendidik. Yogyakarta: Pustaka Pelajat. 2012. 
diklat. Penilaian penerapan perilaku yang diperoleh selama diklat difokuskan pada nilai-nilai integritas, etika publik, kedisiplinan, dan kerja sama. Keempat nilai tersebut menjadi bagian dari penilaian hasil diklat. Perubahan kompetensi perubahan perilaku tersebut lebih bermakna apabila dapat bermanfaat dan mendukung pelaksanaan tugas peserta pada instansinya masing-masing. Hal tersebut diakui oleh peserta diklat dengan penjelasan bahwa mendukung pelaksanaan tugas di eselon IV terutama dalam meningkatkan inovasi kreativitas dan motivasi kerja, mendukung kepastian percepatan kegiatan, ketepatan sasaran kegiatan, serta hasil kegiatan. Terjadi peningkatan bobot kualitas. Adanya kemampuan mengaktualisasikan integritas pribadi terhadap tugas. Mempermudah pelaksanaan tugas-tugas karena ada pengetahuan dan pengalaman dalam melaksanakan koordinasi, konsultasi, dan lainnya.

Penerapan keterampilan di tempat kerja setelah diklat diukur dari keterampilan kepemimpinan oerasional terutama dalam melakukan perubahan pada unit kerjanya. Banyak perubahan yang dilakukan oleh peserta diklat terutama dilihat dari sisi keterampilan kepemimpinan. Keterampilan yang didapatkan selama diklat tentu kurang bermakna jika tidak diterapkan pada unit kerjanya. Pengakuan beberapa peserta mengenai keterampilan yang agak sulit diterapkan diinstansinya adalah keterampilan koordinasi, komunikasi, dan membangun tim yang solid serta efektif. Kesulitan penerapannya sangat bergantung pada jenis tugas dan kemampuan peserta.

\section{Evaluasi Hasil}

Evaluasi hasil mengukur tingkat program diklat telah membantu pencapaian tujuan organisasi yang telah ditetapkan sebelumnya dan berdampak kepada peningkatan kinerja organisasi. Aspek yang dievaluasi pada level hasil diklat adalah mulai dari tujuan diklat dan perannya terhadap kompetensi kepemimpinan, peningkatan kualitas kerja dan hasil kerja, penciptaan iklim kerja, kualitas layanan, dan tingkat kepercayaan masyarakat terhadap organisasi.

Transfer pembelajaran menuju hasil diklat dipengaruhi oleh interaksi kompleksitas beberapa variabel. Terdapat tiga faktor utama yang mempengaruhi kemungkinan tranfer pembelajaran kepada hasil, yaitu; ability to use, motivation to use, and the work environment (Wick, C., Roy P., \& Andrew J., 2010: 176). Kemampuan peserta menerapkan pembelajaran dengan mempertimbangkan: kapasitas peserta membuat perubahan, situasi kerja memberikan kesempatan menerapkan hasil belajar, hasil pembelajaran yang relevan, pemikiran untuk dapat diterapkan. Motivasi menyangkup kepercayaan menerapkan keterampilan baru untuk meningkatkan kinerja, penghargaan atas penerapan keterampilan baru, serta keberterimaan nilai-nilai. Hal lain yang mempengaruhi motivasi adalah kepercayaan diri peserta dan kesiapan berpartisipasi pada diklat. Lingkungan kerja meliputi pengaruh manajer, kelompok sebaya, dan sistem penghargaan.

\section{KESIMPULAN}

Berdasarkan hasil penelitian dan pembahasannya, dapat diambil kesimpulan sebagai berikut: (1) Reaksi peserta diklat terhadap aspek kurikulum, tenaga kediklatan, dan fasilitas diklat berada pada kategori memadai. Kurikulum Diklat sepenuhnya mengacu kepada Perkalan Nomor 13 Tahun 2013 serta telah memenuhi kualitas dan harapan peserta diklat. Hal tersebut tercermin dari penilaian peserta terhadap pengaturan jadwal diklat, pengembangan materi diklat, pengembangan metode pembelajaran, pengembangan media pembelajaran, kegiatan benchmarking ke best practice, dan pelaksanaan laboratorium kepemimpinan. Tenaga kediklatan yang meliputi penyelenggara, widyaiswara, narasumber, coach, dan mentor telah melaksanakan tugasnya dengan baik dan sesuai dengan kriteria dan harapan peserta. Fasilitas diklat cukup memadai dalam mendukung proses penyelenggaraan diklat, mencakup ruang kelas, asrama, sarana pendukung, dan konsumsi. (2) Pembelajaran Diklat Kepemimpinan Tingkat IV untuk meningkatkan kompetensi kepemimpinan operasional telah tercapai. Hal tersebut terlihat dari nilai akhir peserta diklat dengan rata-rata 81,25 dan sesuai kriteria kualifikasi kelulusan peserta diklat berada pada kategori memuaskan. (3) Terjadi perubahan perilaku peserta setelah mengikuti Diklat Kepemimpinan Tingkat IV. Penambahan pengetahuan dan keterampilan serta perubahan sikap perilaku sebagai hasil diklat telah dapat diaplikasikan pada unit kerjanya. (4) Hasil Program Diklat Kepemimpinan Tingkat IV Pemerintah Provinsi NTB Pemenuhan kompetensi bagi peserta diklat terhadap hasil diklat berdampak terhadap peningkatan kinerja instansi khususnya pada aspek pelayanan publik. 


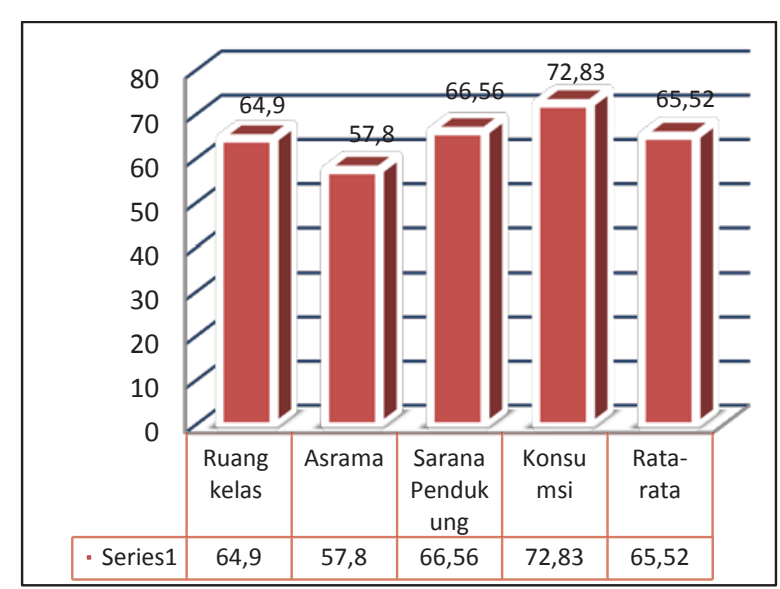

Gambar 3. Reaksi Peserta terhadap Aspek Fasilitas

Hasil analisis kuesioner pada aspek fasilitas diklat terhadap empat komponen yaitu ruang kelas, asrama, sarana pendukung, dan konsumsi menunjukkan bahwa tingkat keberhasilan atau efektivitas program dari segi reaksi peserta adalah berada pada skor 65,52 atau pada kategori memadai. Hasil selengkapnya seperti terlihat pada gambar di bawah ini,

\section{Evaluasi Pembelajaran}

Evaluasi pembelajaran dimaksudkan untuk mengukur peningkatan pengetahuan, sikap, dan keterampilan yang diperoleh sebagai hasil diklat. Hasil diklat diketahui selama proses penyelenggaraan berlangsung melalui mekanisme penilaian yang diatur dalam Perka LAN nomor 13 tahun 2013 dan telah diubah dalam Perka LAN No. 22 Tahun 2014. Penilaian akhir peserta diperoleh melalui nilai pada saat seminar I (perencanaan inovasi) dan seminar II (manajemen perubahan). Indikator dan bobot penilaian setiap seminar menunjukkan kompetensi yang dibangun sesuai tujuan diklat yaitu kompetensi kepemimpinan operasional yang merupakan kemampuan membuat perencanaan kegiatan dan memimpin keberhasilan implementasi pelaksanaan kegiatan tersebut.

Peserta Diklat Kepemimpinan Tingkat IV Angkatan II dengan kualifikasi kelulusan yaitu sebanyak 22 orang atau $73 \%$ termasuk kategori memuaskan dan 8 orang atau $27 \%$ termasuk kategori cukup memuaskan. Peserta diklat angkatan III dengan kualifikasi memuaskan sebanyak 16 orang atau $53 \%$ dan 14 orang atau $47 \%$ mendapatkan kategori cukup memuaskan. Hal tersebut berarti jumlah peserta yang mendapatkan kategori kelulusan memuaskan pada angkatan II dan III adalah sebanyak 38 orang atau $63 \%$ dan kategori cukup memuaskan sebanyak 22 orang atau $37 \%$. Rentang nilai kategori memuaskan adalah antara $>80,00-90,00$, sedangkan kategori cukup memuaskan berada pada antara nilai $>70,00-80,00$.

Inti kompetensi kepemimpinan dalam diklat kepemimpinan adalah membentuk pemimpin perubahan. Filosofi pemimpin perubahan ini diilhami oleh konsep kepemimpinan adaptif (adaptive leadership) yang dikembangkan oleh Heifetz (2009: 14). Adaptive leadership is the practice of mobilizing people to tackle tough challenges and thrive. Kebutuhan perlunya pemimpin adaptif karena adanya tantangan yang kompleks dan tidak cukupnya improvisasi operasional untuk menghadapi tantangan perubahan yang kompleks tersebut. Oleh karena itu, pemimpin perubahan yang dibentuk dalam Diklat Kepemimpinan Tingkat IV adalah pemimpin yang mampu melakukan adaptasi dan inovasi terhadap perubahan yang terjadi di lingkungan organisasi. Perubahan tersebut dilakukan dalam rangka mempertahankan dan mengembangkan organisasi menuju tingkat kinerja yang tinggi sesuai dengan harapan dan visinya.

\section{Evaluasi Perilaku}

Evaluasi perilaku mengukur penggunaan atau penerapan pengetahuan, sikap, dan keterampilan dalam bekerja berdasarkan apa yang diperoleh selama diklat. Hasil kuesioner menunjukkan bahwa 91,67\% peserta menganggap pengetahuan yang diberikan selama diklat kurang bersifat praktis. Ketika hal itu ditanyakan secara langsung, sebagian besar peserta menganggap bahwa mata diklat tersebut semuanya penting dan sangat membantu pelaksanaan tugas di kantor. Setelah dikaji lebih lanjut dengan mengamati tempat tugas dan tugas pokok dari beberapa peserta bahwa wajar ada perbedaan tersebut karena adanya perbedaan persepsi. Beberapa peserta yang bekerja pada instansi teknis menganggap bahwa selama diklat akan mendapatkan pengetahuan teknis sesuai bidang pekerjaannya.

Perubahan perilaku dimaksudkan sebagai akibat dan konsekuensi dari keikutsertaan peserta dalam Diklat Kepemimpinan Tingkat IV sekaligus sebagai bentuk keberhasilan dalam mengikuti 
Kepemimpinan Tingkat IV berasal dari akademisi Perguruan Tinggi Negeri di Mataram dan praktisi dari perusahaan. reaksi peserta diklat terhadap pembelajaran ceramah oleh narasumber berada pada kategori memadai dengan skor 75,17. Penilaian reaksi peserta diberikan terhadap 6 aspek kinerja narasumber meliputi: keahlian, penguasaan materi, sistematika penyajian, penggunaan bahasa, dan gaya komunikasi.

Jumlah coach pada Diklat Kepemimpinan Tingkat IV Provinsi NTB Tahun 2014 sebanyak 5 orang yang terbagi dalam 2 angkatan. Setiap angkatan dibimbing oleh 3 orang coach yang masing-masing membimbing 10 orang peserta. kemampuan coach menurut peserta berada pada kategori sangat memadai atau dengan skor $82,93 \%$. Indikator penilaiannya meliputi pemahaman perannya, cara membimbing, pemberian saran, motivasi, dan komunikasi yang dibangun dengan peserta.

Mentor adalah atasan langsung peserta Diklat. Atasan langsung berupa pejabat eselon III dan secara struktural langsung berada di atas peserta pada instansinya yaitu sedang menduduki jabatan Kepala Bidang, Kepala Bagian, Sekretaris, atau Kepala UPT. Jumlah mentor pada Diklat Kepemimpinan Tingkat IV Provinsi NTB Tahun 2014 sebanyak 58 orang. Jumlah tersebut lebih sedikit dari jumlah. reaksi peserta terhadap kemampuan mentor dalam pelaksanaan perannya berada pada kategori sangat memadai.

Penyelenggara diklat memiliki kemampuan dalam mengelola dan menyelenggarakan diklat. tenaga penyelenggara yang sudah mengikuti $T o F$ diklat kepemimpinan pola baru hanya Kabid Diklat Penjenjangan sendiri dan 2 orang Kasubidnya. Sementara staf belum pernah mengikuti ToF . Kondisi tersebut memberikan kesulitan terutama dalam sistem pengelolaan tahapan kegiatan diklat baik dari sisi administrasi maupun operasionalnya. reaksi peserta sebesar 70,62\%. Keberhasilan institusi Diklat dalam mengemban misinya sangat ditentukan oleh mutu keinterelasian unsur-unsur sistemik yang memberikan kontribusi terhadap peningkatan kualitas transformasi dan mutu hasil kerjanya (Danim, 2008: 275).

Secara umum, reaksi peserta terhadap aspek tenaga kediklatan yang mencakup kemampuan widyaiswara, narasumber, coach, mentor, dan kapasitas penyelenggara berada pada kategori memadai yaitu dengan skor rata-rata sebesar 79,03\%. Selengkapnya, reaksi peserta terhadap kemampuan tenaga kediklatan seperti dilihat pada gambar di bawah ini.

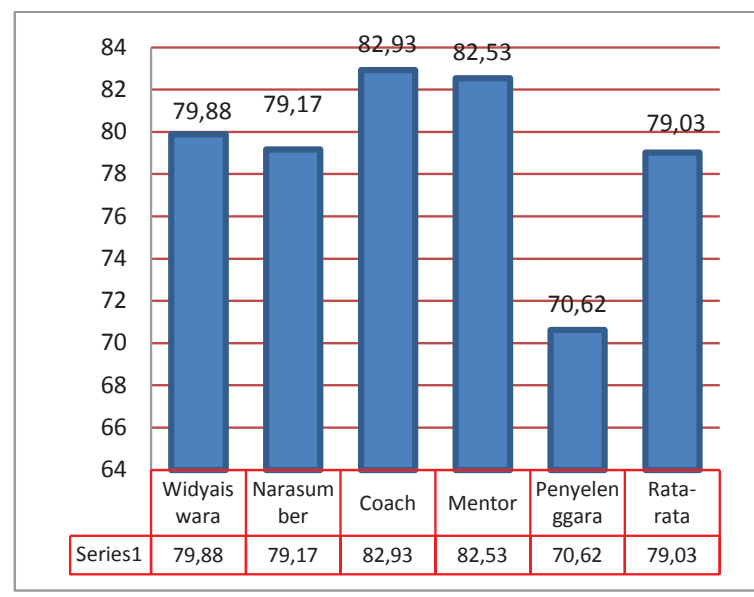

Gambar 2. Reaksi Peserta terhadap Aspek Tenaga Kediklatan

Fasilitas diklat merupakan alat bantu dan penunjang yang digunakan untuk menjamin efektivitas agenda pembelajaran. Fasilitas diklat meliputi sarana dan prasarana kediklatan sesuai standar persyaratan setiap jenis, jenjang, dan program diklat serta jumlah peserta. Komponen fasilitas (sarana dan prasarana) diklat dianalisis berdasarkan ketersediaan serta kelayakan sarana dan prasarana dalam mendukung proses Diklat Kepemimpinan Tingkat IV di BKD dan Diklat Provinsi NTB. Ketersediaan sarana dan prasarana merupakan bagian yang tidak dapat dipisahkan dari proses Diklat terutama untuk menunjang tercapainya tujuan yang diinginkan.

Ruang kelas merupakan tempat belajar yang memungkinkan peserta diklat bergerak leluasa dan tidak berdesak-desakan serta saling mengganggu saat melakukan pembelajaran. Besarnya ruang kelas tergantung pada jenis dan jumlah peserta yang mengikuti diklat. Different kinds of learnings require different environments (Laird, 2003: 195). Jenis pembelajaran yang lebih mengarah kepada skill memerlukan lingkungan belajar yang mendukung percepatan pencapaian skill yang diinginkan. 
terhadap isu dan ide baru serta memungkinkan peserta untuk berlatih dan mengasah keterampilan dan prosedur baru. Pendekatan utama dalam pembelajaran eksperensial adalah permainan peran, game dan simulasi, observasi, pencitraan mental, tugas menulis, dan proyek pembelajaran tindakan. Reaksi peserta terhadap metode pembelajaran

Media yang sudah disiapkan oleh penyelenggara pada pembelajaran adalah berupa $L C D$, papan tulis, dan flip chart. Tenaga pengajar lebih banyak hanya membuat bahan tayang (slide) yang dapat dilengkapi dengan gambar-gambar, musik, atau film yang digunakan dan ditampilkan melalui laptop dalam pembelajaran. Pemanfaatan media dalam penelitian ini meliputi aspek pemilihan dan pemanfaatan media pembelajaran.

Benchmarking dilaksanakan selama lima hari, yaitu angkatan II dilaksanakan tanggal 9 sampai 12 September 2014, dan angkatan III pada tanggal 8 sampai 13 September 2014. Daerah yang dijadikan lokus benchmarking Angkatan II adalah Provinsi Kalimantan Selatan, sedangkan Angkatan II ke Kota Makasar Provinsi Sulawesi Selatan. Instansi yang dikunjungi di Provinsi Kalimatan Selatan adalah Bappeda dan Badan Perijinan Terpadu yang dinilai bagus sehingga perlu dijadikan pembanding. Angkatan III menjadikan Badan Layanan Umum Terpadu dan Dinas Perhubungan dan Kominfo Kota Makasar yang dijadikan tujuan kunjungan. reaksi atau penilaian kepuasan peserta diklat terhadap kegiatan benchmarking ke best practice berada pada kategori memadai dengan skor $69,20 \%$.

Laboratorium kepemimpinan dilaksanakan selama 60 hari kerja (12 minggu). Kegiatan yang dilaksanakan peserta diklat adalah mengimplementasikan rancangan proyek perubahan yang sudah diseminarkan pada seminar rancangan proyek perubahan. Implementasi rancangan proyek perubahan ditekankan pada pelaksanaan tiap tahapan pada roadmap proyek perubahan, kegiatan memobilisasi dukungan stakeholders dan capaian proyek perubahan sesuai tujuan yang sudah direncanakan. Laboratorium kepemimpinan diarahkan kepada bagaimana peserta memimpin perubahan pada unit kerjanya sesuai rancangan yang dibuat sebelumnya. Menciptakan perubahan menurut Flamholtz dan Yvonne R. (2008:49) bahwa pemimpin perubahan adalah orang yang memiliki visi yang besar dan seperangkat karismatik yang menentukan efektivitas kepemimpinan.

Secara umum, penilaian peserta terhadap aspek kurikulum pada komponen jadwal, materi, metode, media, benchmarking, dan laboratorium kepemimpinan dapat dilihat pada gambar di bawah ini.

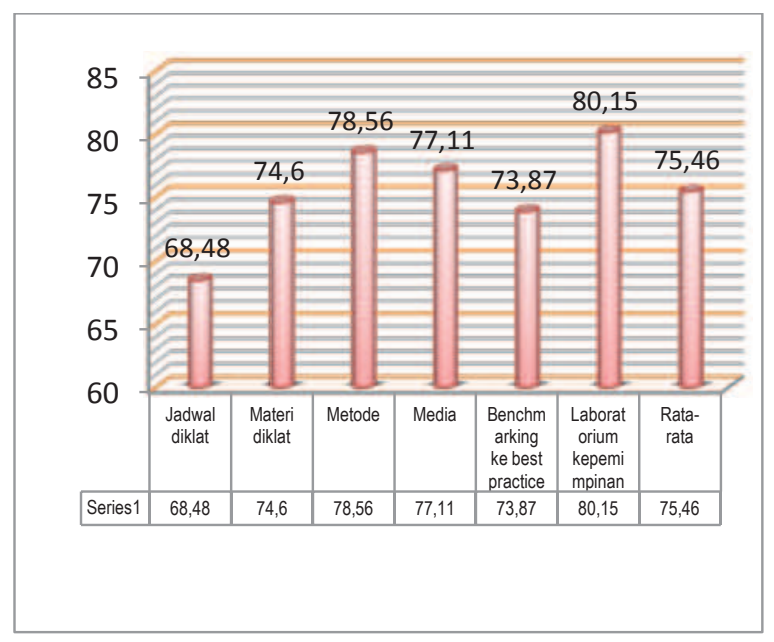

Gambar 1. Reaksi Peserta terhadap Aspek Kurikulum

Widyaiswara yang dilibatkan dalam penyelenggaraan Diklat kepemimpinan Tingkat IV Provinsi NTB sebanyak 10 orang. Widyaiswara tersebut terdiri atas 9 orang laki-laki dan 1 orang perempuan serta 2 orang termasuk dalam jabatan widyaiswara utama dan 8 orang lainnya masih dalam jabatan widyaiswara madya. reaksi peserta diklat terhadap pembelajaran oleh widyaiswara berada pada kategori memadai dengan skor 76,67. Penilaian reaksi peserta diberikan terhadap 11 aspek kinerja widyaiswara, yaitu latar belakang pendidikan, penguasaan materi, sistematika penyajian, pengaitan materi dengan proyek perubahan, pemberian ilustrasi, penggunaan bahasa, komunikasi interaktif, pelibatan peserta, merespon peserta, pembelajaran andragogi, dan pemberian motivasi. Rasio jumlah Widyaiswara selaku tenaga pengajar dengan kebutuhan diklat menunjukkan bahwa jumlah widyaiswara pada BKD dan Diklat Provinsi NTB sebanyak 10 orang. Jika melihat jumlah tenaga widyaiswara dengan kebutuhan diklat (diklat umum, diklat teknis, dan diklat fungsional) yang dilaksanakan dalam satu tahun, maka jumlah widyaiswara dan kebutuhan diklat belum ada kesesuaian.

Narasumber yang digunakan pada Diklat 
terlihat pada tabel di bawah ini.

Tabel 1. Jadwal Tahapan Pelaksanaan Diklat Kepemimpinan Tingkat IV

\begin{tabular}{|c|c|c|}
\hline $\begin{array}{c}\text { Tahapan } \\
\text { Pembelajaran }\end{array}$ & Angkatan II & $\begin{array}{l}\text { Angkatan } \\
\text { III }\end{array}$ \\
\hline $\begin{array}{ll}\text { I. Tahap Diagnosa } \\
\text { Kebutuhan } \\
\text { Perubahan }\end{array}$ & $\begin{array}{l}11 \text { s.d. } 22 \\
\text { Agustus } 2014\end{array}$ & $\begin{array}{l}12 \text { s.d. } 23 \\
\text { Agustus } \\
2014\end{array}$ \\
\hline $\begin{array}{l}\text { II. Tahap Taking } \\
\text { Ownership } \\
\text { (Breakthrough I) }\end{array}$ & $\begin{array}{l}23 \text { s.d. } 28 \\
\text { Agustus } 2014\end{array}$ & $\begin{array}{l}24 \text { s.d. } 29 \\
\text { Agustus } \\
2014\end{array}$ \\
\hline $\begin{array}{l}\text { III. Tahap Merancang } \\
\text { Perubahan dan } \\
\text { Membangun Tim } \\
\text { Efektif }\end{array}$ & $\begin{array}{l}29 \text { Agustus } \\
\text { s.d. } \\
\text { 19 September } \\
2014\end{array}$ & $\begin{array}{l}30 \text { Agustus } \\
\text { s.d. } \\
20 \\
\text { September } \\
2014\end{array}$ \\
\hline 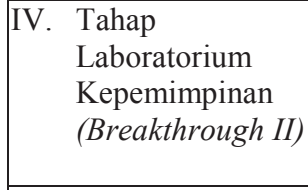 & $\begin{array}{l}20 \text { September } \\
\text { s.d. } 18 \\
\text { November } \\
2014\end{array}$ & $\begin{array}{l}22 \\
\text { September } \\
\text { s.d. } 20 \\
\text { November } \\
2014 \\
\end{array}$ \\
\hline V. Tahap Evaluasi & $\begin{array}{l}19 \text { dan } 20 \\
\text { November } \\
2014\end{array}$ & $\begin{array}{l}21 \text { dan } 22 \\
\text { November } \\
2014\end{array}$ \\
\hline
\end{tabular}

Materi diklat pada Diklat Kepemimpinan Tingkat IV Pemerintah Provinsi NTB diserahkan pengembangannya kepada tenaga pengajar khususnya widyaiswara. Lembaga Administrasi Negara tidak menyiapkan bahan diklat. Pengembangan materi diklat harus sesuai dengan tujuan diklat. Pengembangan materi mengarah kepada pencapaian tujuan diklat, tujuan kurikuler, dan tujuan institusional. Tujuan institusional mengarah kepada harapan dan kebutuhan lembaga terhadap kompetensi yang ingin dicapai. Sitepu (2012: 20) menjelaskan bahwa kehadiran buku baik dalam bentuk cetakan maupun dalam bentuk elektronik telah memberikan pengaruh besar dalam proses belajar dan membelajarkan. Hal tersebut juga disampaikan oleh Atwi Suparman (2012: 283) bahwa kegiatan instruksional ada tiga macam sehingga melahirkan tiga bentuk bahan instruksional. Pertama, mengajar sebagai fasilitator dan peserta didik belajar mandiri dengan menggunkan bahan instruksional mandiri yang didesain secara khusus. Kedua, pengajar sebagai penyaji bahan instruksional yang dipilihnya dengan menggunakan bahan instruksional kompilasi. Ketiga, pengajar sebagai fasilitator dan atau penyaji bahan instruksional dengan menggunakan kombinasi dua bentuk bahan instruksional yaitu bahan instruksional mandiri dan bahan kompilasi. Setiap bentuk kegiatan instruksional di atas membutuhkan bahan instruksional yang berbeda. Untuk kepentingan jurnal dg jumlah halaman yang terbatas (lebih kurang maksimal 10 halaman) perlu diringkas untuk bagian pembahasan, bagian di atas tidak perlu masuk pembahasan. Sebaiknya langsung ke pembahasan inti saja tidak perlu panjang lebar.

Kedalaman dan keluasan materi pembelajaran yang diberikan widyaiswara sangat bergantung kepada pemahaman dan pengalamannya yang berhubungan dengan mata diklat yang diajarkan. Hal ini berarti bahwa cakupan materi sangat bergantung kepada siapa yang memberikan materi tersebut. Widyaiswaralah yang memiliki peran dalam memperkaya materi diklat dengan teori-teori terbatu atau pengkayaan materi dengan pengalaman kerja atau dengan memberikan ilustrasi dari contoh real di birokrasi pemerintahan. Haris Mujiman (2011: 5960) menjelaskan bahwa program pelatihan PNS di Indonesia lebih bersifat spesifik. Kebutuhan diklat ditetapkansetelahdilakukananalisisterhadapdeskripsi tugas tiap jenjang jabatan. Hasil analisis mengarah pada identifikasi kebutuhan pengetahuan, sikap, dan keterampilan yang diperlukan untuk menjalankan pekerjaan pada jenjang tersebut. Kebutuhan itulah yang dijadikan acuan penentuan bahan diklat. Semua peserta diasumsikan membutuhkan materi-materi tersebut walaupun karakteristik peserta berasal dari latar belakang pengalaman kerja serta kemampuan yang berbeda. Asumsi lainnya adalah peserta diklat memiliki kemampuan yang sama dalam menyerap materi pelajaran.

Metode pembelajaran yang digunakan selama pembelajaran di dalam kelas oleh widyaiswara dikatakan oleh peserta diklat sudah cukup bagus. Widyaiswara memiliki keterampilan dalam mengelola kelas dalam pembelajaran. Metode pembelajaran yang sering digunakan oleh widyaiswara adalah metode diskusi, Tanya jawab, ceramah, pemutaran film pendek, dan disertai game-game ringan untuk mempertahankan konsentrasi peserta. Metode pembelajaran yang disarankan dalam pembelajaran diklat adalah berbasis pengalaman (experiential learning). Auerbach (2013: 143) pendekatan pembelajaran eksperiensial (pembelajaran bersumber pengalaman) sangat cocok untuk pelatihan efektif dan behavioral. Metode tersebut membantu para peserta menyadari perasaan dan reaksi mereka 
dan coach. Studi dokumentasi ini dimaksudkan untuk melihat dan menganalisis data tertulis yang digunakan dalam penyelenggaraan diklat. Dokumen yang diteliti berupa berbagai macam baik dokumen primer maupun dokumen sekunder. Kuesioner diberikan kepada peserta diklat untuk mengukur tingkat kepuasan terhadap proses pelaksanaan diklat yang diikuti menyangkut aspek kurikulum, tenaga kediklatan, dan fasilitas diklat.

Analisis data dilakukan dengan menggunakan tiga alur kegiatan secara bersamaan dari methode Miles dan Huberman (2009: 20), yaitu reduksi data, penyajian data, penyimpulan dan verifikasi data. Prosedur Analisis data melalui reduksi, display, dan verifikasi data dalam bentuk naratif. Proses pengolahan data hasil penelitian, mulai darimenyusun, mengelompokkan, menelaah dan menafsirkan data dalam pola, serta menghubungkannya dengan fokus evaluasi. Data mentah hasil observasi dan wawancara ditabulasi dalam bentuk tally kemudian dihitung persentase yang dijadikan dasar dalam pemberian keputusan.

Setelah melalui proses pengumpulan dan analisis data, peneliti harus memastikan bahwa hasil temuan dan interpretasi sudah akurat. Validasi temuan dilakukan melalui berbagai strategi member checking dan triangulasi. Cara ini dimaksudkan untuk mengurangi bias yang melekat pada suatu metode dan memudahkan melihat keluasan penjelasan yang dikemukakan. Dalam proses penelitian, peneliti menanyakan kepada satu atau beberapa sumber data atau partisipan yang terlihat untuk mengecek keakuratan data yang telah dianalisis. Cara ini untuk memberikan keobjektifan dan kebenaran data sehingga informasi yang diperoleh dan disimpulkan dapat dipertanggungjawabkan. Member checking dilakukan secara tertulis melalui terhadap kuesioner, wawancara atau teknik dokumentasi.

\section{HASIL PENELITIAN DAN PEMBAHASAN}

Diklat Kepemimpinan Tingkat IV Pemerintah Provinsi NTB Tahun 2014 dilaksanakan dalam dua angkatan, yaitu angkatan II dan III. Peserta diklat merupakan PNS yang sedang menduduki Jabatan Eselon IV lingkup Pemerintah Provinsi NTB. Peserta diklat angkatan II sebanyak 30 orang terdiri atas 20 orang laki-laki atau sebesar $66,67 \%$ dan 10 orang perempuan atau sebesar 33,33\%. Angkatan III diikuti oleh 30 orang peserta terdiri atas 19 orang laki-laki atau sebesar $63,33 \%$ dan 11 orang perempuan atau sebesar $36,67 \%$. Pangkat dan jabatan peserta diklat bervariasi mulai dari golongan III/b sampai kepada golongan IV/a. Peserta dengan pangkat dan golongan Penata Muda Tingkat I (III/b) sebanyak 1 orang atau sebesar $1,67 \%$; Penata (III/c) sebanyak 21 orang atau sebesar 35\%; Penata Tingkat I (III/d) sebanyak 34 orang atau sebesar 56,67\%; dan Pembina (IV/a) sebanyak 4 orang atau sebesar 6,66\%. Pengalaman kerja Peserta Diklat Kepemimpinan Tingkat IV bervariasi mulai dari 10 tahun atau kurang sampai 26 tahun. Masa kerja 10 tahun atau kurang sebanyak 3 orang atau sebesar 5\%; masa kerja antara $11-14$ tahun sebanyak 20 orang atau sebesar $33,33 \%$; masa kerja antara 15 - 18 tahun sebanyak 14 orang atau sebesar $23,33 \%$; masa kerja antara 19 - 22 tahun sebanyak 16 orang atau sebesar $26,67 \%$; dan masa kerja antara $23-26$ tahun sebanyak 7 orang atau sebesar 11,67\%. Tingkat pendidikan peserta dikelompokkan sebagai berikut: (1) tingkat pendidikan SMA sebanyak 3 orang atau sebesar 5\%; (2) Diploma III sebanyak 2 orang atau sebesar 3,33\%; (3) S1/DIV sebanyak 46 orang atau sebesar 76,67\%; dan (4) tingkat pendidikan S2 sebanyak 9 orang atau sebesar $15 \%$.

Diklat Kepemimpinan Tingkat IV Pemerintah Provinsi NTB diselenggarakan oleh BKD dan Diklat Provinsi NTB. Lembaga tersebut merupakan salah satu lembaga diklat terakreditasi yang diberikan kewenangan untuk menyelenggarakan diklat prajabatan, diklat kepemimpinan, diklat teknis, dan diklat fungsional umum pada lingkup Pemerintah Provinsi NTB.

\section{Evaluasi Reaksi}

Diklat Kepemimpinan Tingkat IV Provinsi NTB dilaksanakan selama 97 hari kerja yang terbagi dalam 282 Jam Pelajaran (JP) atau 32 hari kerja untuk pembelajaran klasikal, dan $585 \mathrm{JP}$ atau 65 hari kerja untuk pembelajaran non klasikal yang diistilahkan dengan breakthrough. Pembelajaran breakthrough tersebut dilaksanakan sebanyak dua tahapan, yaitu tahap taking ownership selama 5 hari dan tahap laboratorium kepemimpinan selama 60 hari. Selama pembelajaran klasikal peserta diasramakan dan diberikan kegiatan penunjang kesehatan jasmani/mental sebanyak 14 JP. Jadwal pelaksanaan Diklat Kepemimpinan Tingkat IV Angkatan II dan III Pemerintah Provinsi NTB sesuai tahapan pembelajaran diklat kepemimpinan seperti 
pelaksanaan praktik kepemimpinan. Aspek tenaga kediklatan mencakup widyaiswara, narasumber, penyelenggara, coach, dan mentor. Aspek fasilitas diklatmeliputi ruang kelas, asrama, sarana pendukung, dan konsumsi. Evaluasi Tingkat kepuasan peserta sangat bergantung kepada kualitas produk atau jasa yang didapatkannya. Montgomery dalam Supranto (2011: 2) membedakan mutu atau kualitas menjadi dua, yaitu mutu desain dan mutu kecocokan (quality of design and quality of conformance).

Evaluasi pembelajaran dalam diklat mencakup: knowledge, skills, and attitudes (Blanchard dan James, W.T. (2007: 348). Mc Alpine dalam Gagne (2005: 265) menjelaskan bahwa pembelajaran merupakan refleksi dari authentic assessement dalam berbagai cara, meliputi: (1) produk seperti buku, permainan, peta, dan pameran; (2) proses kognitif seperti berpikir level tinggi meliputi analisis, sintesis, evaluasi, dan kreativitas sebaik perolehan, pengorganisasian, dan penggunaan informasi; (3) kinerja seperti pelaksanaan eksperimen dan penelitian, presentasi temuan, pertunjukan permainan; dan (4) sikap dan keterampilan sosial seperti sains berbeda budaya dan wawancara individu dan kelompok. Sudjana (2009: 22) menjelaskan bahwa hasil belajar sebagai kemampuan-kemampuan yang dimiliki peserta diklat setelah menerima pengalaman belajarnya.

Evaluasi perilaku difokuskan pada perilaku kerja (pengetahuan, keterampilan, serta sikap dan perilaku) peserta diklat setelah kembali ke dalam lingkungan kerjanya. Perilaku yang dimaksud berupa perilaku kerja yang ada hubungannya langsung dengan materi diklat, dan bukan perilaku dalam konteks hubungan personal dengan rekanrekan kerjanya. Perubahan yang ingin diketahui dalam evaluasi ini adalah seberapa jauh perubahan sikap mental (attitude), perbaikan pengetahuan, dan atau penambahan ketrampilan peserta membawa pengaruh langsung terhadap kinerja peserta ketika kembali ke lingkungan kerjanya. Apakah perubahan tersebut diimplementasikan dalam lingkungan kerja peserta ataukah dibiarkan berkarat dalam diri peserta tanpa pernah diimplementasikan.

Evaluasi hasil difokuskan pada hasil akhir (final result) yang terjadi karena peserta telah mengikuti suatu program (Widoyoko, 2012: 178). Evaluasi level result atau hasil dilakukan untuk mengukur kontribusi program secara keseluruhan terhadap kinerja perusahaan (Pribadi, 2014: 165). Evaluasi level hasil merupakan produk akhir berupa dampak diklat terhadap tingkat produktivitas organisasi yang dapat ditingkatkan setelah alumni dapat menerapkan pengetahuan dan keterampilan yang didapat selama diklat. Perubahan perilaku kerja diharapkan memberikan dampak positif terhadap tempat kerja terutama berhubungan dengan pelayanan publik.

\section{METODE PENELITIAN}

Penelitian ini menggunakan metode penelitian evaluasi dengan pendekatan kualitatif. Evaluasi kualitatif digunakan untuk mengevaluasi karakter, petunjuk, dan efisiensi staf berdasarkan latar belakang dan pengetahuan kegiatan yang relevan (Jacobs \& Christine, 2010: 424). Proses evaluasi kebanyakan memerlukan deskripsi rinci tentang berjalannya suatu program. Deskripsi berdasarkan pada observasi dan atau wawancara dengan staf, peserta diklat, dan petugas administrasi program. Proses evaluasi menggambarkan secara tepat dan rinci jalannya program menggunakan metode kualitatif (Patton, 2009: 31). Dilakukan terhadap penyelenggaraan Diklat Kepemimpinan Tingkat IV Pemerintah Provinsi NTB yang dilaksanakan pada BKD dan Diklat Provinsi NTB. Peserta Diklat Kepemimpinan Tingkat IV sebanyak 60 orang yang terbagi dalam dua angkatan. Penelitian dilaksanakan dari bulan Juli 2014 sampai dengan Desember 2014. Metode kualitatif dalam evaluasi ini bersifat deskriptif.

Evaluasi kualitatif deskriptif lebih diarahkan untuk menentukan efektivitas program Diklat Kepemimpinan Tingkat IV Pemerintah Provinsi NTB. Efektivitas program diklat mencerminkan kualitas layanan penyelenggaraan program dengan melihat kepuasan terhadap layanan yang diberikan kepada peserta diklat serta perubahan perilaku dan hasil program bagi peningkatan kinerja organisasi. Evaluasi dilakukan terhadap empat level evaluasi model Kirkpatrick yang terdiri atas reaksi (reaction), pembelajaran (learning), perilaku (behaviour), dan hasil (result).

Pengumpulan data dilakukan melalui wawancara, observasi, studi dokumentasi dan kuesioner. Observasi dilakukan secara langsung ke lokasi penelitian pada saat penyelenggaraan program. Wawancara dilakukan dengan berinteraksi dan berkomunikasi langsung dengan peserta diklat, atasan dan bawahan peserta diklat pada unit kerjanya, penyelenggara diklat, widyaiswara, narasumber 
kurikulum pola baru kepemimpinan perubahan yang mulai diterapkan sejak tanggal 2 Januari 2014.

Kebermaknaan program Diklat Kepemimpinan Tingkat IV akan efektif jika kegiatan tersebut diakhiri dengan evaluasi. Evaluasi dalam aktivitas diklat dapat berupa evaluasi hasil belajar dan evaluasi program. Evaluasi hasil belajar lebih difokuskan untuk menilai hasil belajar yang dicapai oleh peserta setelah mengikuti program diklat. Sedangkan evaluasi program dilakukan untuk menilai efektivitas dan efisiensi program. Evaluasi program bersifat lebih holistik daripada evaluasi hasil belajar.

Semua aspek dan komponen sistem diklat dapat dinilai efektivitas dan efisiensinya melalui evaluasi program. Evaluasi diklat dilaksanakan dengan tiga alasan khusus, yaitu: (1) untuk menentukan efektivitas suatu program diklat dan mendapatkan informasi untuk mengembangkan program diklat pada masa yang akan datang; (2) untuk menentukan apakah program diklat diteruskan, dimodifikasi, atau dihentikan; (3) untuk memberikan bukti nyata mengenai keberadaan lembaga pelatihan dengan menunjukkan kontribusinya terhadap sasaran serta tujuan perusahaan (Kirkpatrick, 2005: 17).

Diklat mencakup tiga aspek pokok yaitu perolehan pengetahuan, keterampilan, dan sikap perilaku dalam upaya meningkatkan kinerja pegawai dalam melaksanakan tugas dan tanggung jawabnya. Struktur kurikulum Diklat Kepemimpinan Tingkat IV disusun menjadi lima tahap pembelajaran: (1) Tahap Diagnosa Kebutuhan Perubahan, tahap penentuan area pengelolaan kegiatan organisasi yang akan mengalami perubahan; (2) Tahap Taking Ownership (Breakthrough I), pembelajaran yang mengarahkan peserta membangun organizational learning atau kesadaran dan pembelajaran bersama akan pentingnya mereformasi area kegiatan organisasi yang bermasalah. Mata diklat pada tahap ini adalah couching and counseling; (3) Tahap Merancang Perubahan dan Membangun Tim, membekali peserta dengan pengetahuan membuat rancangan perubahan yang komprehensif menuju kondisi ideal pengelolaan organisasi yang dicita-citakan; (4) Tahap Laboratorium Kepemimpinan (Breakthrough II), tahap ini mengarahkan peserta untuk menerapkan dan menguji kapasitas kepemimpinannya di tempat kerjanya dan memimpin implementasi perubahan yang telah dibuatnya. Mata diklat pada tahap ini adalah couching and counseling; (5) Tahap
Evaluasi, merupakan tahap berbagi pengetahuan dan pengalaman dalam memimpin implementasi proyek perubahan. Kegiatan tersebut dilakukan dalam bentuk seminar. Mata diklat pada tahap ini adalah Seminar Laboratorium Kepemimpinan dan Evaluasi.

Secara khusus evaluasi program pada lembaga pemerintah dan pendidikan merupakan proses untuk menjamin akuntabilitas dan peningkatan berkelanjutan (Edward, Scott dan Nambury, 2007: 3). Kualitas penyelenggaraan diklat kepemimpinan harus dilihat secara menyeluruh terhadap keseluruhan tahapan mulai dari persiapan, pelaksanaan, sampai kepada hasil penilaian serta dampak diklat terhadap peningkatan produktivitas atau kinerja layanan organisasi.

Evaluasi model Kirkpatrik sangat relevan dengan komponen yang melekat dalam pelaksanaan diklat. Penerapan model Kickpatrick dalam penelitian ini meliputi level reaksi (reaction), pembelajaran (learning), perilaku (behaviour), dan hasil (result). Secara umum penelitian ini bertujuan untuk mengetahui keberhasilan penyelenggaraan program Diklat Kepemimpinan Tingkat IV Pemerintah Provinsi NTB. Secara operasional penelitian evaluasi ini memiliki tujuan: (1) Mengetahui kepuasan peserta terhadap pelaksanaan program Diklat Kepemimpinan Tingkat IV Pemerintah Provinsi NTB (reaction); (2) Mengukur pencapaian pengetahuan, sikap, dan keterampilan peserta setelah mengikuti Diklat Kepemimpinan Tingkat IV Pemerintah Provinsi NTB (learning); (3) Mengetahui penerapan perubahan perilaku peserta Diklat Kepemimpinan Tingkat IV Pemerintah Provinsi NTB (behaviour); dan (4) Mengetahui dampak perubahan perilaku peserta Diklat Kepemimpinan Tingkat IV Pemerintah Provinsi NTB (result).

Evaluasi reaksi merupakan tahap evaluasi yang melihat efektivitas program diklat berdasarkan reaksi atau tanggapan peserta terhadap pelaksanaan program yang diikuti. Evaluasi reaksi ini disebut juga lembar kepuasan pelanggan (customer satisfaction sheet) karena bertujuan mendapatkan masukan dan komentar peserta terhadap program diklat berdasarkan kepuasan peserta terhadap pelayanan dari penyelenggara program menyangkut kurikulum, tenaga kediklatan, dan fasilitas yang mereka terima. Aspek kurikulum meliputi pengaturan jadwal, pengembangan materi, penggunaan metode, pemilihan media, kegiatan benchmarking, dan 
Persoalan kompetensi aparatur memang merupakan determinan penting mengingat dipundak aparatur memiliki tugas ganda, selain dituntut harus mampu memberikan layanan pada masyarakat secara adil dan transfaran, dan juga harus mampu menunjukkan loyalitas, dedikasi dan etoos kerja serta integritas yang tinggi. Tugas ganda tersebut akan dapat terealisasi manakala didukung dengan kompetensi aparatur yang profesional.

Kompetensi bagi aparatur negara menjadi salah satu pertimbangan dalam pengangkatan jabatan dan pengembangan karier. Selain itu, kompetensi menjadi tuntutan dan kewajiban untuk dimilikinya dengan alasan tugas pokok, fungsi, kewenangan dan tanggungjawab yang harus dilaksanakan dalam pelayanan publik, kepemerintahan yang baik, mengimbangi perubahan lingkungan strategis internal dan eksternal, perkembangan ilmu pengetahuan dan teknologi, serta tuntutan pelaksanaan otonomi daerah. Undang-Undang Nomor 5 Tahun 2014 tentang Aparatur Sipil Negara, Pasal 70 ayat 1 mengamanatkan bahwa setiap Pegawai ASN memiliki hak dan kesempatan untuk mengembangkan kompetensi.

Salah satu upaya peningkatan kompetensi aparatur adalah melalui Pendidikan dan Pelatihan (Diklat). Diklat memiliki peran strategis dalam meningkatkan kualitas sumber daya aparatur professional dengan kompetensi, sikap dan perilaku sesuai harapan dan fungsinya dalam jabatan tertentu. Namun demikian, beberapa hasil penelitian dan fakta di lapangan menunjukkan bahwa penyelenggaraan diklat selama ini belum memberikan output dan outcome yang jelas bagi alumni dan organisasinya. Hal ini memperlihatkan bahwa tingkat ketercapaian tujuan kebijakan (the degree of accomplishment) belum optimal. Keikutsertaan seorang pegawai dalam diklat bukan saja tidak memberikan kemanfaatan terhadap karir pegawai, namun juga tidak memberikan kemanfaatan bagi organisasi. Hal tersebut lebih banyak disebabkan oleh belum adanya keterkaitan antara kebijakan kepegawaian dengan kebijakan diklat. Kurikulum, program, dan materi diklat lebih menonjolkan ranah kognitif dan psikomotorik daripada ranah afektif. Kompetensi lulusan belum sebanding dengan investasi yang dikeluarkan dan dinamika tuntutan penyelenggaraan pemerintahan dan pembangunan.

Diklat seharusnya dapat menjadi solusi kesenjangan kompetensi aparatur. Keikutsertaan peserta, cakupan materi dan model delivery-nya serta teknis pelaksanaannya didesain sebagai pencerminan kultur adult education yang sekaligus memadukan pembentukan disiplin, kapasitas akademis dan administratif dalam suasana kolegial. Sistem rekruitmen peserta didasarkan pada kebutuhan organisasi, alasan peningkatan kinerja, kemampuan dan keterampilan pegawai, kepangkatan dan sebagainya (Thoha, 2005:70).

Salah satu bentuk reformasi kediklatan yang tengah dilakukan oleh lembaga pembina diklat aparatur yaitu Lembaga Administrasi Negara (LAN) adalah dengan adanya perubahan pola penyelenggaraan diklat aparatur. Penyelenggaraan diklat pola baru untuk Diklat Prajabatan dan Diklat Kepemimpinan melalui perubahan kurikulum dan pola pembelajaran yang in class dan off campus serta penekanan pada pembentukan karakter. Hal ini terbukti dengan dikeluarkannya Peraturan Kepala LAN (Perkalan) Nomor 10, 11, 12, dan 13 Tahun 2013 tentang Pedoman Penyelenggaraan Diklat Kepemimpinan ingkat I, II, III, dan IV serta Perkalan Nomor 38 dan 39 Tahun 2014 tentang Pedoman Penyelenggaraan Diklat Prajabatan CPNS Golongan I-II dan III.

Sejak tahun 2014, penyelenggaraan Diklat Kepemimpinan mengalami perubahan pola penyelenggaraan untuk lebih meningkatkan kualitas, efisiensi, dan efektivitas diklat. Perubahan pola tersebut dilaksanakan dengan alasan bahwa kurikulum diklat pola sebelumnya dirasakan masih lemah dilihat dari sisi jumlah dan substansi mata diklat kurang menyentuh aspek kepemimpinan terutama pada sisi praktik. Selain itu, metode pembelajaran klasikal diubah dengan berbasis pengalaman (experiential learning) dan praktik kepemimpinan serta penekanan lebih besar pada aspek pembentukan karakter dan integritas peserta.

Penyelenggaraan Diklat Kepemimpinan Tingkat IV di Provinisi NTB selama ini mengacu kepada Peraturan Kepala LAN RI Nomor 541/ XIII/10/6/2001 tentang Pedoman Penyelenggaraan Diklat Kepemimpinan Tingkat IV tanggal 10 Agustus 2001. Selanjutnya, berdasarkan Peraturan Kepala LAN RI Nomor 13 Tahun 2013 tentang Pedoman Penyelenggaraan Diklat Kepemimpinan Tingkat IV tanggal 24 September 2013, maka penyelenggaraan Diklat Kepemimpinan Tingkat IV harus mengikuti 


\title{
Evaluasi Program Pendidikan dan Pelatihan Kepemimpinan Tingkat IV Pemerintah Provinsi Nusa Tenggara Barat
}

\begin{abstract}
Muslihin*
Abstract: The purpose of this research is to explain the program implementation quality and efectivity of the leadership training and education of forth level of the Government of West Nusa Tenggara Province. This research includes evaluation research program with Kirkpatrick's model (reaction, learning, behaviour, result) by using descriptive qualitative approach. Data collection instruments used were interview, observation guidelines, the study documents, and questionnaires. Data analysis using models Miles and Huberman through the display of data, data reduction, and data verification. The results showed that the participants' reactions to learning by training trainers in the category adequate with a score of $76.67 \%$, reaction training participants towards learning lectures by speakers that are in adequate category with a score of $75.17 \%$, according to the coach's ability participants with a score of $82.93 \%$, both in terms of system management and operational administration by $70.62 \%$. Participants' reactions to the energy aspects of training and education that is equal to $79.03 \%$. The effectiveness of the program in terms of the reaction of participants was on the score of 65.52 or the adequate category and questionnaire results $91.67 \%$ of participants consider the information given during the training is less practical nature.
\end{abstract}

Keywords: Program evaluation, Kirkpatrick model, leadership, training and education

\begin{abstract}
Abstrak: Tujuan penelitian ini adalah untuk menjelaskan kualitas dan efektivitas penyelenggaraan Diklat Kepemimpinan Tingkat IV pada Pemerintah Provinsi NTB. Penelitian ini termasuk jenis penelitian evaluasi program dengan model Kirkpatrick (reaction, learning, beaviour, result) dengan menggunakan pendekatan kualitatif deskriptif. Instrumen pengumpulan data yang digunakan adalah pedoman wawancara, pedoman observasi, studi dokumen, dan kuesioner. Analisis data mengunakan model Miles dan Huberman melalui display data, reduksi data, dan verifikasi data. Hasil penelitian menunjukkan bahwa reaksi peserta diklat terhadap pembelajaran oleh widyaiswara berada pada kategori memadai dengan skor 76,67 \%, reaksi peserta diklat terhadap pembelajaran ceramah oleh narasumber berada pada kategori memadai dengan skor 75,17\%, kemampuan coach menurut peserta dengan skor 82,93\%, sistem pengelolaan baik dari segi administrasi dan operasional sebesar 70,62\%. Reaksi peserta terhadap aspek tenaga kediklatan yaitu sebesar 79,03\%. Efektivitas program dari segi reaksi peserta adalah pada skor 65,52 atau pada kategori memadai dan hasil kuesioner $91,67 \%$ peserta menganggap pengetahuan yang diberikan selama diklat kurang bersifat praktis.
\end{abstract}

Kata kunci: Evaluasi program, model kirkpatrik, kepemimpinan, pendidikan dan pelatihan

\section{PENDAHULUAN}

Sumber daya aparatur mempunyai peran penting dalam mengembangkan tatanan pemerintahan. Pergeseran paradigma penyelenggaraan pemerintahan dari "rule government" menjadi "good governance" dan dari sentralistik ke desentralistik, perlu disikapi dan diimbangi dengan sumber daya aparatur yang memiliki kompetensi yang memadai dan sesuai tuntutan nasional dan tantangan global.

* Ismail, IAIN Mataram, Jl. Lestrai Gg. Manalagi XI No.6 Pejeruk, Ampenan Lombok, NTB. Telepon:08123706275/087865555560,email: ismail_thoib@yahoo.com 
dari uji coba 2 ke uji coba 3 adalah 0.89 untuk uji coba lapangan dan 0.73 untuk uji coba kelompok kecil. Berdasarkan realitas hasil nilai mahasiswa dala uji coba tersebut dapat disimpulkan bahwa produk ini memiliki kelayakan empiris karena memudahkan mahasiswa dalam mencapai tujuan instruksional khusus.

Dari segi efektivitas, pembelajaran filsafat pendidikan Islam dengan menggunakan paket yang dikembangkan terbukti jauh lebih efektif dibandingkan dengan pembelajaran dengan tidak menggunakan paket.Efektivitas pembelajaran dengan menggunakan paket jauh lebih tinggi dari pembelajaran konvensional. Rata-rata efektivitas pembelajaran konvensional 36,66 \%, sedangkan pembelajaran dengan menggunakan paket 87,2\%. Tingkat partisipasi kritis mahasiswa dengan pembelajaran konvensional adalah 37,5\%, sedangkan dengan menggunakan paket 92,5\%. Motivasi belajar mahasiswa dengan metode pembelajaran konvensional 45\%, sedangkan metode pembelajaran dengan menggunakan paket 75,8\%. Ketercapaian hasil belajar sesuai yang diinginkan 27,5\% pada pembelajaran dengan metode konvensional dan $87,2 \%$ dengan menggunakan paket pembelajaran yang dikembangkan.

\section{DAFTAR PUSTAKA}

Achmadi, Asmoro. Filsafat Umum (Edisi Revisi). Jakarta: RadjaGrafindo Persada, 2013.

Arsyad,Azhar,Media Pembelajaran.Jakarta: Radja Grafindo Persada, 2011.

Asyhar, Rayandra, Kreatif Mengembangkan Media Pembelajaran. Jakarta: Referensi Jakarta, 2012

Aunurrahman, Belajar dan Pembelajaran.Bandung: Alfabeta, 2009.

Anonim, Thinking Critically. Booklet Accompanies the Skill for Open Univercity Study, www. open.ac.uk/skills for Studi, 2008.

Duren, Robert, dkk., Critical Thinking Framework For Any Dicipline, http/www.isetl org/ijtlhhe: International Journal of Teaching and Learning in Higher Education, Volume 17, number 2, 2006.

Dick, Walter. Lou Carey dan James Carey, The
Systemic Design of Instruction. Boston: Pearson, 2009.

Event, Marie, An Verburght \& Jan Elen., Critical Thinking in College Freshmen: The Impact of Secondary and Higher Education. www. sciedu.ca/ijhe. International Journal of Higher Education, Vol.2,N0.3, 2013.

Gredler. Margaret E., Learning and Instruction, Theory Into Practice. Columbia Ohio: Perason, 2009.

Thoib, Ismail.Filsafat Pendidikan Islam, Membangun Insan Muslim Berkarakter. Mataram: Lembaga Pengkajian-Publikasi Islam \& Masyarakat (LEPPIM) IAIN Mataram, 2013.

Jamaris, Martini, Orientasi Baru dalam Psikologi Pendidikan. Jakarta: Yayasan Penamas Murni, 2010.

Nawawi, Ismail, Managemen Pengetahuan (Knowledge Management), Teori dan Aplikasi Dalam Mewujudkan Daya Saing Organisasi Bisnis dan Publik, Bogor: Ghalia Indonesia, 2012.

Oliva, Peter F. Developing The Curriculum. Boston: Pearson, 2004.

Pecorino, Philip A.Critical Thinking and Philosophy. Queensborough Community College, Cuny: Spring \& Fall, 1987.

Rusman, Model-Model Pembelajaran, Mengembangkan Profesionalisme Guru. Jakarta: Raja Grafindo Persada, 2013.

Rusman, Deni Kurniawan, Cepi Riyana, Pembelajaran Berbasis Teknologi Informasi dan Komunikasi. Depok: Radja Grafindo Persada, 2012.

Sutrisno, Kreatif Mengembangkan Aktivitas Pembelajaran Berbasis TIK.Jakarta: Referensi, 2012. Tilaar, H.A.R., Multikulturalisme TantanganTantangan Global Masa Depan Dalam Transformasi Pendidikan Nasiona.Jakarta: Grafindo PT Gramedia, 2004.

Zafri, Berpikir Kritis Pembelajaran Sejarah. FIS UNP: Jurnal Diakronika, 2012.

Zuchdi, Darmiyati, Humanisasi Pendidikan, Menemukan Kembali Pendidikan Yang Manusiawi, Jakarta: Bumi Aksara, 2010. 
tersebut tampak pada kemauannya yang keras untuk selalu berada dalam kondisi "taat" melaksanakan perintah-perintah Tuhan dan taat pula meninggalkan larangan-larangan Tuhan.

Kedua, ranah interaksi horizontal, yang menampakkan diri dalam pola interaksi yang selalu baik kepada sesama manusia. Karakter baik kepada sesama menampakkan diri dalam sikap-sikap universal seperti: jujur, adil, amanah, tenggang rasa, gotong royong, menolong, dll. Selain kepada sesama manusia, ranah interaksi horizontal juga terjadi antara manusia dengan makhluk-makhluk Tuhan yang ada di alam. Kebaikan pada alam tampak pada sikap selalu memelihara dan merawat kelestarian alam dan makhluk-makhluk Tuhan, memanfaatkan segala ciptaan sesuai peruntukkannya secara aktif, kreatif dan produktif, serta tidak suka membuat kerusakan di muka Bumi.

Pembelajaran filsafat pendidikan Islam harus didesain untuk mengantarkan mahasiswa mencapai "alhikmah", yaitu ketaqwaan, kesucian, dan kasih sayang. Ketaqwaan kepada Tuhan (Allah swt) adalah inti dari segala kebajikan.Namun tidak ada ketaqwaan tanpa kesucian.Oleh karena itu, filsafat pendidikan Islam harus mampu mempresentasikan sejumlah tujuan, metode, dan materi pembelajaran yang memungkinkan mahasiswa menjadikan kesucian sebagai tradisi. Kesucian yang dimaksud bukan hanya kesucian fisik, badan, dan pakaian dari najis; akan tetapi juga kesucian ruhaniah dari segala sesuatu yang menjadikannya kotor. Kesucian ruhaniah penting maknanya bagi mahasiswa, karena hanya ruhani yang suci yang dapat memancarkan pikiran, rasa, tutur kata, dan perilaku yang terpuji.

Di samping tuntutan idealitas komponenkomponen pendidikan yang disebutkan di atas, pengembangan model penting dilakukan untuk merubah perilaku berpikir mahasiswa menjadi lebih baik. Saat ini, IAIN Mataram pada umumnya dan Fakultas Ilmu Tarbiyah dan Keguruan pada khususnya sering dihadapkan kepada kondisi yang paradoksal. Di satu sisi, nama besar sebagai institusi Islam menuntut mahasiswa mampu menunjukkan keteladanan kepada masyarakat, tentu saja, dengan menampilkan perilaku-perilaku dan karya-karya akademik yang membanggakan. Akan tetapi, di sisi lain, masyarakat justru sedikit kecewa dengan perilaku yang dipertontonkan oleh mahasiswa. Mahasiswa IAIN Mataram lebih dikenal sebagai mahasiswa yang suka demo dan urak-urakan. Pada saat demontrasi mahasiswa berada dalam kondisi emosional tidak terkontrol, sehingga seringkali mengeluarkan kata-kata kotor dan perilaku anarkis. Kondisi ini tentu saja sangat bertentangan dengan nilai-nilai ajaran yang seharusnya sudah mereka terima di kampus, termasuk ajaran yang mereka peroleh dari mata kuliah Filsafat pendidikan Islam.

\section{KESIMPULAN}

Penelitian dan pengembangan paket pembelajaran filsafat pendidikan Islam berbasis berpikir kritis dilakukan untuk menjawab kebutuhan nyata dosen dan mahasiswa FITK IAIN Mataram dalam rangka peningkatan performance dan hasil belajar dan pembelajaran mata kuliah filsafat pendidikan Islam. Pengembangan paket dilakukan dengan mengacu kepada langkah-langkah pengembangan instruksional Dick and Carey untuk menghasilkan modul pembelajaran, panduan dosen, dan panduan mahasiswa.

Produk yang dihasilkan layak secara teoretik dan layak secara empirik. Secara teoretik, produk memiliki kelayakan dari sisi materi pembelajaran mencapai rata-rata $91 \%$, sedangkan dari sisi desain pembelajaran mencapai rata-rata $91,50 \%$. Secara empirik, produk ini sudah terbukti efektif dalam meningkatkan perolehan hasil belajar pada subjek uji coba; baik uji coba terbatas (small group), maupun uji coba lapangan. pada uji coba terbatas, perolehan nilai rata-rata mahasiswa pada uji coba 2 lebih besar dan berbeda secara siginifikan dengan hasil uji coba 1 (8.18 > 7.42), nilai rata-rata uji coba 3 lebih besar dan berbeda secara signifikan dengan nilai uji coba $2(9.1$ > 8.18). sedangkan pada uji coba lapangan menunjukkan bahwa nilai rata-rata uji coba 2 lebih besar dan berbeda secara signifikan dengan nilai uji coba $1(7.76>6.76)$, nilai rata-rata uji coba 3 lebih besar dan berbeda secara signifikan dengan nilai uji coba $2(8.65>7.76)$. Bila dibandingkan antara nilai rata-rata uji coba terbatas dengan uji coba lapangan, maka dapat diketahui bahwa persentase hasil uji coba lapangan secara rata-rata per komponen lebih meningkat jika dibandingkan dengan hasil uji coba kelompok kecil dengan perbandingan kenaikan hasil dari uji coba 1 ke uji coba 2 pada uji coba lapangan adalah sebesar 1.0 lebih besar dibandingkan hasil uji coba 1 dan 2 pada ujicoba kelompok kecil yang hanya mencapai 0.76 . sedangkan perbandingan kenaikan 
mereka terbiasa fokus. Artinya, kalau pendidikan itu dimaksudkan sebagai instrument untuk mengenal dan mengabdi kepada Tuhan, maka pendidikan harus diselenggarakan berdasarkan nilai-nilai yang terkandung dalam ajaran Tuhan, tidak boleh melanggar perintah dan larangan Tuhan. Begitu pula dengan manusia, kalau pendidikan dipahami sebagai proses pemanusiaan manusia, maka pendidikan tidak boleh menginjak-injak harga diri manusia, proses pendidikan harus proses yang memanusiakan, yaitu proses yang menghargai martabat, derajat, dan potensi-potensi manusia.

Dengan demikian, Filsafat Pendidikan Islam seyogianya membelajarkan sesuatu yang bermakna bagi mahasiswa untuk menjalin komunikasi tiga arah secara simultan dan seimbang. Tiga arah komunikasi dimaksud adalah komunikasi vertikal dengan Tuhan, dan komunikasi horizontal dengan sesama manusia dan dengan makhluk ciptaan Tuhan lainnya di alam semesta. Dengan kata lain, dalam posisinya sebagai MKK, mata kuliah ini seyogianya tidak hanya diarahkan untuk memahami pemikiran para filosof muslim tentang unsur-unsur mikro pendidikan Islam, akan tetapi juga diarahkan untuk menfasilitasi mahasiswa menumbuhkan kemampuan kritis dan kreatif dalam memahami permasalahan (problematika) pendidikan Islam dan kemampuan mengembangkan alternatif pemecahan masalah pendidikan Islam berbasis nilai-nilai qur'ani; baik yang berdimensi ketuhanan (habluminallah) maupun yang berdimensi kemanusiaan (habluminannas), maupun yang berdimensi kemakhlukan (habluminal qoinaat).

Implikasi dari pemikiran tersebut adalah bahwa cakupan silabus filsafat pendidikan Islam tidak boleh terbatas pada telaah mikro paedagogik pendidikan Islam, akan tetapi perlu diperluas sehingga meliputi telaah mendalam tentang hakikat Tuhan, hakikat manusia, dan hakikat alam, yang merupakan telaah makro paedagogik pendidikan Islam. Pemahaman mendalam tentang hakikat Tuhan, manusia, dan alam menjadi kemampuan prasyarat dalam merumuskan konsep-konsep hakikat pendidikan Islam serta melakukan reformulasi pendidikan Islam.

Dengan demikian, cakupan (keluasan dan kedalaman) materi pembelajaran dalam silabus filsafat pendidikan Islam dapat dibagi dalam tiga kategori besar.Pertama, telaah mendalam tentang hakikat Tuhan, manusia, dan alam serta beragam implikasinya bagi pendidikan Islam.Kedua, telaah mendalam tentang hakikat komponen-komponen pendidikan Islam, yang dibangun atas dasar pemahaman utuh dari materi bagian pertama. Ketiga, telaah mendalam terhadap problematika dan kemungkinan reformulasi pendidikan Islam menuju pendidikan Islam yang lebih baik dan lebih bermartabat.Bagian ketiga merupakan bagian yang sangat krusial karena menjadi manifestasi dari pemahaman dan kesadaran yang terbangun secara sistemik dari dua bagian sebelumnya.Dari uraian di atas dapat digambarkan kerangka bangun cakupan tujuan dan materi filsafat pendidikan Islam sebagai berikut:

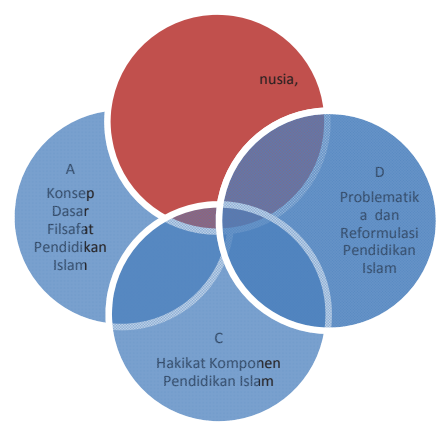

Gambar 9. Cakupan Materi Filsafat Pendidikan Islam

Gambar di atas menunjukkan empat bagian tujuan dan materi filsafat pendidikan Islam saling mengandaikan satu dengan yang lain. Pembelajaran Filsafat Pendidikan Islam adalah membelajarkan mahasiswa agar memiliki kecakapan (kognitif) dan keterampilan (psikomotorik) dalam menelaah aneka problematika pendidikan Islam untuk dijadikan sebagai input dalam mengelola dan mengembangkan pendidikan Islam masa depan yang lebih santun, beradab, dan berdaya saing.

Indikator manusia unggul dalam kajian filsafat pendidikan Islam bukanlah manusia yang memiliki titel dan gelar yang berderet-deret, bukan pula manusia yang berhasil mengumpulkan ilmu, harta, dan tahta yang melebihi manusia-manusia lain. Akan tetapi, manusia unggul semata-mata diukur pada derajat ketundukan dan kepatuhannya kepada Tuhan, yang menampakkan diri secara sempurna dalam dua ranah interaksi.Pertama, ranah interaksi vertikal, manusia unggul adalah manusia yang selalu memiliki hubungan yang sangat baik dengan Tuhan.Hubungan 
pengembangan ini dapat direkomendasikan untuk dijadikan sebagai salah satu alternatif yang dapat dipilih oleh dosen dan mahasiswa IAIN Mataram dalam pembelajaran Filsafat Pendidikan Islam.

\section{PEMBAHASAN}

Teori pembelajaran konvensional tidak bisa dipertahankan, karena tidak menguntungkan mahasiswa, tidak menguntungkan dosen, tidak menguntungkan pengguna produk pendidikan, dan yang lebih parah tidak menghargai potensi-potensi kemanusiaan yang dianugrahkan Tuhan kepada manusia.Terdapat benturan keras antara nilai-nilai yang dianut oleh teori pembelajaran konvensional dengan nilai-nilai yang diajarkan Islam tentang hakikat manusia. Islam mengajarkan bahwa manusia merupakan makhluk Tuhan yang memilikikeunggulan komparatif secara alamiah dibandingkan dengan makhluk Tuhan yang lain. Anugrah keunggulan tersebut sengaja diberikan Tuhan karena kemuliaan tujuan penciptaannya, yaitu supaya manusia mampu menjadi khalifah Allah di Bumi.

Teori-teori belajar yang berada di bawah payung konstruktivisme sangat menghargai dan memberi apresiasi yang tinggi terhadap potensipotensi yang dimiliki manusia. Dalam rangka itu, maka konstruktivisme berpendapat bahwa belajar pada hakikatnya bukanlah aktivitas mentransfer ilmu dari luar diri individu; akan tetapi, individulah yang mengkonstruk, membangun sendiri pengetahuannya.

Kemampuan membangun pengetahuan berbeda dengan kemampuan mengumpulkan atau menghimpun pengetahuan. Membangun pengetahuan adalah pekerjaan yang menuntut adanya keterlibatan aktif seluruh potensi yang dimiliki oleh individu yang sedang belajar untuk merumuskan sendiri pengetahuan sesuai dengan kemampuan dan konteks di mana ia berada. Sedangkan mengumpulkan pengetahuan adalah pekerjaan sederhana yang berkonsentrasi hanya pada mengumpulkan sesuatu yang sudah ada, untuk dimasukkan ke dalam diri.

Islam menghendaki manusia-manusia muslim yang belajar hari ini mampu menciptakan dunia baru di masa depan. Bukan membawa masa lalu kepada masa sekarang, apa lagi ke masa depan. Al-qur'an dengan tegas menyatakan: Wahai orang-orang yang beriman, hendaklah masing-masing jiwa/pribadi di antara kamu mendesain/merancang apa yang akan dilakukan di masa depan. Bila semangat al-Qur'an tersebut dihadirkan dalam pembelajaran Filsafat Pendidikan Islam, maka tujuan pembelajaran Filsafat Pendidikan Islam tidak boleh berhenti hanya pada upaya memahami pemikiran filosofis di bidang Pendidikan Islam, akan tetapi perlu ditingkatkan menjadi mampu merumuskan pemikiran-pemikiran filosofis di bidang Pendidikan Islam.

Kemampuan merumuskan pemikiranpemikiran baru merupakan kemampuan spesifik mahasiswa.Mahasiswa dituntut mampu melahirkan sesuatu yang baru, menawarkan konsep-konsep baru, yang sesuai dengan konteks mereka. Sebaliknya, bukan zamannya lagi mahasiswa menghafal pemikiran-pemikiran orang lain. Karena terlalu banyak menghafal pemikiran orang bisa membuat produktivitas berpikir mahasiswa tumpul.

Dari dimensi tujuan pembelajaran, Tujuan dan cakupan materi pembelajaran Filsafat Pendidikan Islam harus dikembangkan lebih tinggi.Pembelajaran Filsafat Pendidikan Islam harus diarahkan untuk melatih mahasiswa mampu berpikir memecahkan masalah-masalah pendidikan Islam, mulai dari masalah-masalah sederhana dan secara bertahap menuju pemecahan masalah-masalah Pendidikan Islam yang lebih kompleks.

Oleh karena itu, silabus Filsafat Pendidikan Islam pun harus ditambah muatannya; dari yang hanya membahas ruang lingkup Filsafat Pendidikan Islam dan hakikat konsep-konsep pendidikan Islam (telaah mikro paedagogik pendidikan Islam) ditambah pembahasan tentang telaah makro paedagogik pendidikan Islam, yang mencakup telaah tentang hakikat Tuhan, Hakikat Alam dan Hakikat Manusia serta Implikasinya bagi Pendidikan.

Pemahaman akan hakikat 3 unsur tersebut di atas (Tuhan, Manusia, dan Alam) serta implikasinya bagi Pendidikan Islam penting dimiliki mahasiswa paling tidak karena dua alasan. Pertama, Manusia sebagai subjek dan objek pendidikan merupakan makhluk Tuhan dan mereka mendiami alam semesta.Memiliki kesadaran sebagai makhluk Tuhan yang sedang mendiami alam semesta penting bagi mahasiswa agar disiplin dalam aktivitas berpikir, tidak tergoda untuk keluar dari ketentuan-ketentuan Tuhan, dan produk pemikirannya pun menjadi rahmat bagi manusia dan alam semesta.

Kedua, merumuskan implikasi pendidikan dari pemahaman-pemahaman akan hakikat Tuhan, manusia, dan alam, penting bagi mahasiswa agar 
bahwa dengan dilakukannya revisi terhadap produk pengembangan pada setiap tahap uji coba, maka produk tersebut semakin efektif, efisien, dan menarik. Data perbandingan hasil uji coba lapangan dan uji coba kelompok kecil ini menjadi barometer untuk menentukan tingkat kelayakan produk pengembangan sebagai salah satu alternative yang bisa direkomendasikan untuk diterapkan pada pembelajaran Filsafat Pendidikan Islam yang sebenarnya.

\section{EFEKTIVITAS MODEL}

Untuk mengetahui efektivitas model dilaksanakan uji efektivitas melalui evaluasi sumatif. Evaluasi sumatif dilakukan percobaan sederhana dengan membandingkan proses dan hasil belajar mahasiswa pada kelas eksperimen dan kelas kontrol. Tujuan evaluasi sumatif adalah untuk mengukur adanya atau tidak adanya perbedaan proses dan hasil belajar mahasiswa antara kelas eksperimen dengan kelas kontrol. Hasil evaluasi sumatif dijadikan sebagai bahan rekomendasi untuk menetapkan apakah model yang dikembangkan ini lebih baik, sama, atau lebih buruk dari model sebelumnya.

Desain eksperimen yang digunakan adalah pretest-posttest control group terhadap dua kelompok yang dipilih secara random. Kedua kelompok tersebut kemudian diberi pretest untuk mengetahui keadaan awal adakah perbedaan antara kelompok eksperimen dan kelompok kontrol. Eksperimen akan dilanjutkan apabila nilai pretest antara kelompok ekperimen dan kelompok kontrol menunjukkan tidak ada perbedaan secara siginifikan.

Uji efektivitas model dilakukan pada Jurusan Pendidikan Agama Islam (PAI) Fakultas Ilmu Tarbiyah dan Keguruan IAIN Mataram. Uji coba dilakukan pada kelas A dan kelas B. Kelas A sebagai kelompok treatment, dan kelas B sebagai kelompok pembanding. Kriteria efektivitas model yang dikembangkan dilihat pada 3 (tiga) indikator, yaitu: (1) Partisipasi kritis dalam belajar, (2) kecepatan pemahaman terhadap pelajaran, dan (3) hasil belajar. Rentang skor setiap indikator adalah sebagai berikut: Partisipasi kritis dalam belajar: sangat tinggi (4), tinggi (3) agak tinggi (2), rendah (1). Kecepatan pemahaman: sangat cepat (4), cepat (3), agak cepat (2), lambat (1). Hasil belajar: sangat tinggi (4), tinggi (3), agak tinggi (2), rendah (1). Instrumen untuk mengukur efektivitas paket pembelajaran pembelajaran berbasis berpikir kritis ditunjukkan pada tabel 22 berikut. Perbandingan prosentase efektivitas metode pembelajaran konvensional dengan metode pembelajaran yang menggunakan paket dapat digambarkan dalam histograf pada Gambar 10.

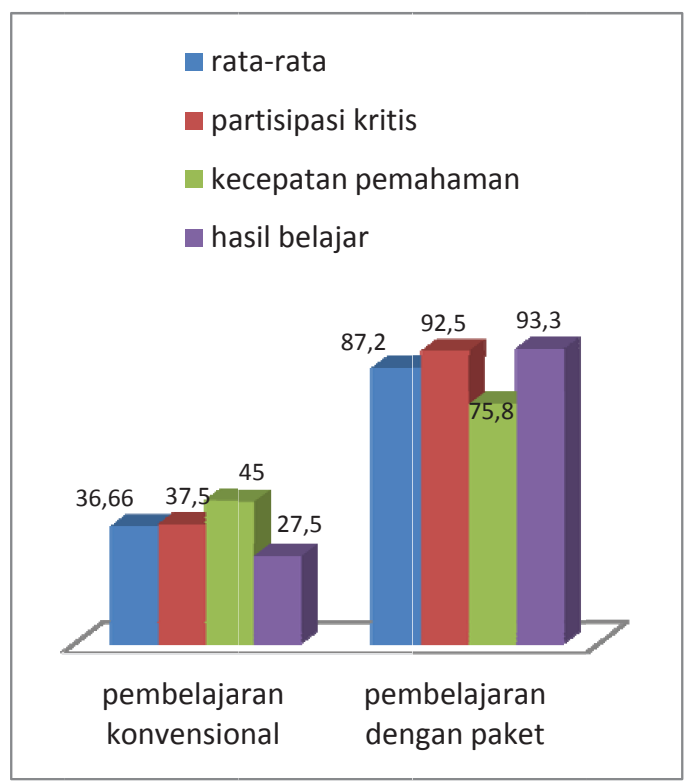

Gambar 10: Histograf Perbandingan Persentase Hasil pembelajaran Konvensional dan Pembelajaran Berbasis BK

Berdasarkan histograf di atas terlihat bahwa efektivitas pembelajaran dengan menggunakan paket jauh lebih tinggi dari pembelajaran konvensional. Rata-rata efektivitas pembelajaran konvensional 36,66 \%, sedangkan pembelajaran dengan menggunakan paket $87,2 \%$. Tingkat partisipasi kritis mahasiswa dengan pembelajaran konvensional adalah 37,5\%, sedangkan dengan menggunakan paket 92,5\%. Kecapatan pemahaman mahasiswa dengan metode pembelajaran konvensional $45 \%$, sedangkan metode pembelajaran dengan menggunakan paket $75,8 \%$. Ketercapaian hasil belajar sesuai yang diinginkan $27,5 \%$ pada pembelajaran dengan metode konvensional dan $87,2 \%$ dengan menggunakan paket pembelajaran. Berdasarkan uji efektivitas di atas dapat disimpulkan bahwa pembelajaran Filsafat Pendidikan Islam dengan menggunakan paket pembelajaran produk pengembangan jauh lebih efektif dibandingkan dengan pembelajaran konvensional, sehingga paket yang diproduksi dalam 
Kekurangan atau kelemahan paket yang perlu disempurnakan menurut mahasiswa adalah pemberian jarak antara sub judul dengan kalimat sesudahnyadan kesalahan pengetikan pada beberapa halaman. Kelemahan atau kekurangan paket yang dinyatakan oleh mahasiswa uji coba perorangan dijadikan sebagai rujukan oleh pengembang dalam menyempurnakan paket pembelajaran. Setelah produk direvisi sesuai masukan pada tahap uji coba perorangan, maka langkah selanjutnya adalah melakukan uji coba pada kelompok kecil mahasiswa.

\section{Uji Coba kelompok kecil}

Dalam uji coba kelompok kecil, mahasiswa belajar dengan menggunakan produk pengembangan Proses belajar dipandu oleh seorang dosen dan seorang observer dan dilaksanakan selama 3 (tiga) kali pertemuan. Pada setiap kali pertemuan diberikan tes untuk menilai pemahaman dan hasil belajar mahasiswa.Hasil belajar mahasiswa pada tiga kali pertemuan dapat digambarkan dalam histograf pada Gambar 7 berikut:

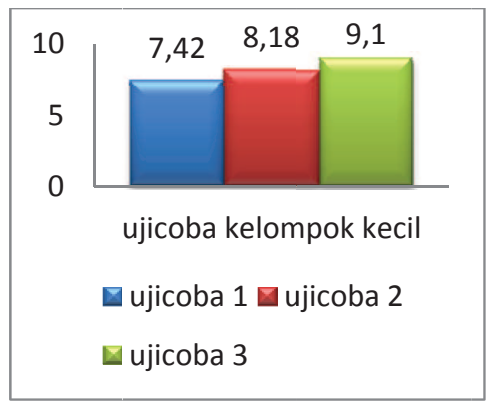

Gambar 7 Kelayakan model dari uji coba kelompok kecil

Berdasarkan histograf tersebut terlihat bahwa nilai rata-rata uji coba 2 lebih besar dan berbeda secara signifikan dengan nilai uji coba $1(8.18>7.42)$, nilai rata-rata uji coba 3 lebih besar dan berbeda secara signifikan dengan nilai uji coba $2(9.1>8.18)$. Kesimpulannya adalah bahwa model pembelajaran dengan menggunakan paket pembelajaran berbasis berpikir kritis terbukti efektif dalam mewujudkan tujuan instruksional khusus.

\section{Uji Coba Kelompok Besar}

Tes hasil belajar pada 35 peserta didik menggunakan paket pembelajaran filsafat pendidikan
Islam berbasis berpikir kritis menunjukkan adanya peningkatan nilai yang siginifikan setelah menggunakan paket produk pengembangan, sebagaimana dideskripsikan dalam histograf Gambar 8.

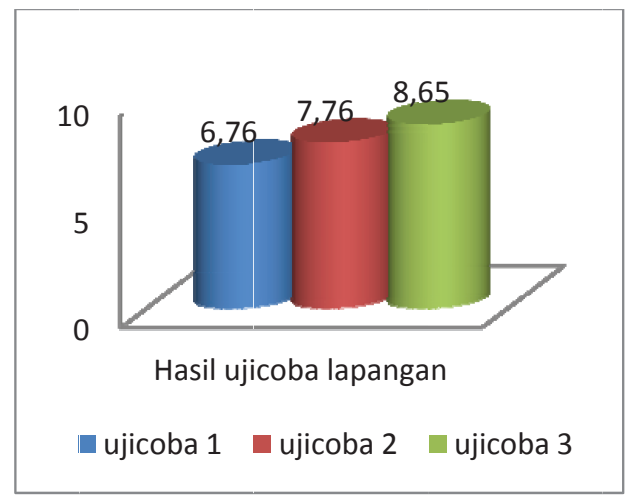

Gambar 8. Hasil Uji Coba Kelompok Besar

Dari data tersebut dapat diketahui bahwa persentase penilaian mahasiswa pada uji coba kelompok besar secara rata-rata per komponen lebih meningkat jika dibandingkan dengan hasil uji coba kelompok kecil dengan perbandingan kenaikan hasil dari uji coba 1 ke uji coba 2 pada uji coba lapangan adalah sebesar 1.0 lebih besar dibandingkan hasil uji coba 1 dan 2 pada ujicoba kelompok kecil yang hanya mencapai 0.76 . sedangkan perbandingan kenaikan dari uji coba 2 ke uji coba 3 adalah 0.89 untuk uji coba lapangan dan 0.73 untuk uji coba kelompok kecil. Perbandingan tersebut tampak jelas dalam histograf pada Gambar 9 berikut:

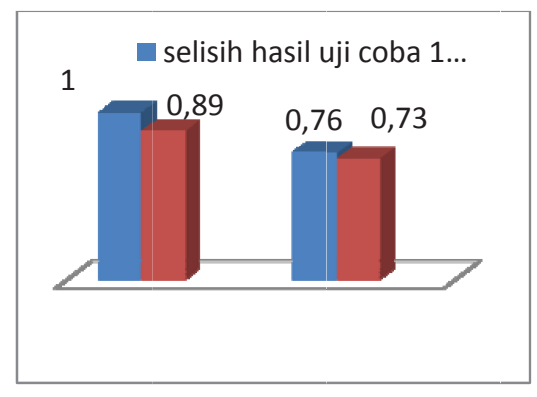

Gambar 9. Perbandingan Uji Coba Kelompok Kecil dan Uji Coba Lapangan

Hasil perbandingan uji coba kelompok kecil dan uji coba lapangan tersebut dapat disimpulkan 
masuk dalam kategori sangat layak dan tidak perlu direvisi adalah petunjuk (100\%), tujuan dan indikator $(95 \%)$, media dan metode (91\%), uraian materi $(90,62 \%)$, rangkuman $(87,5 \%)$, latihan $(87,5)$, tes formatif $(93,75)$, balikan (100\%), dan panduan dosen $(96,59 \%)$. sedangkan yang masuk kategori layak adalah daftar pustaka (75\%). Validasi desain pembelajaran diarahkan untuk memberikan penilaian apakah desain pembelajaran yang tercantum dalam paket pembelajaran yang dikembangkan sudah layak sesuai dengan yang seharusnya atau tidak. Dalam hal ini, validasi ahli desain diarahkan untuk menilai dan memberikan masukan pada aspek-aspek ketepatan, kesesuaian, kemenarikan, dan kemampuan produk dalam memotivasi belajar mahasiswa. Hasil validasi ahli desain menunjukkan bahwa produk yang dikembangkan termasuk dalam kategori sangat layak dengan tingkat kelayakan rata-rata mencapai 91,50 $\%$. Sebaran prosentase hasil uji kelayakan teoretik dari ahli desain dapat digambarkan dalam histograf pada Gambar 5.

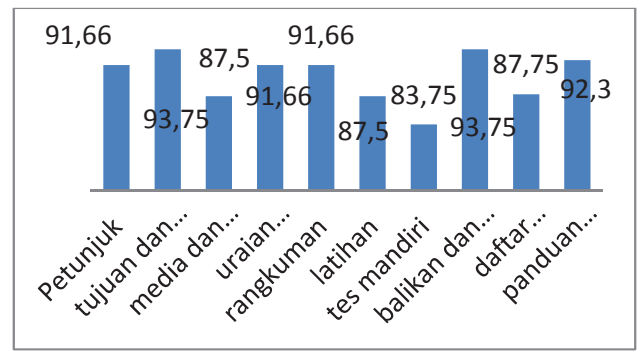

\section{Keterangan:}

$80-100 \%$ : Sangat layak, tidak perlu direvisi

$66-80 \%$ : Layak, tidak perlu direvisi

$56-65 \%$ : Kurang layak, perlu direvisi

$0-55 \%$ : Sangat kurang layak, perlu direvisi

Gambar 5 Kelayakan model menurut ahli desain

Berdasarkan histograf di atas dapat ditegaskan bahwa komponen-komponen paket pembelajaran secara umum sudah layak. Kelayakan tersebut didasarkan pada hasil tinjauan ahli rancangan dan media pembelajaran yang menyatakan bahwa petunjuk sudah $91,66 \%$ jelas dan tepat; Tujuan khusus pembelajaran dan indikator sudah $93,75 \%$ jelas, menarik, dan tepat; media dan metode sudah $87,5 \%$ tepat, sesuai dan menarik; uraian isi/materi pembelajaran sudah 91,66 jelas, tepat, menarik, dan sesuai; d) rangkuman sudah 91,66 \% tepat, sesuai, dan menarik; latihan $87,5 \%$ sesuai dan cukup; tes formatif $93,75 \%$ sesuai dan tepat; balikan $93,75 \%$ jelas; daftar rujukan sudah $87,5 \%$ sesuai.sedangkan buku panduan dosen sudah $92,32 \%$ tepat, jelas, dan menarik.

Objek yang digunakan untuk uji kelayakan empirik adalah mahasiswa dan dosen FITK IAIN Mataram.Proses uji kelayakan empirik dilakukan dalam tiga tahap, yaitu uji satu-satu (one to one), uji kelompok kecil (small group), dan uji lapangan. proses dan hasil uji kelayakan empiris dideskripsikan sebagai berikut.

\section{Uji Coba Perorangan}

Hasil uji coba perorangan menunjukkan komponen-komponen paket pembelajaran secara umum dapat dikatakan telah layak secara empiris. Kelayakan tersebut ditunjukkan oleh penilaian mahasiswa bahwa; a) paket pembelajaran $85 \%$ menarik untuk dibaca, b) urutan isi/materi pembelajaran $85 \%$ jelas bagi mahasiswa, c) istilahisitilah yang digunakan $83 \%$ dapat dipahami oleh mahasiswa, d) isi/materi pembelajaran $90 \%$ mudah untuk dipahami oleh mahasiswa, e) langkah dan metode pembelajaran $90 \%$ meningkatkan motivasi belajar mahasiswa, f) langkah dan metode pembelajaran 90 meningkatkan partisipasi kritis mahasiswa dalam belajar, g) judul tabel dengan urutan isi tabel telah $90 \%$ sesuai, h) tes formatif $83 \%$ mudah untuk dikerjakan oleh mahasiswa, dani) soal tes formatif telah $90 \%$ tepat untuk mengukur tujuan khusus pembelajaran. Hasil uji coba tersebut dapat dideskripsikan dalam histograf pada Gambar 6.

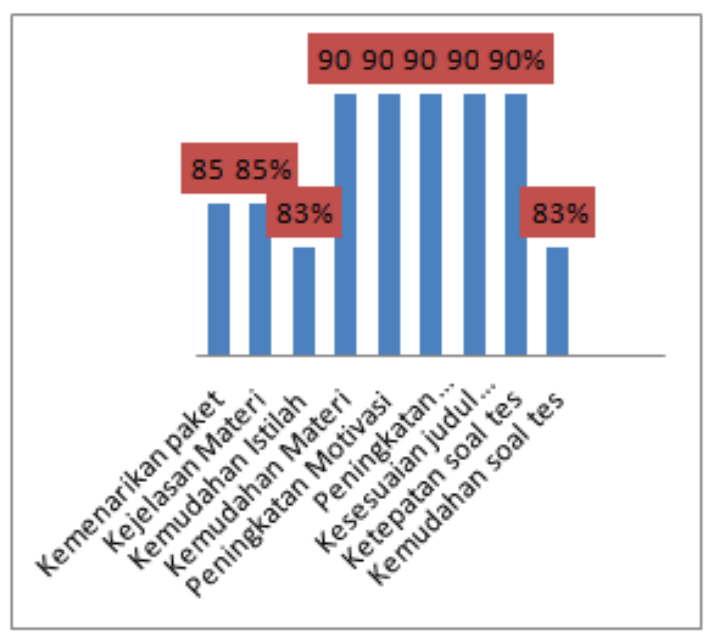

Gambar 6 Kelayakan Model dar Uji Coba Perorangan 
dan mengembangkan materi pembelajaran, (8) merancang dan melaksanakan evaluasi formatif, (9) memperbaiki model pembelajaran berdasarkan hasil evaluasi formatif, dan (10) merancang pelaksanaan evaluasi sumatif. Uji kelayakan teoretik dan empirik produk dilakukan melalui telaah kritis 2 orang ahli materi, 2 orang ahli desain, dan 1 orang ahli bahasa. Sedangkan uji kelayakan empirik dilakukan melalui uji coba perorangan oleh (5 mahasiswa), uji coba kelompok kecil (9 mahasiswa), dan uji coba lapangan (35 mahasiswa). Uji efektivitas produk dilakukan dengan eksperimen sederhana pada 30 orang mahasiswa.

\section{HASIL PENELITIAN}

Penelitian ini menghasilkan paket pembelajaran Filsafat Pendidikan Islam berbasis berpikir kritis, panduan dosen, dan panduan mahasiswa. Paket yang dikembangkan terdiri atas: (1) Konsep dasar filsafat pendidikan Islam, (2) Hakikat manusia, Tuhan, dan alam dalam perspektif al-Qur'an serta implikasinya bagi pendidikan Islam, (3) Hakikat sistem pendidikan Islam (tujuan, metode, kurikulum, pendidik, subjek didik, lingkungan pendidikan); (4) Problematika dan reformulasi pendidikan Islam. Kerangka isi masingmasing paket terdiri atas: (a) tujuan instruksional umum, (b) tujuan instruksional khusus (c) media dan metode pembelajaran, (d) uraian materi ajar, (e) rangkuman, (f) latihan, (g) tes mandiri, (h) kunci jawaban, (i) umpan balik dan tindak lanjut, (j) sumber rujukan. Paket dikembangkan untuki mahasiswa Fakultas Ilmu Tarbiyah dan Keguruan (FITK) IAIN Mataram dan digunakan selama satu semester. Pengembangan dilakukan mengikuti langkah-langkah desain Dick and Carey dan penyempurnaan model Suparman dengan tahapantahapan sebagai berikut: (1) pengembangan draf awal berupa paket pembelajaran, panduan dosen, dan panduan mahasiswa. (2) uji kelayakan teoretik melalui validasi konseptual oleh 2 orang ahli materi, 2 orang ahli desain, dan 1 orang ahli bahasa. Masukkan dari 5 orang ahli tersebut digunakan untuk merevisi produk yang dikembangkan. (3) uji coba pada pengguna produk, yaitu uji coba perorangan pada 5 orang mahasiswa untuk melihat keterbacaan, kemenarikan, dan kemampuan produk memotivasi belajar mahasiswa. uji coba kelompok kecil pada 9 orang mahasiswa, dan uji coba kelompok besar pada 35 orang mahasiswa. Dalam proses uji coba tersebut mahasiswa memberikan penilaian terhadap produk yang dikembangkan. (4) uji efektivitas produk.

\section{Kelayakan Model}

Untuk menentukan kelayakan model dilakukan uji kelayakan model secara teoretis maupun empiris. Uji kelayakan teoretik dilakukan untuk menilai produk yang dikembangkan dari sisi konsep, yaitu kelayakan dalam aspek isi atau materi pembelajaran dan kelayakan dalam aspek metode dan desain pembelajaran. Sedangkan uji kelayakan empiris dilakukan dengan uji coba model yang telah dikembangkan pada calon pengguna di lapangan. Proses uji coba empirik dilakukan melalui uji perorangan (one to one), uji coba kelompok kecil, dan uji kelompok besar.

Uji kelayakan teoretik dilaksanakan dengan cara meminta tanggapan ahli materi dan ahli desain pembelajaran tentang produk yang dikembangkan. Data dan analisis angket tentang tanggapan ahli materi menunjukkan bahwa produk yang dikembangkan memiliki kelayakan teoretik yang sangat kuat, yaitu mencapai rata-rata $91 \%$. Sebaran kelayakan tersebut dapat digambarkan dalam histograf pada Gambar 4 berikut ini.

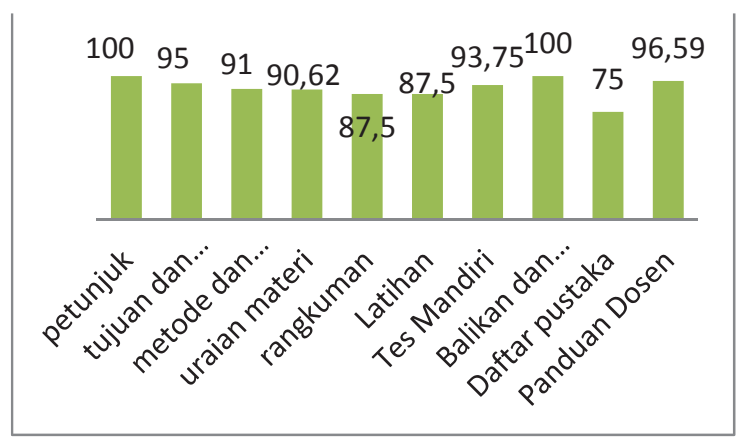

\section{Keterangan:}

- $80-100 \%$ : Sangat layak, tidak perlu direvisi.

- $66-80 \%$ : Layak, tidak perlu direvisi.

- $56-65 \%$ : Kurang layak, perlu direvisi.

- $0-55 \%$ : Sangat kurang layak, perlu direvisi (Arnold, 1999)

Gambar 4 Kelayakan Materi menurut Ahli Media.

Berdasarkan data pada gambar di atas dapat dijelaskan bahwa 90\% komponen yang dikembangkan masuk dalam kategori sangat layak, sedangkan 10 $\%$ masuk dalam kategori layak. Komponen yang 
Selain melibatkan mahasiswa dalam proses dan evaluasi hasil, indikator pembelajaran yang baik juga adalah pembelajaran yang menggunakan multi metode, multi media, dan multi sumber belajar. Pandangan ini didukung oleh banyak teori belajar. Salah satu di antaranya adalah teori belajar kognitivisme. Menurut kognitivisme belajar adalah hasil usaha individu dalam memaknai pengalamanpengalamannya yang berkaitan dengan dunia di sekitarnya(Jamaris, 2010:173). Ini berarti, dosen tidak boleh terpaku hanya menjadikan informasi yang dimilikinya sebagai satu-satunya sumber belajar bagi mahasiswa. Sebaliknya, mahasiswa harus difasilitasi dan dimotivasi agar belajar dengan mengguna multi sumber dan media pembelajaran, termasuk dalam hal ini belajar dengan menggunakan alam semesta sebagai sumber belajar (QS.A1Ghasyiah: 17-20). Penggunaan multi sumber sebagai media pembelajaran sangat penting dalam mewujudkan tujuan pembelajaran, karena fungsi utama media pembelajaran adalah alat bantu yang turut mempengaruhi iklim, kondisi, dan lingkungan belajar yang ditata dan dicipta oleh dosen (Arsyad, 2011: 18).

Belajar berbasis multi sumber dan media akan mengantarkan mahasiswa untuk berada pada suasana belajar yang alamiah di mana mahasiswa bebas mengekspresikan dirinya dalam menggali pengetahuan, keterampilan, dan sikap sesuai dengan tujuan pembelajaran yang telah ditetapkan. Pembelajaran yang demikian didukung juga oleh teori belajar konstruktivisme. Teori ini berpendapat belajar pada hakikatnya adalah proses mengkonstruk pengetahuan melalui keterlibatan fisik dan mental mahasiswa secara aktif dalam upaya menemukan pengetahuan, konsep, kesimpulan, bukan merupakan kegiatan mekanistik untuk mengumpulkan informasi dan fakta (Aunurrahman, 2009:18-19). Seluruh pengetahuan, menurut konstruktivisme, merupakan konstruksi manusia yang dihasilkan dari interaksi sosial (Gredler, 2009: 21-22).Kunci pembelajaran sukses adalah pada strategi pembelajaran yang menjamin terciptanya sinergi antara komponenkomponen kunci pembelajaran dalam mendukung ketercapaian tujuan belajar mahasiswa. Komponenkomponen tersebut adalah mahasiswa, dosen, waktu, sumber belajar, fasilitas, dan tujuan pembelajaran (Oliva, 2004: 349).

Pendekatan pembelajaran berbasis berpikir kritis perlu dihadirkan untuk memposisikan kembali pembelajaran filsafat pendidikan Islam pada posisi yang sebenarnya. Pembelajaran berbasis berpikir kritis, secara konseptual, menjamin terciptanya keterbukaan, partisipasi, dan kesiapan berbagi ruang dalam pembelajaran antara dosen dengan mahasiswa. Skenario pembelajaran berbasis berpikir kritis dibangun atas kekuatan observasi, bertanya, eksperimen, evaluasi, pengambilan keputusan, internalisasi, dan refleksi.

Pengembangan penting dilakukan untuk memperkenalkan kepada dosen strategi pembelajaran baru yang dapat meningkatkan performance dosen dalam pembelajaran dan membantu dosen menyiapkan bahan pembelajaran yang dibutuhkan dan sesuai karakteristik mahasiswa. Perbaikan kualitas performance dosen dilakukan dengan cara menyusun panduan pembelajaran untuk dosen, yang berisi tujuan, metode, media, materi, evaluasi, dan sumber pembelajaran. Sedangkan perbaikan perangkat pembelajaran diarahkan untuk menghasilkan perangkat berupa silabus dan rencana pelaksanaan pembelajaran, serta bahan ajar. Produk yang dihasilkan diharapkan mampu mewujudkan proses, hasil belajar dan pembelajaran yang efektif, efisien, dan menarik.

\section{METODE PENELITIAN}

Penelitian dan pengembangan ini sengaja dihadirkan untuk menjawab kebutuhan terhadap pentingnya pemikiran kritis dimiliki oleh mahasiswa dalam pembelajaran Filsafat Pendidikan Islam. Teori utama yang digunakan dalam proses penelitian adalah teori Gall sedangkan dalam proses pengembangan adalah teori Dick and Carey (2009:6-8). Data-data kualitatif dikumpulkan dengan metode wawancara dan observasi serta dianalisis secara deskriptif. Sedangkan data-data kuantitatif dikumpulkan dengan metode angket dan dianalisis secara statistik deskriptif dengan menggunakan persentase.

Proses pengembangan dilakukan dengan mengacu pada 10 langkah rinci dan sistematis model Dick and Carey, yaitu: (1) identifikasi tujuan pembelajaran dan menulis tujuan pembelajaran umum, (2) analisis instruksional, (3) identifikasi perilaku dan karakteristik awal mahasiswa, (4) merumuskan tujuan instruksional khusus, (5) mengembangkan instrumen penilaian, (6) mengembangkan strategi instruksional, (7) memilih 
alasan yang melatarinya. Sedangkan hasil belajar yang minim ditunjukkan oleh lemahnya kemampuan mahasiswa dalam menjawab pertanyaan -pertanyaan yang bernuansa analisis, sintesis, dan evaluasi, serta rendahnya rasa ingin tahu, kemampuan berfikir terbuka, dan pengambilan keputusan.

Pembelajaran merupakan proses interaksi dosen dengan mahasiswa dan dengan sumber belajar (Rusman, 2013:3) Proses tersebut tidak boleh direduksi menjadi proses interaksi satu arah antara dosen dengan mahasiswa, di mana mahasiswa berada pada posisi pasif sedangkan dosen pada posisi aktif. Pembelajaran pada Mata Kuliah Filsafat Pendididkan Islam harus menghadirkan proses yang multi arah, sebagaimana tersaji pada Gambar 1.

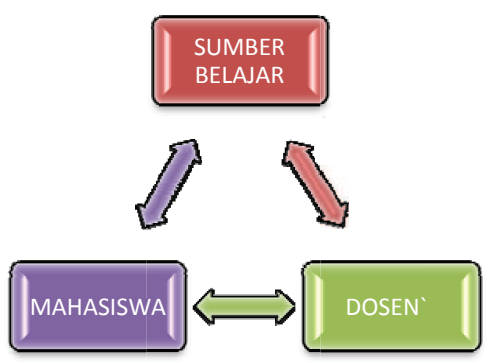

Gambar 1. Hubungan Mahasiswa, Dosen dan Sumber Belajar

Pola hubungan dosen-mahasiswa-sumber belajar merupakan variabel penting yang menentukan efektivitas, efisiensi, dan kemenarikan pembelajaran. Agar tujuan pembelajaran filsafat pendidikan Islam tercapai secara efektif dan efisien, maka paradigma belajar dan pembelajaran harus dirubah dari paradigma konvensional ke paradigma modern. Perbedaan utama kedua paradigma tersebut menurut Rusman (2012: 45-46) adalah, pada paradigma pertama pembelajaran lebih berorientasi dosen, sedangkan pada paradigma modern pembelajaran lebih berorentasi mahasiswa, pada paradigma ini mahasiswa adalah subjek utama pembelajaran.

Pembelajaran menurut paradigma ini adalah upaya dosen dalam membelajarkan mahasiswa. Pembelajaran modern memperlihatkan adanya hubungan yang jelas antar komponen dalam pembelajaran yang sangat bervariasi, yaitu hubungan antar tujuan pembelajaran, bahan pembelajaran, media pembelajaran, strategi pembelajaran, dan evaluasi pembelajaran. Komponen-komponen tersebut saling mengandaikan satu dengan lain dalam pengelolaan mahasiswa. Fungsi dosen dalam paradigma pembelajaran modern adalah merencanakan dan mengelola komponen-komponen tersebut untuk disesuaikan dengan karakteristik mahasiswa. Hubungan antar komponen pembelajaran dapat dilihat pada Gambar 2.

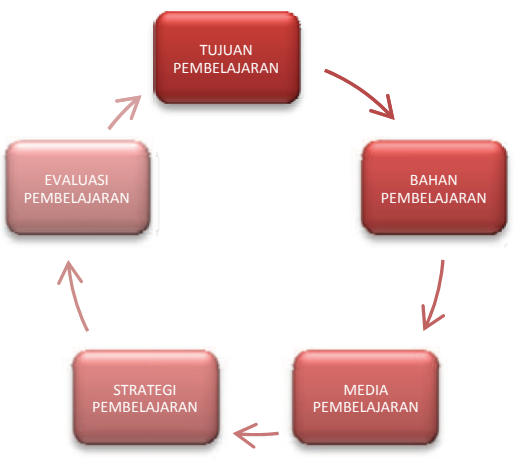

Gambar 2: Hubungan Antar Komponen Pembelajaran

Peran dosen dalam pembelajaran tidak hanya mengajar, melainkan membelajarkan mahasiswa agar mau belajar. Pembelajaran yang baik dalam perspektif paradigma pembelajaran modern adalah pembelajaran yang dapat melibatkan mahasiswa dalam proses dan evaluasi belajar. Keterlibatan dalam proses, bermakna mahasiswa memanfaatkan fasilitas sarana prasarana pembelajaran yang disiapkan dosen berupa bahan, media, stategi, dan evaluasi untuk menemukan sendiri pengetahuan, keterampilan, dan sikap yang diinginkan dalam belajar. Fungsi dosen hanya sebagai fasilitator, mediator, dan motivator untuk meningkatkan peranan mahasiswa dalam berinteraksi dan memanfaatkan komponenkomponen pembelajaran yang sudah disiapkan. Mahasiswa sebagai pusat pembelajaran diilustrasikan oleh Asyhar (2012: 6) dalam gambar 3.

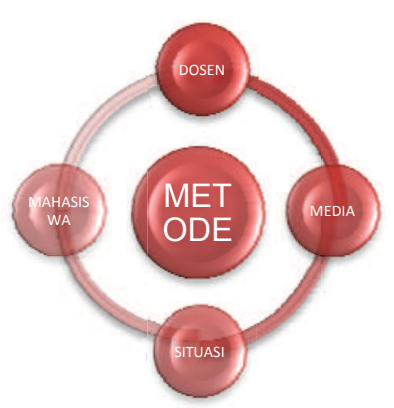

Gambar 3 Komponen yang menentukan efektivitas proses pembelajaran 
mahasiswa dari cara berpikir yang salah menuju cara berpikir yang benar dalam menatap realitas kehidupan sosial, politik, dan agama, yang makin berat dan kompleks. Sebagai generasi pelanjut dan pemimpin masa depan, mahasiswa perlu dibekali kemampuan intelektual, emosional, spiritual, dan sosial yang bermutu tinggi agar bertahan hidup dalam perubahan, pertentangan, ketidakmenentuan, ketidakpastian, dan kerumitan kehidupan global yang penuh resiko (Tilaar,2004:19). Menanamkan kemampuan berpikir kritis di samping penguasaanpenguasan konsep ilmu pengetahuan merupakan cara ampuh dalam membantu mahasiswa tetap eksis dalam pergulatan global yang penuh kompetitif. Berpikir kritis merupakan kompetensi akademis yang hampir sama pentingnya dengan kompetensi membaca dan menulis. Tanpa berpikir kritis, pendidikan tinggi lebih merupakan latihan ketahanan dari pada pendidikan (Zuchdi, 2010: 124).

Kemampuan kritis membantu mahasiswa selama di bangku kuliah dan di luar kuliah. Di bangku kuliah, kemampuan tersebut membantu mahasiswa lebih mudah memahami apa yang dibaca, apa yang ditulis, dan apa yang dilakukan bersama mahasiswa lainnya (Anonim, 2008: 7). Di luar perkuliahan, kemampuan tersebut menolong mahasiswa mengatasi beragam tantangan kehidupan personal dan karier (Event, 2013: 139). Kemampuan kritis merupakan aset tanpa wujud yang menjadi keunggulan bersaing bagi seseorang (Nawawi,2012:25), menjadi arah baru pembelajaran abad ke 21 yang harus dimiliki subjek belajar agar mereka cerdas, kompetitif, dan sanggup memecahkan persoalan yang cenderung global (Sutrisno,2012:3).

Duron(2006:161)menggambarkanberpikirkritis sebagai kemampuan menganalisis dan mengevaluasi informasi. Seorang pemikir kritis selalu berupaya mengenal permasalahan dengan baik, menformulasi permasalahan secara jelas, mengumpulkan informasi yang relevan, menggunakan ide-ide abstrak, berpikir terbuka, dan mampu berkomunikasi efektif dengan orang lain. Proses berpikir kritis meliputi dua langkah besar yakni melakukan proses berpikir nalar (reasoning) dan pengambilan keputusan/ pemecahan masalah (deciding/ problem solving). Oleh karena itu, kegiatan berpikir kritis terdiri dari merumuskan masalah, menganalisis, memecahkan masalah, menyimpulkan, dan mengevaluasiJafri (2012:3). Kemampuan tersebut dapat ditumbuh-kembangkan dengan cara memberi ruang yang sebesar-besarnya kepada mahasiswa untuk mempertanyakan apa yang didengar dan dilihat, dilanjutkan dengan bertanya mengapa dan bagaimana tentang hal tersebut, mengumpulkan bukti-bukti kuat berupa data dan fakta sebelum akhirnya menyimpulkan sesuatu yang dipelajari.

Kemampuan kritis merupakan produk belajar, terutama belajar berbasis pembiasaan dan pengkondisian. Kemampuan tersebut dapat ditumbuh kembangkan melalui semua mata kuliah di perguruan tinggi, terutama mata kuliah filsafat. Mata kuliah filsafat menempatkan berpikir kritis sebagai metode pendekatan pembelajaran (Ahmadi, 2013: 22). Filsafat dan berpikir kritis memiliki hubungan yang sangat erat, pada saat dosen membelajarkan filsafat, maka saat itu dosen memperkenalkan berpikir kritis, begitu pula sebaliknya (Pecorino, 1987:141). Filsafat dalam filsafat pendidikan Islam berposisi sebagai metode berpikir. Proses pembelajaran filsafat pendidikan Islam bukan diarahkan untuk menghafal hasil pemikiran manusia masa lalu tentang pendidikan Islam, akan tetapi berpikir mendalam, sistematis, dan universal tentang hakikat pendidikan Islam itu sendiri sehingga bisa dihasilkan wacana dalam bentuk alternatif baru pendidikan Islam yang dapat ditawarkan untuk menjadi problemsolver pendidikan Islam masa depan (Thoib, 2013).

Mata kuliah filsafat pendidikan Islam, secara konseptual, merupakan mata kuliah yang banyak mengandung masalah dan memberikan ruang bertanya yang luas kepada mahasiswa. Namun, efek pembelajaran mata kuliah ini dalam meningkatkan kemampuan kritis mahasiswa belum sepenuhnya dirasakan oleh mahasiswa Fakultas Ilmu Tarbiyah dan Keguruan (FITK) IAIN Mataram. Keterbatasan kemampuan dosen dalam merencanakan, melaksanakan, dan mengevaluasi pembelajaran serta kurang tersedianya sumber belajar yang memadai untuk pembelajaran yang lebih baik, menyebabkan minimnya hasil belajar yang dicapai mahasiswa. Keterbatasan kemampuan dosen mengerucut dalam bentuk performance pembelajaran yang monoton, satu arah, dan pola-pola pembelajaran yang belum sesuai dengan paradigma pembelajaran modern yang lebih mementingkan partisipasi aktif mahasiswa (student center) dari pada dominasi dosen dalam pembelajaran (teacher center). Keterbatasan sumber belajar tampak pada rendahnya akses mahasiswa pada sumber belajar yang memadai dengan berbagai 


\title{
Pengembangan Paket Pembelajaran Filsafat Pendidikan Islam Berbasis Critical Thinking
}

\begin{abstract}
Ismail*
Abstract: The research aimed at developing packet on critical thinking based for learning and teaching in islamic education philoshophy. The materials designed by using the Dick and Carey models (2009). The model development steps begins by identify instructional goals, conduct instructional analysis, analyze learner and contexs, write performance objectives, develop assessment instrument, develop instructional strategy, develop and select instructional materials, design and conduct formative evaluation of instructional, revising, and design and conduct summative evaluation. The development process applied expext and empirical validation. Empirical validation conducted three field, one-to-one learner treatment 3 students, small group treatment which is cover 9 students, and large treatment 35 students. The research resulted that packet purposed could be effective on critical thinking learning and teaching in islamic education philosophy.
\end{abstract}

Keywords: critical thinking, development, packet, philoshophy, islamic education.

Abstrak: Penelitian ini bertujuan untuk mengembangangkan paket pembelajaran Filsafat Pendidikan Islam berbasis Berpikir Kritis. Pengembangan dilakukan dengan menggunakan desain instruksional Dick and Cerey (2009). Tahapan-tahapan pengembangan model dimulai dari mengidenfikasi tujuan pembelajaran, dilanjutkan dengan analisis instruksional, analisis peserta didik dan konteks, penulisan tujuan pembelajaran, pengembangan instrumen penilaian, pengembangan strategi instruksional, seleksi dan pengembangan bahan instruksional, desain evaluasi formatif, revisi, dan desain evaluasi sumatif. Proses pengembangan menggunakan validasi ahli dan validasi empiris. validasi empiris menggunakan uji perorangan melibatkan 3 orang mahasiswa, uji kelompok kecil melibatkan 9 orang mahasiswa, dan kelompok besar melibatkan 35 orang mahasiswa. Hasil riset menunjukkan paket pembelajaran filsafat pendidikan Islam berbasis berpikir kritis efektif mewujudkan tujuan pembelajaran.

Kata kunci: penelitian dan pengembangan, model pembelajaran, konseling kelompok, konstruktivistik

\section{PENDAHULUAN}

Perubahan akibat kemajuan iptek menjadi anugrah sekaligus problem bagi manusia modern. Perubahan menghadirkan kemudahan dalam tataran fisik material; akan tetapi, menimbulkan kekhawatiran, ketidakpastian, pertentangan, kecemasan, dan kerumitan dalam tataran psikis. Distorsi moral, sosial, dan spiritual mengintip dan menghantui semua orang, tanpa pandang bulu. Fenomena brutalisme, anarkisme, korupsi, kolusi, dan nepotisme mewabah di seantero sudut kehidupan kota dan desa; saling sikut dan saling sikat antar personal dan antar group dalam satu organisasi atas nama perbedaan suku, agama, golongan merambah seluruh lapisan dari eksekutif, legislatif, hingga dunia kampus. Tidak terkecuali kampus berlabel agama, semisal IAIN. Fenomena tersebut merupakan indikator keterbelakangan serta ketidakmampuan bernalar logis dan bersikap kritis dalam merespon persoalan.

Pendidikan tinggi perlu menyelamatkan

* Ismail, IAIN Mataram, Jl. Lestrai Gg. Manalagi XI No.6 Pejeruk, Ampenan Lombok, NTB. Telepon:08123706275/087865555560,email: ismail_thoib@yahoo.com 
rangkuman, dan latihan. Berdasarkan temuan dari ketiga kelas yang memberikan respon dengan ratarata-rata sangat baik, maka mengindikasikan bahan ajar efisien dan menarik dengan sistematika sesuai konsep dasar dan praktik konseing kelompok, materi yang memadai dan dilengkapi dengan evaluasi dan reflleksi.

Respon Dosen terhadap Pembelajaran Konseling Kelompok Konstruktivistik hasilnya untuk kejelasan rancangan model pembelajaran $(83,34 \%)$ menyatakan sangat jelas dan $(16,67 \%)$ menyatakan jelas. Untuk kejelasan setiap tahapan model menyatakan $(83,33 \%)$ sangat jelas dengan tahapan penggunaan model, sementara (16,66\%) menyatakan jelas dan masih ada yang belum dipahami yaitu tentang penggunaan bagan alirkonseling kelompok. Selanjutnya strategi penilaian pembelajaran yang akan dilaksanakan ada $(66,63 \%)$ menyatakan sangat sesuai dengan karakteristik konseling kelompok. selebihnya $(33,34 \%)$ masih ada bagian yang belum sesuai sehingga memerlukan penjelasan. Adapun bentuk penilaian yang memerlukan penjelasan adalah penilaian praktik konseling kelompok. Keyakinan untuk melaksanakan model menunjukan $(83,33 \%)$ menunjukkan yakin dapat melaksanakan dan selebihnya $(16,66 \%)$ berusaha untuk mencobanya. Kesulitan belum ditemukan karena belum melaksanakan. Komentarnya pembelajaran akan menarik dan menantang, peserta didik akan termotivasi untuk belajar mandiri.

\section{DAFTAR RUJUKAN}

Anita Wolfolk, Educatioan Pyscology. Pearson, Inc. 2007.

Atwi Suparman, Desain Instruksional Modern. Jakarta: Erlangga. 2012.

Borg, Wolter R. \& Meredith D. Gall. Educational Research An Introduction, 7th ed. Boston: Pearson Education Inc, 2003.

Corey Gerald, Marianne Schneider Corey, dan Gerald Corey, Group Prosess and Practice. Australia: Thomson Brooks/Cole, 2006.

Dewantara, Ki Hajar. Bagian I - Pendidikan. Yogjakarta: Majelis Luhur Persatuan TamanSiswa, 1977.

Elaine B. Johnson, Contextual Teaching andLearning. Bandung: Kaifa. 2009.
Gagnon Jr. George W. \& Collay Michelle, Designing for Learning Six in Costructivist Classrooms. California: Corein Press, Inc,2001.

Gladding, Samuel T. Counseling A Comprehensive Profession. Columbus, Ohio: Upper Saddle River. New Yersey, 2004.

Jacobs, ED E. et al. Group Counseling : Strategi and Skills. California: Brook/Cole Publishing Company, 2012.

Panduan Umum Pelayanan Bimbingan dan Konseling pada Satuan Pendidikan Dasar dan Menengah. Semarang: ABKIN, 2013.

Prayitno, Mengatasi Krisis Identitas ProfesiKonselor. Padang: FKIP,2013.

Pusat Penelitian Kebijakan dan Inovasi Pendidikan Badan Penelitian dan Pengembangan, Metode Penelitian Pengembangan, Jakarta: Departemen Pendidikan Nasional. 2009.

Walter Dick, Lou Carey, dan James O Carey, The Systemic Design of Instruction. Boston: Pearson. 2005.

Wolfoofolk, Anita. Educational Psychology. Boston: Person Educational Inc,2007. 
Berdasrkan tabel 6 dapat disimpulkan bahwa produk tersebut dapat meningkatkan hasil belajar peserta didik sehingga layak digunakan dalam proses pembelajaran.

Berikut ini ditampilkan dalam betuk grafik

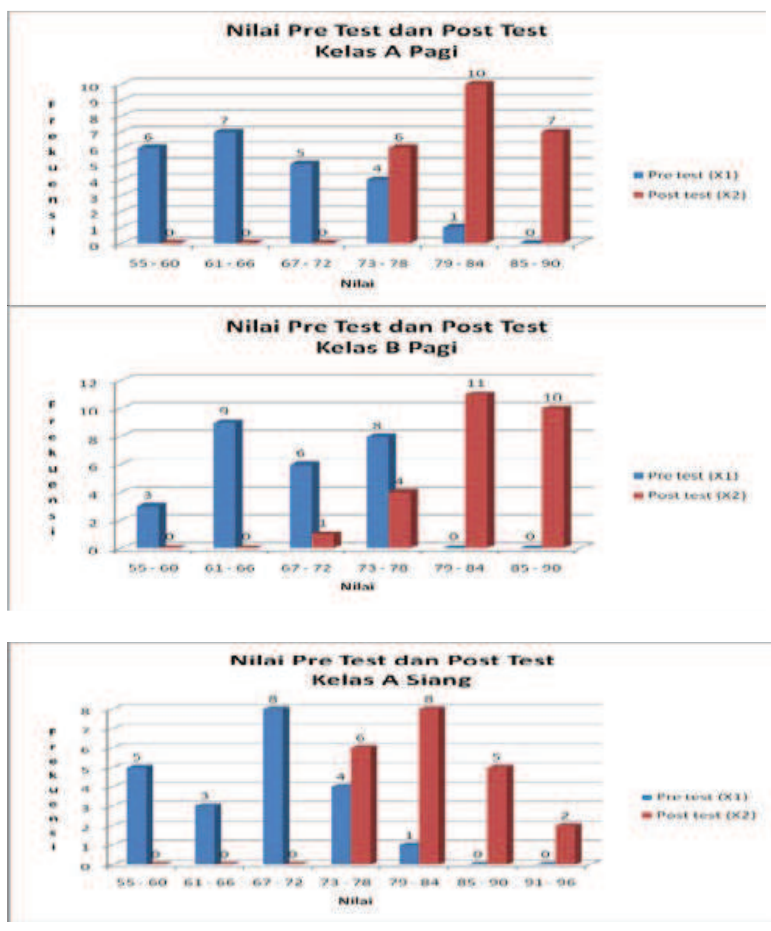

\section{PEMBAHASAN}

Pembelajaran konstruktivistik diterapkan pada KKNI dan kurikulum di Satuan pendidikan. Pelaksanaan pembelajaran masih terdapat banyak kendala, yaitu ketidakjelasan pada perancangan pembelajaran, proses pembelajaran, dan penilaian. Oleh karena itu, pembelajaran tidak efektif dan diperlukan sebuah model pembelajaran yang dapat membantu terlaksanakan pembelajaran dengan baik.

Model pembelajaran konstruktivistik yang dikembangkan pada penelitian ini adalah model yang mengacu pada (1) model konseptual, (2) model prosedural, dan (3) model fisikal.

Secara konseptual, model dikembangkan berdasarkan teori model pembelajaran konstruktivistik dari Gagnon dan Collay (2001:7), bahwa komponen pembelajaran ada enam yaitu (1) situations), (2) (gruopings), (3) bridges, (4) questions, (5) exhibits, (6) reflections. Sedangkan tahapan-tahapan konseling kelompok dari Gladding
(2004: 7), meliputi tahap awal (beginning); (2) tahap transisi (transition); (3) tahap kegiatan (working) dan (4) tahap pengakhiran (termination). Model yang menunjukkan pembelajaran terintegrasi dengan memperhatikan keterampilan, pengetahuan, dan sikap.

Secara prosedural, model pembelajaran pada penelitian ini dikembangkan berdasarkan model Dick dan Carey. Model tersebut merupakan salah satu model prosedural yang menyarankan penerapan desain pembelajaran agar disesuaikan dengan langkah-langkah yang harus ditempuh secara berurutan. Salah satu kelebihan dari model Dick dan Carey adalah adanya tahapan evaluasi formatif dan revisi pada setiap langkah. Model fisikal yang dihasilkan adalah produk berupa Buku bahan ajar, Panduan konseling kelompok, Buku latihan kerja peserta didik untuk praktik konseling kelompok. Setelah mengalami validasi dan uji coba lapangan, diperoleh hasil bahwa model secara efektif dapat meningkatkan hasil belajar peserta didik dalam pembelajaran konseling kelompok.

\section{KESIMPULAN}

Kesimpulan penelitian ini sebagai berikut. (1) Rancangan model pembelajaran konseling kelompok dengan pendekatan konstruktivistik dikembangkan berdasarkan model konseptual, model prosedural, dan model fisikal. (2) Efektivitas pembelajaran konseling kelompok konstruktivistik model fisikal terdiri atas bahan ajar, panduan konseling kelompok, latihan kerja peserta didik. Berikut ini hasil respon peserta didik terhadap bahan hajar menunjukkan kelas A Pagi memberikan respon baik terhadap bahan ajar dengan rata-rata $(86,89 \%)$. Artinya bahan ajar menarik mudah dipahami dengan bahasa sederhana dan sesuai kebutuhan peserta didik. Bahan ajar disusun sesuai dengan kompetensi mata kuliah. Selanjutnya Kelas B Pagi memberikan respon baik dengan rata-rata $(89,19$ $\%$ ), artinya bahan ajar menarik dan efektif untuk digunakan dalam mata kuliah konseling kelompok. Sistematika bahan ajar mempermudah peserta didik dalam menggunakannya, dengan rata- rata $(90,06)$. Sementara Kelas B Siang memberikan respon dengan rata-rata $(91,19)$, artinya bahan ajar sangat menarik dan efektif untuk digunakan, dengan tampilan gambar dan bagan yang sangat membantu peserta didik. Uraian materi sangat sesuai dengan kebutuhan peserta didik dan mudah dipahami, dengan 
Tabel 5. Hasil Validasi Ahli

\begin{tabular}{|l|l|}
\hline \multicolumn{1}{|c|}{ Ahli } & \multicolumn{1}{c|}{ Hasil Validasi } \\
\hline $\begin{array}{l}\text { Ahli Desain } \\
\text { Teknologi } \\
\text { Pendidikan }\end{array}$ & $\begin{array}{l}\text { Relevansi rancangan model } \\
\text { konseptual dengan kebutuhan di } \\
\text { lapangan dinilai baik. Penerapan } \\
\text { konsep baik. Yang masih harus } \\
\text { diperbaiki adalah rancangan model } \\
\text { konseptual berdasarkan } \\
\text { konstruktivistik. Hasil validasi } \\
\text { memberikan skor rata-rata 4,1 }\end{array}$ \\
\hline Ahli Materi & $\begin{array}{l}\text { Hasil validasi ahli materi skor rata- } \\
\text { rata } \\
3,75 \text { (baik) sehingga produk }\end{array}$ \\
\hline Ahli Media & $\begin{array}{l}\text { Skor rata-rata di atas 3,81(baik) } \\
\text { namun masih ada hal-hal yang } \\
\text { harus diperbaiki terutama pada } \\
\text { konsistensi penggunaan font huruf } \\
\text { dan kejelasan ilustrasi gambar } \\
\text { dengan penggnaan warna serta teks. }\end{array}$ \\
\hline
\end{tabular}

\section{Efektivitas Model}

Gambaran efektivitas model akan terlihat dari kebergunaan dan kebermanfaatan model yang dikembangkan. Adapun kebergunaan dan kebermanfaatan model dapat dilihat dari (1) respon subjek uji coba dan (2) hasil belajar yang diperoleh subjek uji coba. Respon subjek uji coba dapat dilihat (a) Uji One to One; (2) Uji Kelompok Kecil, (3) Uji Kelompok lapangan.

\section{a. Uji One to One}

Hasil pendapat subjek uji coba one to one adalah menggunakan tiga orang peserta didik dari tiga kelas masing-masing satu orang dengan kemampuan yang berbeda. Hasilnya sebagai berikut: semua peserta didik tertarik pada produk karena keberadaan secara fisik bahan ajar, panduan dan lembar kerja praktik konseling kelompok terutama tampilan gambar dan warna yang menarik; dua orang peserta didik menyatakan ada gambar yang tidak jelas karena tidak ada teks, seorang peserta didik menyatakan ada kegiatan yang tidak bisa dilakukan karena tidak ada keterangan teks dan gambar.

Masukan dari uji one to one itu digunakan untuk bahan revisi produk. Produk yang sudah direvisi kemudian diuji coba pada uji coba kelompok kecil.

\section{b. Uji Kelompok Kecil}

Hasil uji kelompok kecil adalah dari 9 orang di ambli dari tiga kelas yang berbeda. Uji coba kelompok kecil dikenakan 9 peserta didik di ambil dari tiga kelas yang berbeda dan representatif untuk populasi sarana yang sebenarnya yaitu 3 orang kemampuannya di atas rata-rata dan 3 orang mempunyai kemampuan rata-rata serta 3 orang dibawah rata-rata. Masukan yang diperoleh pada bahan ajar sistematika $(91,67 \%)$, kompetensi $(87,50 \%)$, materi $(87,18 \%)$, evaluasi $(86,81 \%)$. Mengisyaratkan bahan ajar sesuai kebutuhan peserta didik untuk pembelajaran konseling kelompok. Namun masih ada perbaikan tentang gambar, konsistensi huruf dan peletakan teks serta pewarnaan. Sedangkan praktik konseling kelompok, tahap pembentukan (85\%), tahap peralihan $(88,89 \%)$, tahap kegiatan $(85 \%)$ dan tahap pengakhiran $(84,89 \%)$. Menunjukkan bahwa peserta didik telah memahami indikator di setiap tahapan konseling kelompok. Saran bagan alir praktik konseling kelompok dilengkapi panduan pelaksanaan konseling kelompok dengan unsur visi, misi, tujuan, dan prosedur pelaksanaan serta evaluasi.

Masukan dari uji coba kelompok kecil digunakan sebagai bahan revisi produk. Produk yang sudah direvisi akan diuji coba pada uji coba lapangan.

\section{c. Uji Coba Kelompok Lapangan.}

Uji coba kelompok besar dilakukan dengan observasi pembelajaran selama 7 kali pembelajaran. Kelas uji coba adalah kelas A pagi (23) dan B Pagi (26) dan A Siang (21) peserta didik. Indikator tanggapan subjek uji coba sama dengan uji kelompok kecil. Sedangkan uji coba kelompok besar dilakukan pre test dan pos test untuk melihat efektivitas model dari hasil belajar peserta didik. berikut ini rangkuman hasil pre dan pos hasil belajar konseling kelompok.

Tabel 6. Hasil Pretes dan Postes

\begin{tabular}{|c|c|c|c|}
\hline Kelas & Pre Tes & Post Tes & Selisih \\
\hline A Pagi & 66,41 & 81,52 & 15,11 \\
\hline B Pagi & 67,60 & 81,54 & 13,94 \\
\hline A siang & 68,10 & 81,55 & 13,45 \\
\hline
\end{tabular}


Tabel 4. Hasil Observasi Pembelajaran

\begin{tabular}{|l|l|}
\hline \multicolumn{1}{|c|}{ Aspek } & \multicolumn{1}{c|}{ Hasil Penelitian } \\
\hline Kegiatan & $\begin{array}{l}\text { Penyampaian diskripsi mata kuliah } \\
\text { secara umum. Capaian } \\
\text { pembelajaran tidak disampaiakn } \\
\text { dengan jelas, sehingga peserta } \\
\text { didik tidak tau arah mata kuliah. }\end{array}$ \\
\hline $\begin{array}{l}\text { Kegiatan } \\
\text { Inti }\end{array}$ & $\begin{array}{l}\text { Dosen masih banyak } \\
\text { mendominasi dalam } \\
\text { pembelajaran, sehingga } \\
\text { pembelajaran kurang berpusat } \\
\text { pada siswa.. }\end{array}$ \\
\hline Kegiatan & $\begin{array}{l}\text { Belum ada kegiatan merangkum } \\
\text { dan refleksi. Tidak ada penugasan } \\
\text { untuk peserta didik. Pembelajaran } \\
\text { diakhiri dengan doa. }\end{array}$ \\
\hline
\end{tabular}

Berdasarkan tabel 4 tersebut dapat disimpulkan bahwa pembelajaran masih tampak monoton. Pembelajaran kurang menyenangkan dan belum membuat peserta didik aktif membangun gagasan. Masih terdapat kesulitan dan hambatan ketika kegiatan pengungkapan masalah dan pembahasan masalah kegiatan. Pada kegiatan penutup dosen belum mengadakan kegiatan refleksi.

\section{b. Model awal}

Model awal yang secara konseptual dikembangkan berdasarkan model pembelajaran konstruktivistik Gagnon dan Collay (2001:7). Model awal terdiri dari komponen masukan meliputi tujuan pembelajaran, karakteristik peserta didik dan karaktristik mata kuliah konseling kelompok. Sedangkan komponen proses meliputi bahan ajar, enam indikator pembelajaran konstruktivistik masuk dalam unsur strategi pembelajaran dan evaluasi kompetensi kognitif dan keterampilan. Model awal konseptual yang dikembangkan di antaranya bahan ajar, panduan dan lembar kerja peserta didik untuk praktik konselingkelompok.. Model Konseptual

Model ini merupakan hasil revisi dari model awal yang telah mengalami validasi dari desain ahli teknologi pendidikan, ahli materi, dan ahli media. Ahli desain teknologi pendidikan memvalidasi kaitan antara Bahan ajar dan Buku panduan, serta Lembar kerja peserta didik praktik konseling kelompok konstruktivistik. Ahli materi memvalidasi dari kelayakan materi, penyajian materi, kebahasaan, dan grafika. Bentuk fisiknya berupa pembuatan rencana pembelajaran semester (RPS). Ahli media memvalidasi secara khusus tata tulis, desain grafis baik cover maupun isi bahan ajar, panduan dan lembar kerja praktik konseling kelompok dan contoh CD pembelajaran konseling kelompok.

\section{c. Model Draf Akhir}

Model draf akhir pembelajaran konseling kelompok konstruktivistik menampilan model secara utuh yang terdiri atas (1) model konseptual; (2) model prosedural, dan (3) model fisikal.

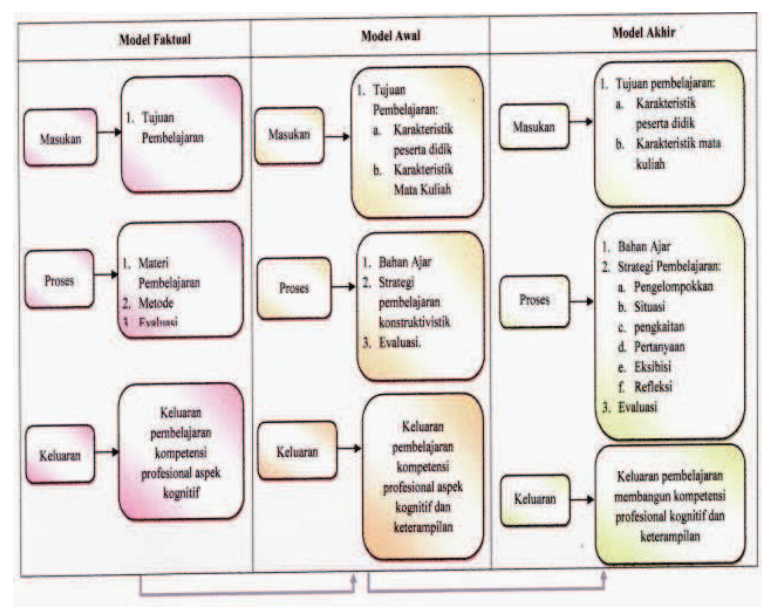

Gambar 1. Model Utuh Pembelajaran Konseling Kelompok Konstruktivistik

\section{Kelayakan Model}

Kelayakan model dirumuskan berdasarkan uji coba pakar, yang terdiri atas desain ahli teknologi pendidikan, ahli materi, dan ahli media. Hasil validasi para pakar adalah sebagai berikut.

Berdasarkan tabel 5 tersebut dapat dijelaskan bahwa masih diperlukan perbaikan pada rancangan model konseptual agar sesuai dengan konsep konstruktivistik. Hasil kelayakan dari ahli materi rata-rata adalah baik. Hal yang harus diperbaiki dari kegrafikan adalah hirarki penggunaan font huruf pada teks pada setiap gambar yang ada dalam bahan ajar. Masukan dari para ahli digunakan sebagai bahan untuk memperbaiki model, sehingga didapat model draf final yang akan diuji coba ke peserta didik. 


\section{Pengembangan Model}

Pada pengembangan model, hasil penelitian dibagi: (a) hasil penelitian pendahuluan; (b) model awal; (c) model konseptual; dan (d) model final.

Berdasarkan tabel 1 dapat disimpulkan bahwa dosen sudah mengenal pembelajaran konstruktivistik. Namun, dosen masih perlu diberi pemahaman tentang perancangan pembelajaran konstruktivistik yang sistemik dan sistematis.

Berdasarkan tabel 1 dapat disimpulkan bahwa dosen sudah mengenal pembelajaran konstruktivistik. Namun, dosen masih perlu diberi pemahaman tentang perancangan pembelajaran konstruktivistik yang sistemik dan sistematis.

Pedalaman hasil kuesioner dilengkapi dengan wawancara dengan peserta didik. Berikut adalah rangkuman hasil wawancara.

Tabel 2. Hasil Wawancara dengan Peserta Didik

\begin{tabular}{|c|l|l|}
\hline No & \multicolumn{1}{|c|}{ Indikator } & \multicolumn{1}{|c|}{ Hasil Penelitian } \\
\hline 1 & $\begin{array}{l}\text { Capaian } \\
\text { Pembelajaran }\end{array}$ & $\begin{array}{l}\text { Deskripsi masih umum, } \\
\text { belum menyampaikan } \\
\text { tagihan mata kuliah dan } \\
\text { capaian pembelajaran untuk } \\
\text { lulusan mata kuliah konseling } \\
\text { kelompok. }\end{array}$ \\
\hline 2 & $\begin{array}{l}\text { Penyajian materi } \\
\text { Pembelajaran }\end{array}$ & $\begin{array}{l}\text { Perancangan pembelajaran } \\
\text { disusun tidak dilakukan } \\
\text { refleksi, revisi dan evaluasi. }\end{array}$ \\
\hline 3 & $\begin{array}{l}\text { Metode } \\
\text { pembelajaran }\end{array}$ & $\begin{array}{l}\text { Peserta didik belum } \\
\text { dioptimalkan } \\
\text { mengembangkan gagasan, } \\
\text { masih berpusat pada } \\
\text { aktivitas dosen. }\end{array}$ \\
\hline 4 & $\begin{array}{l}\text { Ketersediaan } \\
\text { Perangkat } \\
\text { Pembelajaran }\end{array}$ & $\begin{array}{l}\text { Perangkat bahan-bahan } \\
\text { pembelajaran belum tersedia } \\
\text { berupa panduan pelaksanaan } \\
\text { konseling kelompok, bahan } \\
\text { ajar dilengkapi lembar } \\
\text { kegiatan peserta didik. }\end{array}$ \\
\hline 5 & $\begin{array}{l}\text { Evaluasi } \\
\text { Pembelajaran } \\
\text { Mengukur kompetensi } \\
\text { untelektual, bentuk tes } \\
\text { uraian. }\end{array}$ \\
\hline
\end{tabular}

Berdasarkan Tabel 2 dapat disimpulkan bahwa pembelajaran berpusat pada dosen. Aktivitas peserta didik dalam pembelajaran konseling kelompok masih kurang. Dosen belum menyusun rancangan pembelajaran semester dengan sistemik dan sistematis. Pelaksanaan pembelajaran belum menggunakan pendekatan konstruktivstik. Penilaian aspek kognitif belum mengukur praktik konseling kelompok. Untuk itu diperlukan seperangkat pembelajaran yang dapat mempermudah peserta didik dalam belajar.

Hasil wawancara dengan dosen dirangkum seperti terdapat pada tabel 3 .

Tabel 3. Hasil Wawancara dengan Dosen

\begin{tabular}{|c|l|l|}
\hline No & \multicolumn{1}{|c|}{ Indikator } & \multicolumn{1}{c|}{ Hasil Penelitian } \\
\hline 1 & $\begin{array}{l}\text { Capaian } \\
\text { Pembelajaran }\end{array}$ & $\begin{array}{l}\text { Dosen sudah mengetahui } \\
\text { pembelajaran } \\
\text { konstruktivistik. Namun, } \\
\text { belum optimal dilakukan } \\
\text { dalam pembelajaran } \\
\text { konseling kelompok, }\end{array}$ \\
\hline 2 & $\begin{array}{l}\text { Penyajian Materi } \\
\text { Konseling } \\
\text { Kelompok }\end{array}$ & $\begin{array}{l}\text { Dosen sudah dapat membuat } \\
\text { RKP, tetapi belum membuat } \\
\text { rancangan yang }\end{array}$ \\
\hline 3 & $\begin{array}{l}\text { Metode } \\
\text { Pembelajaran }\end{array}$ & $\begin{array}{l}\text { Pembelajaran masih banyak } \\
\text { berpusat pada dosen. }\end{array}$ \\
\hline 4 & $\begin{array}{l}\text { Ketersediaan } \\
\text { Perangkat } \\
\text { Pembelajaran }\end{array}$ & $\begin{array}{l}\text { Belum tersedia dan } \\
\text { membutuhkan perangkat } \\
\text { pembelajaran yang dapat } \\
\text { mempermudah peserta didik } \\
\text { belajar. }\end{array}$ \\
\hline 5 & Evaluasi & $\begin{array}{l}\text { Penilaian ketuntasan belajar } \\
\text { belum dipahami. }\end{array}$ \\
\hline
\end{tabular}

Berdasarkan tabel 3 dapat disimpulkan bahwa dosen masih belum memahami secara maksimal tentang pembelajaran konstruktivistik. Dosen juga belum membuat rancangan pembelajaran secara sistemik dan sistematis. Oleh karena itu, masih memerlukan perangkat pembelajaran yang dapat mempermudah peserta didik belajar.

Hasil kusioner dan wawancara dilengkapi dengan observasi pembelajaran di kelas. Data pembelajaran di kelas terdiri atas (1) kegiatan pembukaan, (2) kegiatan inti, (3) kegiatan penutup. Hasil observasi pembelajaran dapat dirangkum pada tabel berikut. 
$R$ and $D$ diarahkan pada pengembangan produk yang efektif bagi keperluan pembelajaran dan merupakan penelitian terapan. Untuk perbaikan (what works better) daripada kemengapaan (why), dan mementingkan kegunaannya dalam pendidikan (Gall, dkk, 2007: 186 - 187).

Model Dick dan Carey memiliki tahapantahapan sebagai berikut (1) mengidentifikasi tujuan pembelajaran; (2) melaksanakan analisis pem- belajaran; (3) mengidentifikasi tingkah laku dan karakteristik siswa; (4) merumuskan tujuan performansi; (5) mengembangkan butir tes dan acuan patokan; (6) mengembangkan strategi pembelajaran; (7) mengembangkan materi pembelajaran; (8) mendesain dan melaksanakan evaluasi formatif; (9) merevisi bahan pembelajaran, (10) mendesain dan melaksanakan evaluasi sumatif. Penelitian ini sampai pada 8 yaitu evaluasi Formatif. Berikut ini langkah-langkah penelitian: (1) Tahap Pra Pengembangan: langkah satu: penelitian pendahuluan dengan analisis kebutuhan dan studi literatur. Langkah dua; melakukan perencanaan model pembelajaran. Langkah ketiga: Pengembangan draf model, pengembangan draf bahan ajar dan pengembangan draf evaluasi. (2) Tahap Pengembangan Model: Validasi ahi desain pembelajaran, ahli materi, ahli media dan dosen pengampu mata kuliah. Lanjut revisi draf model berdasarkan masukan para ahli. (3) Tahap Uji Coba Evaluasi dan Revisi. Meliputi langkah 4: Uji coba lapangan awal. Langkah 5: Revisi ptoduk hasil uji coba awal. Langkah lima: Revisi produk hasil uji coba awal. Langkah enam: Uji coba lanjutan dan evaluasi.

Prosedur pengumpulan data yang di- gunakan dalam penelitian pendahuluan adalah : 1) observasi, 2) angket, 3) wawancara, dan 4) studi dokumentasi. Pada tahap uji coba peneliti menggunakan angket, wawancara, dan observasi. Analisis data yang digunakan adalah adalah kualitatif dan kuantitatif. Analisis data kualitatif dilakukan melalui penafsiran secara langsung untuk menyusun kesimpulan. Data kuantitatif dilakukan dalam proses uji coba untuk melihat persentase respon subjek uji coba. Pada uji coba lapangan dilakukan analisis data kuantitatif untuk melihat efektivitas penggunaan model terhadap penguasaan materi pembelajaran konstruktivistik dengan mencari selisih antara hasil pre test dan post test. Proses analisis secara statistik dilakukan dengan uji-t untuk mengetahui efektivitas model pembelajaran konseling kelompok konstruktivistik terhadap hasil belajar sesudah dilakukannya proses pembelajaran.

Tahapan pengembangan model terdapat (1) model konseptual, (2) model prosedural, dan (3) model fisikal. Model konseptual adalah model yang bersifat analitis, yang menyebutkan komponenkomponen produk, menganalisis komponen secara rinci dan menunjukkan hubungan antar komponen yang akan dikembangkan. Model prosedural adalah model yang bersifat deskriptif, menunjukkan langkah yang harus diikuti untuk menghasilkan produk. (Pusat Penelitian Kebijakan dan Inovasi Pendidikan Badan Penelitian dan Pengembangan, 2008: 8-9). Model fisikal adalah model dalam bentuk fisik.

\section{HASIL PENELITIAN DAN PEMBAHASAN}

Hasil penelitian meliputi hasil dari (1) Pengembangan model, (2) Kelayakan model, dan (3) Efektivitas model.

\begin{tabular}{|c|c|c|}
\hline No & Indikator & Hasil Penelitian \\
\hline 1 & $\begin{array}{l}\text { Pengertian } \\
\text { Capaian } \\
\text { Pembelajaran }\end{array}$ & $\begin{array}{l}\text { Pemahaman masih kurang } \\
\text { tentang pembelajaran } \\
\text { dengan pendekatan } \\
\text { konstruktivistik, tujuan } \\
\text { pembelajaran dan tagihan } \\
\text { mata kuliah kurang } \\
\text { dipahami. }(29,35 \%)\end{array}$ \\
\hline 2 & $\begin{array}{l}\text { Penyajian } \\
\text { Materi } \\
\text { Pembelajaran } \\
\text { Konseling } \\
\text { Kelompok }\end{array}$ & $\begin{array}{l}\text { Materi pembelajaran } \\
\text { konstruktivistik kurang } \\
\text { dipahami oleh responden } \\
\text { diantaranya dinamika } \\
\text { kelompok, struktur } \\
\text { kelompok, tahapan } \\
\text { konseling kelompok dan } \\
\text { pendektaan kelompok. } \\
\text { penyajian materi kurang } \\
\text { sistematis. }(25.5 \%)\end{array}$ \\
\hline 3 & $\begin{array}{l}\text { Metode } \\
\text { Pembelajaran }\end{array}$ & $\begin{array}{l}\text { Pembelajaran } \\
\text { berpusat pada } \begin{array}{r}\text { masih } \\
\text { dosen. } \\
\text { Ceramah }\end{array} \\
\text { mendominasi }(10,5 \%)\end{array}$ \\
\hline 4 & $\begin{array}{l}\text { Ketersediaan } \\
\text { Perangkat } \\
\text { Pembelajaran }\end{array}$ & $\begin{array}{l}\text { Responden memerlukan } \\
\text { bahan- Bahan pembelajaran } \\
\text { berupa bahan ajar, panduan } \\
\text { konseling kelompok dan } \\
\text { lembar kerja untuk praktik } \\
\text { konseling kelompok. } \\
(20,15)\end{array}$ \\
\hline 5 & $\begin{array}{l}\text { Evaluasi } \\
\text { Pembelajaran }\end{array}$ & $\begin{array}{l}\text { Evaluasi kognitif belum ada } \\
\text { refleksi diakhir } \\
\text { pembelajaran }(15,40)\end{array}$ \\
\hline
\end{tabular}

Tabel 1. Hasil Pendapat Responden dalam Penelitian Pendahuluan 